Representação Política e Protecionismo: Uma Avaliação dos Incentivos Eleitorais Sobre os Níveis de Proteção Comercial em Países Democráticos

\author{
Flavio Leão Pinheiro
}

TESE APRESENTADA

AO

INSTITUTO DE RELAÇÕES INTERNACIONAIS (IRI)

DA

UNIVERSIDADE DE SÃo PAULO

PARA

OBTENÇÃO DO TÍTULO

$\mathrm{DE}$

DOUTOR EM CIÊNCIAS

Programa: Relações Internacionais

Orientadora: Janina Onuki

Durante o desenvolvimento deste trabalho o autor recebeu auxílio financeiro do CNPq e da FAPESP

São Paulo, Dezembro de 2013 


\title{
Representação Política e Protecionismo: Uma Avaliação dos Incentivos Eleitorais Sobre os Níveis de Proteção Comercial
}

\author{
Esta é a versão original da tese elaborada pelo \\ candidato (Flávio Leão Pinheiro), tal como \\ submetida à Comissão Julgadora.
}

Comissão Julgadora:

- Prof. Dr. Janina Onuki (orientadora) - IRI-USP

- Prof. Dr. Amâncio Jorge Silva Nunes de Oliveira - IRI-USP

- Prof. Dr. Adriana Schor - IRI-USP

- Prof. Dr. Octavio Amorim Neto - FGV-RJ

- Prof. Dr. Fernando de Magalhães Papaterra Limongi - DCP-USP 
Aos meus pais. 


\section{Agradecimentos}

Durante o doutorado, que se finaliza com a apresentação desta tese, recebi o apoio de muitas pessoas. Dessa forma, é um grande prazer poder agradecer a todos pelo auxílio prestado das mais diversas maneiras. Primeiramente, agradeço à professora Janina Onuki, orientadora, pela atenção dispensada durante a elaboração deste trabalho e pelo constante incentivo nas mais diversas iniciativas acadêmicas. Além do mais, juntamente com o professor Amâncio de Oliveira, sou grato pela oportunidade de terem aberto as portas do Centro de Estudos das Negociações Internacionais (CAENI) desde a minha chegada a São Paulo. A participação nas atividades do centro, um espaço acadêmico por excelência, composto por pessoas extremamente competentes e dedicadas à vida acadêmica, propiciou-me um ambiente mais do que apropriado para o desenvolvimento de atividades de pesquisa. Agradeço também aos professores Adriana Schor,

Amâncio de Oliveira, Fernando Limongi e Octavio Amorim Neto por terem aceitado o convite para participar da banca examinadora de defesa.

O Instituto de Relações Internacionais (IRI) da Universidade de São Paulo (USP) ofereceu condições favoráveis para o desenvolvimento do doutorado, pois que formado por alunos e pesquisadores dedicados à vida acadêmica. Sou especialmente grato aos professores Daniela Schettini, Maria Antonieta Del Tedesco Lins, Maria Hermínia Tavares de Almeida e Leandro Piquet, com os quais tive contato seja na condição de aluno ou de monitor junto à graduação. Também registro todo o auxílio concedido por meio da secretaria da pós-graduação do IRI-USP pela Giselle de Castro e Maria Elisabete Cardone.

Posso afirmar que o trabalho apresentado se beneficiou muito da experiência que tive como visiting graduate fellow na University of California, San Diego (UCSD) sob supervisão do professor Scott Desposato. Além de ter tido a oportunidade de cursar diversas disciplinas e participar de seminários da área, a troca de experiências com os colegas de Ignacio De Ferrari, Oliver Westerwinter, Simone Gunther e Jorge Fernandes foi sempre enriquecedora. Destaco, também, os comentários pertinentes do professor Lawrence Broz no estágio inicial desde projeto.

Partes desta tese, em distintas etapas de elaboração, foram apresentadas em vários congressos e workshops acadêmicos, como na International Studies Association (ISA), na Southern Political Science Association (SPSA), na American Political Science Association (APSA), no Coase Institute, no CAENI, e no Seminário de Alunos de Pós-graduação do Departamento de Ciência Política (DCP) da USP, em que recebi comentários pertinentes, que foram incor- 
porados ao estudo. Para participar desses eventos, foi essencial o apoio financeiro concedido pela Fundação de Amparo à Pesquisa do Estado de São Paulo (Fapesp), da qual sou bolsista, processo número 2009/12376-0; da Coordenação de Aperfeiçoamento de Pessoal de Nível Superior (Capes); do Conselho Nacional de Desenvolvimento Científico e Tecnológico (CNPq); da Reitoria de Pós-graduação da USP; do IRI-USP.

Aproveito para agradecer aos companheiros de vida acadêmica do IRI-USP, do DCP-USP, do CAENI e do antigo IUPERJ, que foram mais do que colegas e permitiram que esse período de 4 anos fosse o mais agradável possível. Eles estiveram sempre presentes fazendo comentários sobre meus trabalhos; sendo co-autores em outros; revisando e traduzindo artigos; sugerindo e explicando alguns modelos; ou simplesmente estando disponíveis para um café durante à tarde ou longas horas de skype durante as madrugadas: Cícero Krupp da Luz, Flávio Pedroso, Lucas Tasquetto, Ítalo Sposito, Izabela Araújo, Umberto Mignozzetti, Rafael Magalhães, Ivan Fernandes, Gabriel Cepaluni, Gustavo Araújo, Marcelo Vieira e Flávio Carvalhaes.

Por fim, agradeço aos amigos, que, mesmo distantes, estão sempre presentes. E à família, pela confiança, compreensão e afeto; e por todo conforto e segurança que me proporcionou durante o meu doutorado. 
I do think you should think things through theoretically before starting to work, but in the end, for me, sound academic work is mainly about sound empirical testing. (Arend Lipjart, entrevista, 2008)

All research is qualitative; some is also quantitative. Purely quantitative research is an Excel spreadsheet w/o column labels

(Garry King, twitter, 2013)

Not that the story need be long, but it will take a long while to make it short. (Henry David Thoreau, carta, 1857)

Un hombre se propone la tarea de dibujar el mundo. A lo largo de los años puebla un espacio con imágenes de provincias, de reinos, de montañas, de bahías, de naves, de islas, de peces, de habitaciones, de instrumentos, de astros, de caballos y de personas. Poco antes de morir, descubre que ese paciente laberinto de líneas traza la imágen de su cara. (Jorge L. Borges, El Hacedor, 1960) 


\section{Resumo}

PINHEIRO, F. L. Representação Política e Protecionismo: Uma Avaliação dos Incentivos Eleitorais Sobre os Níveis de Proteção Comercial em Países Democráticos. 2013. 118 f. Tese (Doutorado) - Instituto de Relações Internacionais, Universidade de São Paulo, São Paulo, 2013.

As regras eleitorais podem afetar o nível de proteção comercial em países democráticos? Estudos recentes indicam que, no que diz respeito ao protecionismo comercial, as instituições eleitorais importam. No entanto, diante de uma análise mais detalhada da literatura, é possível perceber que não há uma teoria prevalecente e que os resultados apresentados são ainda contraditórios. Nesta tese, objetiva-se resolver esse problema teórico e empírico que envolve representação política e protecionismo comercial testando pressupostos da literatura e apresentando explicações alternativas.

A primeira parte do estudo aborda problema específico que, indiretamente, serviu de incentivo para a segunda etapa. A questão que se busca responder pode ser resumida na seguinte indagação: o tamanho do distrito eleitoral é um bom preditor para as preferências em matéria de política comercial do legislador? A pergunta trata, diretamente, da Constituency Size Assumption, um pressuposto que é amplamente aceito pela literatura de Economia Política Internacional (EPI). De acordo com essa abordagem, quanto maior o distrito, maior a probabilidade de o legislador se mostrar favorável ao livre-comércio, uma vez que ele estaria insulado em relação a grupos de interesses. Em distritos menores, no entanto, legisladores poderiam ser tornar, mais facilmente, reféns de interesses particularistas, fato que resultaria em posições protecionistas. Nesta parte, foi proposto o estudo dos casos brasileiros e chileno, levando em consideração as votações nominais de deputados e senadores. Corroborando os achados da literatura, também não foram encontradas evidências para validar a teoria diante da análise de votos nominais entre os anos de 1995 e 2010, para o Brasil, e entre 1996 e 2006, para o Chile.

Na segunda parte, apresenta-se o modelo Stigler-Peltzman (S-P) de regulação, tal qual formalizado por Chang et al. em Electoral Systems and the Balance of Consumer-Producer Power, como uma possível solução para se entender a relação entre os incentivos gerados pelos sistemas eleitorais e os níveis de proteção comercial em democracias. Após adaptar o modelo para a área de política comercial, este foi testado empiricamente em 37 democracias entre os 
anos de 1995 e 2008, quando se estimou o efeito do nível de responsividade dos sistemas eleitorais - desproporcionalidade eleitoral - sobre o nível de proteção tarifária. Os achados indicam que quanto maior a taxa de proporcionalidade entre entre cadeiras e votos obtidos gerada pelos sistemas eleitorais, maior o nível de proteção que os governantes eleitos irão oferecer aos grupos de interesses, especialmente em democracias não-presidencialistas.

Palavras-chave: política comercial, protecionismo, sistemas eleitorais, desproporcionalidade eleitoral, estudo comparado, estudo de caso. 


\section{Abstract}

PINHEIRO, F. L. Political Representation and Protectionism: Assessing How Electoral Institutions Affect Tariff Levels in Democracies. 2013. 118 f. Tese (Doutorado) - Instituto de Relações Internacionais, Universidade de São Paulo, São Paulo, 2013.

Do electoral rules affect the level of trade protection in democratic countries? Recent studies indicate that, when it comes to trade protection, electoral systems do matter; however, a thorough analysis of the literature unveils the fact that competing theories and mixed findings still prevail. In this dissertation, I intend to solve the empirical and theoretical puzzle involving political representation and trade policy by offering and testing an alternative explanation.

In the first part, I investigate a more specific problem, which, indirectly, was an incentive to develop the second part. The question I attempt to answer is: Does the electoral district size affect legislator's preference in trade policy? The question is related to the Constituency Size Assumption, which is widely accepted in the International Political Economy (IPE) literature. Accordingly, the larger the constituency, the more prone the legislator will be to free trade, given that he will be insulated from special interests. Smaller constituencies, however, would lead to concern for particularistic interests, which would result in a protectionist position. Until recently, few studies have proposed empirical analyses of this relationship, and those who have accomplished the feat of presenting findings that cast doubt on the validity of this assumption, have been restricted to the US Congress. In this section, I test the constituency size theory in Brazil and Chile, contrasting vote preference with the trade policy of Representatives and Senators. I found no evidence of the theory's validity. The empirical analysis is based on rollcall votes from 1995 to 2010 (Brazil) and from 1996 to 2006 (Chile), in which we compared trade-related bills voted in both Houses.

In the second part of this work, I present as an answer to the puzzle the Stigler-Peltzman (S-P) analysis of regulation, formalized by Chang et al. in Electoral Systems and the Balance of Consumer-Producer Power. Adapting their model, I evaluate the effect of electoral institutions on the level of trade protection. More specifically, I analyze 37 democracies from 1995 to 2008 and estimate the effect of electoral systems' level of responsiveness - electoral disproportionality - on trade protection. The findings indicate that the higher the rate of proportionality created by electoral institutions, the greater the level of protection that politicians will provide 
for special interest groups, especially in non-presidential democracies.

Keywords: trade policy, protectionism, electoral systems, electoral disproportionality, crossnational study, case study. 


\section{Sumário}

$\begin{array}{ll}\text { Lista de Abreviaturas } & \text { xv }\end{array}$

Lista de Figuras $\quad$ xvii

Lista de Tabelas $\quad$ xix

1 Introdução $\quad 21$

2 Representação Política e Protecionismo 27

2.1 Por que razão o Sistema Eleitoral $\quad \ldots \ldots$. . . . . . . . . . . . . . . 30

2.1.1 Sistema Eleitoral e Resultados Econômicos . . . . . . . . . . . . . . 30

2.1.2 Sistema Eleitoral e Comércio . . . . . . . . . . . . . . . . . . 34

2.1.3 Testando Hipóteses em Estudos Comparados . . . . . . . . . . . . . . 37

2.2 Discussão . . . . . . . . . . . . . . . . . . . . . . . . . 42

3 Analisando a Constituency Size Assumption Por Meio de Dois Estudos de Caso: Brasil e Chile $\quad \mathbf{4 5}$

3.1 O Caso Brasileiro . . . . . . . . . . . . . . . . . . . . . . 50

3.1.1 Especificação do Modelo e Dados Utilizados . . . . . . . . . . . . . 50

3.1 .2 Resultados . . . . . . . . . . . . . . . . . . 55

3.2 O Caso Chileno . . . . . . . . . . . . . . . . . . . . . . . . 60

3.2.1 Especificação do Modelo e Dados . . . . . . . . . . . . . . . . . 60

3.2 .2 Resultados . . . . . . . . . . . . . . . . . . . . . 64

3.3 Implicações Para Literatura de EPI . . . . . . . . . . . . . . . . . . . . . 67

4 Desproporcionalidade e Proteção Comercial 69

4.1 O Modelo Stigler-Peltzman de Regulação e Barreiras Comerciais . . . . . . . . 70

4.2 Mensurando Desproporcionalidade Eleitoral e Proteção Comercial . . . . . . . 73

4.2.1 Variável Independente Primária: IDE . . . . . . . . . . . . . . . 73 
4.2.2 Variáveis Dependentes: Média Tarifária e Número de Picos Tarifários 77

4.3 Hipóteses, Metodologia e Especificação do Modelo . . . . . . . . . . . . . . . 80

4.3.1 Hipóteses . . . . . . . . . . . . . . . . . . . . . . 80

4.3 .2 Metodologia . . . . . . . . . . . . . . 80

4.3 .3 Especificação . . . . . . . . . . . . . . . . . . 83

4.4 Análise Empírica . . . . . . . . . . . . . . . . . . . 86

4.5 Discussão . . . . . . . . . . . . . . . . . . . . 91

5 Conclusão $\quad 95$

$\begin{array}{lr}\text { A } & 99\end{array}$

$\begin{array}{ll}\text { Referências Bibliográficas } & 105\end{array}$ 


\section{Lista de Abreviaturas}

$\begin{array}{ll}\text { AELC } & \text { Associação Europeia de Livre-comércio } \\ \text { BNT } & \text { Barreiras não tarifárias } \\ \text { CTE } & \text { Consumer Equivalent Tax } \\ \text { DEM } & \text { Democratas } \\ \text { GATT } & \text { General Agreement on Tariffs and Trade } \\ \text { IDE } & \text { Índice de Desproporcionalidade Eleitoral } \\ \text { Mercosul } & \text { Mercado Comum do Sul } \\ \text { OCDE } & \text { Organização para a Cooperação e Desenvolvimento Econômico } \\ \text { OMC } & \text { Organização Mundial do Comércio } \\ \text { PDC } & \text { Partido Democrata Cristão } \\ \text { PMDB } & \text { Partido da Movimento Democrático Brasileiro } \\ \text { PPD } & \text { Partido Pela Democracia } \\ \text { PRSD } & \text { Partido Radical Social Democrata } \\ \text { PPE } & \text { Partidos Pequenos de Esquerda } \\ \text { PPD } & \text { Partidos Pequenos de Direita } \\ \text { PS } & \text { Partido Socialista } \\ \text { PSDB } & \text { Partido da Social Democracia Brasileira (PSDB) } \\ \text { PT } & \text { Partido dos Trabalhadores } \\ \text { PTB } & \text { Partido Trabalhista Brasileiro } \\ \text { RN } & \text { Renovação Nacional } \\ \text { TLC } & \text { Tratado de Livre-comércio } \\ \text { TRIPs } & \text { Trade-Related Aspects of Intellectual Property Rights } \\ \text { UDI } & \text { União Democrática Independência } \\ \text { UCCP } & \text { União de Centro Centro Progressista } \\ \text { UE } & \text { União Europeia } \\ & \end{array}$




\section{Lista de Figuras}

4.1 IDE e Sistemas Eleitorais . . . . . . . . . . . . . . . . . . . . . 75

4.2 IDE em 37 Democracias entre 1995 to $2008 \ldots \ldots \ldots$. . . . . . . . . 76

4.3 Tarifa Média Aplicada . . . . . . . . . . . . . . . . . . . 78

4.4 Número de Picos Tarifários Domésticos . . . . . . . . . . . . . . . . . . . 79

4.5 Efeitos do Termo de Interação sobre Picos Domésticos ～. . . . . . . . . . . . . 90

4.6 Efeitos do Termo de Interação sobre Tarifa Média Aplicada . . . . . . . . . . . 91 


\section{Lista de Tabelas}

3.1 Legislação Relacionada a Comércio - 1995-2009 . . . . . . . . . . . . . . . . 52

3.2 Estatística Descritiva I, Brasil . . . . . . . . . . . . . . . . . . . 53

3.3 Estatística Descritiva II, Brasil . . . . . . . . . . . . . . . . . . . 54

3.4 Resultado Regressão, Brasil I . . . . . . . . . . . . . . . . . . . . . 56

3.5 Resultado Regressão, Brasil II ． . . . . . . . . . . . . . . . . . . . . 57

3.6 Votação Nominal sobre Comércio, Chile (1996-2006) . . . . . . . . . . . . . . 62

3.7 Estatística Descritiva I, Chile . . . . . . . . . . . . . . . . 63

3.8 Estatística Descritiva II, Chile . . . . . . . . . . . . . . . . . . . . 64

3.9 Resultado Regressão, Chile . . . . . . . . . . . . . . . . . . . . . 66

$4.1 \quad$ Estatística Descritiva . . . . . . . . . . . . . . . . . . . 84

4.2 Estatística Descritiva . . . . . . . . . . . . . . . . . . 85

4.3 Resultado Regressão, 1995-2008, (Variável de Interesse: IDE) ． . . . . . . . . 87

4.4 Resultado Regressão, 1995-2008, (Variáveis de Interesse: MAJ e PR) . . . . . 93

A.1 Resultado Regressão, Critério de Seleção Freedom House, 1995-2008 . . . . . 103

A.2 Resultado Regressão, Critério de Seleção Polity IV (+6), 1995-2008 . . . . . 104 


\section{Capítulo 1}

\section{Introdução}

O fato de governantes em países democráticos implementarem políticas protecionistas, que beneficiam um grupo restrito de cidadãos, mesmo sabendo que essas medidas são economicamente ineficientes e que impõem um custo ao bem estar geral, constitui um dos principais temas de estudo de economistas e cientistas políticos. Outro aspecto do mesmo fenômeno que gera igual preocupação é a variação do recurso a tais medidas. Qual seria a explicação para haver grande diferença na aplicação de proteção comercial entre democracias? Fatores econômicos, por si sós, seriam satisfatórios? Ou fatores políticos poderiam ser adicionados à equação? Uma vasta literatura na área de Economia Política Internacional (EPI) aborda a questão, e, apesar já haver um corpo substantivo de conhecimento acumulado, muitas dessas perguntas ainda se encontram em aberto.

A razão de tamanho interesse no tema não repousa, tão-somente, no fato de se tratar de um puzzle teórico em aberto; mas, sobretudo, por serem as políticas protecionistas uma prática frequentemente utilizada, apesar de recriminada, pelos Estados. A corrida em direção ao livrecomércio, tal como anunciada na década de 1990, especialmente em razão da estruturação da Organização Mundial do Comércio (OMC), não se constituiu como um fator inibidor do protecionismo. De fato, houve uma considerável redução da aplicação de barreiras tarifárias e não-tarifárias ao comércio; ao mesmo tempo, o recurso a essas medidas está longe de cair em 
desuso.

A recente estagnação econômica, gerada pela crise financeira nos EUA, deu mostras disso. Mesmo com a presença da OMC, considerada por muitos relativamente eficiente no que diz respeito ao combate ao protecionismo, o think-tank Global Trade Alert apontou que, desde 2009, mais de 400 novas medidas restritivas ao comércio foram postas em práticas por países membros da organização. Mais importante: existe considerável tendência de aumento delas. Os exemplos atuais de seu uso são muitos. Em 2012, o governo brasileiro decidiu impor um aumento de $30 \%$ nos impostos incidentes sobre carros que não tenham ao menos $65 \%$ de componentes nacionais. O episódio se deu em razão da iminência da entrada de empresas automotivas no mercado brasileiro. É notório que países emergentes fazem mais uso de medidas protecionistas; no entanto, exemplos são facilmente encontrados entre os desenvolvidos. Os EUA, por exemplo, impõem tarifa de $127 \%$ aos clips de papel provenientes da China; enquanto o Japão determina tarifa de $778 \%$ para o arroz importado.

Diante desse cenário, cientistas sociais se debruçam sobre o tema para tentar explicar possíveis anomalias, que fogem da aparente racionalidade econômica e política. De modo geral, eles se dividem entre aqueles que buscam dar conta do fenômeno tendo por foco o lado da demanda por proteção, basicamente, a ação de grupos de interesses - e, por esse motivo, essa literatura é conhecida como endogeneous tariff formation ou interest group aproach -; e aqueles que buscam a explicação no lado da oferta da proteção, os governantes, focando as atenções no desenho das instituições políticas domésticas e nos incentivos gerados por estas.

A literatura sobre endogeneous tariff enfatiza o impacto dos grupos de pressão sobre a formulação das políticas comerciais. O nível e a estrutura da proteção, argumentam, são explicados pelas características econômicas e organizacionais dos atores domésticos, que possuem interesses distintos quanto ao livre-comércio. Um pressuposto fundamental dessa abordagem é que alguns grupos estão mais bem posicionados que outros ao articular as demandas junto 
ao Estado. Já a literatura institucional concede mais atenção às variáveis do lado da oferta da proteção, enfatizando as conexões entre os desenhos institucionais e os níveis de proteção comercial. A premissa central desses autores é que o protecionismo é uma concessão que beneficia a poucos, ao passo que o livre-comércio detém o status de bem público, que atende às preferências da maior parte dos cidadãos. Assim, os níveis de proteção tenderão a ser mais baixos em um ambiente no qual políticos tenham incentivos para prover bens públicos no nível nacional e estar insulado de interesses protecionistas.

Apesar de existirem problemas e questões a serem respondidas tanto na literatura sobre grupo de interesses como na de instituições, esta tese se restringe a discutir a segunda, com o foco específico nas instituições eleitorais. Nada obstante o fato de estar bastante claro que as instituições representativas influenciam a formatação de políticas comerciais, ainda resta um alto grau de indefinição nos estudos sobre a matéria. Por essa razão, ao mesmo tempo que se busca testar algumas hipóteses clássicas da literatura, apresenta-se, também, uma explicação alternativa para o papel das instituições eleitorais sobre os níveis de proteção comercial em democracias contemporâneas, com o intuito de acrescentar maior conhecimento à dinâmica em questão. Para essa tarefa, recorre-se a uma variedade de métodos e desenhos de pesquisa.

O ponto central da pesquisa, portanto, é responder a seguinte questão, já por muitos debatida: os sistemas de representação política produzem efeito sobre o nível de proteção comercial em democracias contemporâneas? Se sim, qual seria o mecanismo para explicar essa relação? Para lidar com essas indagações, em um primeiro momento, recorreu-se à abordagem do Modelo Stigler-Peltzman (S-P) de regulação, que informa que, quanto maior a responsividade dos votos em uma eleição democrática, maior a probabilidade de implementação de políticas com viés pró-consumidor, e, consequentemente, menores os níveis de proteção comercial. Em uma segunda etapa da pesquisa, buscou-se analisar os micro-fundamentos de abordagem contraposta, e prevalecente na literatura, a Constituency Size Assumption. 
As evidências encontradas e reportadas ao longo da tese poderiam ser assim resumidas: é possível a afirmar que (1) maiores níveis de responsividade do voto indicariam protecionismo comercial menos acentuado; (2) os efeitos, no entanto, estariam restritos a países não-presidencialistas. Além do mais, (3) confirmando grande parte da literatura, o efeito de sistemas presidencialistas impacta negativamente os níveis de proteção. No que diz respeito aos testes relacionados com o tamanho do distrito e as preferências comerciais de legisladores, (4) não foram encontradas evidências que dessem suporte à teoria.

O documento está organizado da seguinte maneira: o capítulo 2, que segue após essa breve introdução, apresenta uma extensa, mas não exaustiva, revisão da literatura, com foco nos trabalhos que tratam da lado da oferta da proteção comercial. Na análise, detectam-se incongruências nos resultados: apesar de a maior parte dos estudos terem apresentado resultados positivos sobre o efeito das instituições eleitorais, eles são precários e contraditórios. Acreditase que os problemas decorrem, basicamente, da falta de teoria alternativa robusta. No capítulo 3, buscou-se analisar o pressuposto do tamanho do distrito, abordagem que informa a maior parte dos estudos que analisam o impacto dos sistemas de presentação sobre o comércio, em dois países latino-americanos, Brasil e Chile, levando-se em conta votações nominais em matéria comercial. Em ambos, as expectativas iniciais foram confirmadas, corroborando os achados de estudos sobre o caso norte-americano.

No capítulo 4, apresenta-se o modelo S-P de regulação. As hipóteses que decorrem da teoria são testadas em um desenho de pesquisa observacional em painel com 37 países entre os anos de 1995 e 2008. Deixa-se de lado a clássica distinção dicotômica entre sistemas majoritário e proporcional, recorrendo-se à relação entre cadeiras-votos, mensurada por meio do Índice de Desproporcionalidade Eleitoral (IDE). Fazendo uso do IDE, pode-se dar conta da responsividade dos sistemas políticos e testar hipótese central da seção. Por fim, no capítulo 5, apresenta-se resumo e discussão dos principais resultados desta tese. As bases de dados 
referentes às análises empíricas do capítulo 3 e do capítulo 4, juntamente com os respectivos scripts para replicar o trabalho utilizando o pacote estatístico R, estão disponíveis online em https://sites.google.com/site/pinheirof/data. 


\section{Capítulo 2}

\section{Representação Política e Protecionismo}

O presente capítulo apresenta uma revisão crítica dos estudos que abordam o impacto de arranjos institucionais domésticos sobre a política comercial com o objetivo de sistematizar os principais achados da literatura. Apesar de haver um claro consenso sobre a importância do papel das instituições representativas para a definição dos níveis de proteção comercial em democracias, a literatura ainda não conseguiu apresentar resultados empíricos sólidos a esse respeito. Muitos dos problemas poderiam decorrer de imprecisões de mensuração ou outras questões metodológicas. No entanto, acredita-se que o ponto mais relevante seja a ausência de teorias mais robustas para dar conta do fenômeno. Nesse contexto, busca-se contribuir para o acúmulo de conhecimento na área apresentando explicação alternativa, calcada em adaptação ao modelo S-P de regulação.

Antes de entrar na análise da literatura institucional sobre política comercial, entende-se que seria relevante informar um pouco mais sobre o paradigma teórico ao qual esta pesquisa se vincula, assim como apontar de que forma se dá a dinâmica entre sistemas eleitorais e resultados econômicos. Seria importante detectar os principais achados da área e indicar os mecanismos mais comumente utilizados, uma vez que estes são basicamente os mesmos empregados pela literatura do supply side of trade.

No que diz respeito ao primeiro aspecto, segue-se a linha de paradigma atualmente dom- 
inante na área de EPI, denominado Open Economy Politics (OEP) (Lake, 2009). Substantivamente, autores de OEP se debruçam sobre temas clássicos, como preferências tarifárias, taxa de câmbio e política monetária, fluxo de investimento externo, entre outros. A abordagem, no entanto, diferencia-se de outros paradigmas de EPI, pois normalmente sua atenção recai na interação entre preferências de atores domésticos e instituições - tais como regime político, sistema partidário e eleitoral, veto players, autonomia do banco central -; mais especificamente, na forma como as regras agregam e transformam as preferências durante o processo político. Ou seja, deixa as variáveis políticas mais explícitas, permitindo maior interlocução entre as perspectivas econômicas e a ciência política Lake (2002). O fato de se dar atenção ao nível doméstico reflete o objetivo de se conferir mais rigor metodológico aos microfundamentos de macroteorias, pois o maior rigor científico significa desenvolver argumentos teóricos mais coerentes e calcados em resultados empíricos robustos. Em suma, os trabalhos em OEP se mostram com forte base empírica; dando enfase à análise dedutiva; e integrados a um amplo corpo teórico. Por essa razão, Lake argumenta, em tom irônico, que "This not only links OEP to broader research programs and facilitates cross-fertilization, but prevents analysts from reinventing the wheel each time they sit down at their computers"(Lake, 2008, 772).

Apenas para ilustrar a relação entre a perspetiva da OEP e outros paradigmas de EPI, tomase como exemplo o tema da abertura comercial. A literatura de OEP não se contraporia a abordagens fundamentadas em variáveis sistêmicas ou estruturais, como, por exemplo, a teoria da estabilidade hegemônica, derivada da escola realista e mobilizada por Krasner (1976) tanto no nível de análise como no método de validação das hipóteses. Nesta, argumenta-se que o fim da Guerra Fria, marcada pela queda do Muro de Berlim e a consequente emergência dos EUA como única potência mundial, conferindo um caráter unipolar à arquitetura de poder global, seriam fatores levantados com frequência para explicar a liberalização comercial em países em desenvolvimento. O mesmo fato, da perspectiva de Gilpin (1983), poderia justificar 
a emergência, difusão e aplicação de ideologias liberais, e.g., Consenso de Washington. Por fim, argumento igualmente plausível seria o surgimento de instituições internacionais como elemento explicativo para a onda liberalizante, pois elas poderiam servir para dirimir disputas entre os Estados e melhor coordenar seus interesses (Keohane, 1984).

Para o mesmo problema, são diversas as explicações apresentadas pela literatura de OEP dando atenção aos regimes, mas com uma perspectiva analítica distinta. Eichengreen and Leblang (2008) Frye and Mansfield (2004), Tavares (2008), Mansfield and Rosendorff (2000), Mansfield, Milner and Rosendorff (2002), e Wintrobe (2000), por exemplo, concedem atenção à relação entre regimes político e os níveis de proteção comercial de um Estado. Nesse sentido, a possível explicação para a abertura comercial no período pós-Guerra Fria seria a emergência de regimes democráticos. Mas a literatura vai além, buscando formas de se mensurar e testar os mecanismos. Mansfield and Rosendorff (2000), nesse sentido, afirmam que a cooperação em política comercial pode ser explicada pela variável regime político, e, à medida que os Estados se tornam mais democráticos, aumentam as possibilidades de concluírem acordos de livre-comércio. $\mathrm{O}$ argumento se baseia no fato de os líderes democráticos, diferentemente dos autoritários, estarem submetidos ao controle eleitoral, e os acordos supririam uma lacuna informacional. No nível doméstico, teriam a função de informar ao eleitor o compromisso do governo com o livre-comércio.

Pela diversidade de paradigmas em EPI, e pela variação de explicações possíveis dentro do paradigma OEP e, especialmente, por ser trabalho desenvolvido na área de relações internacionais, na qual abordagens sistêmicas quase sempre prevalecem, entendeu-se ser necessário especificar a qual perspectiva analítica este trabalho se alinha. O restante do capítulo está organizando da seguinte forma: na primeira parte, são apresentados estudos que investigam a relação entre sistemas eleitorais e resultados econômicos; em seguida, são analisados os trabalhos que tratam da relação entre a regras eleitorais e protecionismo; na terceira seção, segue-se 
a mesma linha, mas com foco nos trabalhos comparados. Por fim, faz-se uma discussão sobre as limitações e lacunas na literatura, apontando que direção deve ser tomada para avançar o conhecimento na área.

\subsection{Por que razão o Sistema Eleitoral?}

\subsubsection{Sistema Eleitoral e Resultados Econômicos}

De uma maneira geral, a ciência política moderna informa que as regras eleitorais são fatores centrais na geração de incentivos para aqueles que buscam se eleger; ou seja, uma das características mais essenciais do sistema político. A literatura associa o funcionamento e dinâmica dessas instituições com uma série de fenômenos, como grau de participação política (Blais and Dobrzynska, 1998; Blais and Carty, 1990); inclusão de minorias (Matland and Studlar, 1996); violência e instabilidade social (Cohen, 1997); proteção aos direitos humanos (Cingranelli and Filippov, 2010); corrupção (Kunicová and Rose-Ackerman, 2005; Persson, Tabellini and Trebbi, 2003); entre outros. No que diz respeito aos impactos econômicos dos sistemas de representação, a matéria não poderia ser diferente. De acordo com Carey and Hix (2013), trata-se de uma das áreas de pesquisa mais dinâmicas e que apresentam maior crescimento na ciência política.

A maior parte dos argumentos sobre a forma como os sistemas eleitorais afetarão os resultados econômicos depende da diferenciação entre interesses amplos ou nacionais e interesses locais ou paroquiais. Assim, a adoção de um determinando arranjo institucional relacionado com a representação política irá determinar que um dos interesses prevaleça sobre o outro. As variações das combinações entre entre as regras são inúmeras; por esse motivo, foca-se, aqui, nas três dimensões mais abordadas para caracterizar as regras eleitorais: a fórmula; a magnitude distrital; e o tipo de voto - pessoal ou partidário. 
O sistema ou a fórmula eleitoral diz respeito à maneira pela qual os votos são transformados em assentos no Legislativo, sendo classificado, basicamente, em dois grandes grupos: o majoritário e o proporcional. No sistema ou fórmula majoritária, apenas aquele que obtém a maior parte dos votos é eleito - no caso da regra da maioria simples; no proporcional, as cadeiras são divididas de forma equânime entre aqueles que obtiveram votação suficiente para o assento. O caso norte-americano, nas eleições para a House of Representatives, é um exemplo típico do primeiro, uma vez que o território nacional é dividido em 435 distritos e aquele candidato que obtiver a maioria simples será o representante eleito para o distrito específico. Em outro oposto, pode ser observado o caso de Israel, onde o território nacional é considerado um só distrito, no qual os 120 representantes são escolhidos por meio da proporção de votos obtidos.

A magnitude distrital representa o número de legisladores eleitos por cada distrito. Em um extremo, o distrito pode possuir magnitude igual a 1; em outro, um único distrito poderia eleger todos os legisladores. Nos EUA, citados no parágrafo anterior, ela é igual a 1; e no do Brasil irá variar de acordo com os distritos, alcançando uma magnitude média de 19. O distrito eleitoral formado pelo estado de São Paulo, por exemplo, elege 70 candidatos para a Câmara dos Deputados, logo, sua magnitude é de 70; já no Espírito Santo, outro distrito, é de 12. Nos países que adotam o sistema majoritário, os distritos são criados para fim eleitoral; nos que utilizam o proporcional, os distritos geralmente seguem o padrão das unidades subnacionais, com estados, províncias, regiões, como pode ser observado. A literatura indica também que existe uma associação entre a magnitude distrital e as fórmulas eleitorais. No primeiro, geralmente são utilizados distritos de magnitude igual a 1; no segundo, maiores do que 1 . No entanto, pode haver grande variação entre os próprios países que adotam a fórmula proporcional. A terceira dimensão, o tipo de voto, diz respeito às opções do eleitor entre votar em um candidato ou em uma lista partidária. Na fórmula majoritária, a regra é o voto no candidato, enquanto, na propor- 
cional, são duas as opções: lista fechada, indicando maior grau de influência dos partidos, pois a lista é previamente ordenada por ele; e lista aberta, atribuindo maior peso ao voto individual, pois é esta que determinará o ordenamento.

Carey and Shugart (1995) fazem interessante diferenciação entre a reputação pessoal e a reputação partidária, que auxilia a compreensão conceitual. A busca por reputação pessoal diz respeito aos incentivos que a melhora do prospecto eleitoral, em razão de o político ser conhecido e atrair a simpatia dos eleitores, gera sobre suas ações. Este fenômeno, por sua vez, estaria associado ao paroquialismo dos Legislativos, que tenderiam a focar nos vínculos locais e regionais, bem como a estreitá-los, por meio de busca de verbas para assistência de comunidades. No que diz respeito à reputação partidária, ela seria o grau de informação que o partido político repassa ao eleitor para formar sua opinião; quanto maior a influência do partido sobre os eleitores, maior a reputação partidária.

Se comparada com décadas de estudos sobre os efeitos dos sistemas eleitorais sistemas partidários, disciplina partidária, relação entre cadeiras e votos, estabilidades de coalizões governamentais, entre outros tópicos, pode-se afirmar que a agenda de pesquisa que trata da relação entre as regras eleitorais e resultados econômicos ainda se encontra em um estágio inicial. Apesar disso, já existem achados que vão se consolidando na área, tomando como ponto de partida principalmente as diferenças decorrentes das três dimensões apresentadas.

A literatura informa, por exemplo, que a fórmula proporcional tende a estar mais associada com gastos governamentais que beneficiam o provimento de bens públicos e com políticas redistributivas menos focadas. A causa para tanto repousaria no fato de que, se o bem público é muito desejado, o seu não-provimento reduz o apoio de eleitores não-centrais - non-pivotals; no sistema majoritário, os candidatos desprezariam esse custo (Bawn and Rosenbluth, 2006; Fabrizio and Mody, 2006; Funk and Gathmann, 2010; Gagliarducci, Nannicini and Naticchionia, 2011; Persson and Tabellini, 1999). No que diz re- 
speito à imposição de tributos, em razão da existência de um maior número de partidos e pelo fato de as coalizões serem definidas após as eleições, países com sistemas proporcional tenderiam a apresentar uma carga tributária mais elevada (Milesi-Ferretti, Perotti and Rostagno, 2002; Persson, 2002).

A relação entre magnitude distrital e alocação de recursos e gastos governamentais também é bastante explorada. Distritos maiores tendem a diluir a competição eleitoral, induzindo partidos a procurarem o apoio de grandes coalizões; distritos menores, ao contrário, direcionam a competição eleitoral para bases menores, geograficamente determinadas, que seriam o foco das campanhas e compromissos políticos. Se a implementação de políticas públicas mais amplas demanda base de apoio mais diversificada, e programas focais, o apoio de setores específicos, é possível concluir, intuitivamente, que países que dispõem de distritos maiores mostrariam maior tendência para a busca de políticas que atendam um maior número de cidadãos. Em suma, como informa Persson and Tabellini (2005), prevaleceria um trade-off entre representação e accountability. Em eleições majoritárias, os resultados são mais sensíveis às alterações marginais na distribuição de votos. Dessa forma, grupos marginais de eleitores poderão ser privilegiados ou sobre-representados nas câmaras, ocorrendo o contrário nas proporcionais.

O que pode ser concluído nesta breve passagem, além do fato óbvio de que as regras eleitorais podem produzir impactos significativos em resultados econômicos, é que as regras que determinam os sistemas de representação de uma nação também têm algum impacto na formatação das preferências comerciais de políticos eleitos. Tão interessante quanto a constatação da importância das regras, no entanto, é o destaque para os possíveis mecanismos pelos quais estas podem atuar sobre os resultados econômicos, que podem ser repensados para os fins de políticas protecionistas. Dessa forma, na análise que será feita na próxima subseção, dar-se-á atenção especial a esse aspecto. 


\subsubsection{Sistema Eleitoral e Comércio}

Uma vez compreendida a lógica da interação entre representação política e resultados econômicos, a da relação entre os sistemas eleitorais e os níveis de proteção comercial fica mais clara. Sabendo-se que toda política comercial é dotada de consequências distributivas, o que faz que alguns eleitores fiquem melhor do que outros, é possível pensar que uma variação significativa nos incentivos que afetam a competição eleitoral em Estados democráticos pode afetar a forma como os políticos que disputam cargos eletivos se comportam diante desse fenômeno. Como bem explica McGillivray (2004), a redistribuição é a essência da política, e políticos eleitoralmente motivados detêm incentivos para redistribuir recursos entre seus eleitores, privilegiando uns em detrimento de outros.

Rogowski (1987), ao comentar o assunto da perspectiva da magnitude distrital, simplifica a questão no seguinte exemplo: quando fabricantes de automóveis ou produtores agrícolas são o grupo dominante em 20 distritos pequenos e uma minoria com voz em outros 15 , certamente serão influentes no Legislativo nacional. No entanto, se representam não mais do que $1 \%$ ou $2 \%$ de um grande distrito, os representantes eleitos não serão tão dependentes de seus interesses (1987, 208). Isso ocorreria porque a melhor estratégia eleitoral para políticos e partidos em um ambiente com distritos maiores e sistema proporcional é recorrer a amplos segmentos da população com o intuito de maximizar seus votos, explica. Uma observação que deve ser ressaltada, pois primordial para a literatura, é a perspectiva de que políticos e partidos são office-seeking, ou seja, atores que buscam maximizar as chances de reeleição e, para esse fim, trabalham para prover benefícios àqueles eleitores mais determinantes. As regras eleitorais, portanto, são fatores institucionais centrais para identificação do eleitor, pois, dentre outros critérios, definem a magnitude distrital e a fórmula por meio da qual o representante será escolhido.

Nas últimas décadas, uma vasta literatura sobre determinantes políticos do comércio, especialmente voltada para o caso dos EUA, vem se apoiando nos argumentos acima apresen- 
tados para explicar o comportamento do Executivo e do Legislativo sobre a matéria, variando desde a adoção de tarifas até a assinatura de acordos comerciais. O trabalho elaborado por Schattschneider (1935) na década de 1930, em que analisa a Lei Smoot-Hawley, pode ser observado dessa forma. Ao traçar a tramitação da legislação no Congresso, o autor detecta a interferência de pressões de grupos de interesses e a responsividade de congressistas a eles, o que considera uma vitória do protecionismo, atribuído, em grande parte, ao excesso de demandas e interesses setoriais e à debilidade das instituições políticas. Dessa forma, enfatiza, acima de tudo, não o poder irrestrito dos grupos, mas a importância do processo político como causa e origem da influência desproporcional dos setores protecionistas. O desequilíbrio que beneficia esses interesses é consequência, portanto, não do poder que detêm, mas da debilidade das instituições que sustentam o processo político, o qual promove e perpetua o sistema de proteção indiscriminada. Conforme argumenta, a delegação de poderes ao Executivo poderia resultar em uma maior harmonização dos interesses em prol do livre-comércio, uma vez que sua base eleitoral (constituency) é mais ampla (1935, 268).

Pode-se argumentar, com segurança, que Schattschneider foi o precursor de uma série de estudos que vêm difundindo uma das teses mais tradicionais na área de EPI sobre a relação entre sistemas de representação e comércio nos EUA. Esta tese informa que, quanto maior a base eleitoral do policy-maker, maiores as chances de ele apoiar o livre-comércio (Baldwin, 1989; Destler, 2005; Gilligan, 1997; Lohmann and O’Halloran, 1994; Rogowski, 1987; Weingast, Goldstein and Bailey, 1997). O argumento decorre da visão de que o comércio é uma política distributiva ou vinculada a questões clientelistas. Dessa forma, cada distrito buscará aumentar as barreiras para os produtos que ali são produzidos; logo, em distritos maiores, a diversidade de interesses é maior, dificultando a ação de setores particulares, e, naturalmente, insulando o representante diante de interesses paroquiais.

Uma das teorias que derivam dessa explicação é a do presidente liberal, informando que 
a delegação de poderes para negociações comerciais para o presidente reduziria a incidência de políticas protecionistas, uma vez que a sua base eleitoral é nacional (Destler, 2005; Lohmann and O'Halloran, 1994; Schattschneider, 1935). Esse simples fato já indicaria que o chefe do Executivo deverá estar mais preocupado com o bem estar geral do que com interesses particularistas de determinados setores ou grupos de interesses. Lohmann and O'Halloran (1994) constroem sobre essa ideia seu argumento sobre governo dividido e a relação entre Executivo e Legislativo. Segundo os autores, os membros do Congresso e o chefe do Executivo compartilham constituencies diferentes, e, por isso, possuem objetivos distintos em política comercial. Cada legislador busca o benefício de seus próprios distritos, enquanto o presidente busca atender aos custos da soma dos distritos (1994, 599).

Um argumento também derivado da tese do tamanho da base parlamentar é o de que sistemas de representação proporcional, se comparados aos majoritários, seriam mais propícios ao livre-comércio (Mansfield and Busch, 1995; Rogowski, 1987). De acordo com Rogowski (1987), geralmente funcionando em distritos maiores, com vários membros, ao contrário dos majoritários, e permitindo, dessa forma, que os legisladores eleitos fiquem insulados em relação às demandas dos grupos de interesses. Para o autor, cujo argumento se assenta na relação da dinâmica comercial com o sistema político, o insulamento diante de pressões regionais e setoriais em regimes democráticos é mais facilmente alcançado em distritos maiores; a autonomia em relação aos mesmos interesses é alcançada, de forma mais eficiente, em sistemas com partidos fortes; e a estabilidade, em sistemas proporcionais (1987, 208). Um terceiro desdobramento dessa tese também pode ser observado em estudos que buscam associar características dos sistemas partidários às escolhas comerciais. Comumente, parte-se do pressuposto de que sistemas eleitorais seriam capazes de gerar partidos fortes ou fracos; partidos fortes, com lideranças centralizadas, seriam geralmente característicos do sistema proporcional e seriam mais aptos a insular os representantes dos interesses setoriais (Hankla, 2006; McGillivray, 1997; 
Nielson, 2003). Em estudo nessa linha, Hankla (2006) informa que a centralização das decisões partidárias e sua conexão com o eleitorado, mensurado por meio da base eleitoral, caracterizaram os partidos fortes. Outro aspecto tratado por essa literatura diz respeito à fragmentação partidária, pois o fenômeno poderia ser visto como um fator propício à entrada de interesses protecionistas no sistema político (Haggard and Kaufman, 1995; Nielson, 2003).

Apesar de trabalhos recentes apresentarem críticas diretas a algumas das teorias acimas expostas, especialmente no que diz respeito ao poder explicativo do tamanho da base eleitoral e sua relação com incentivos a posturas protecionistas (Ehrlich, 2009; Karol, 2007), acredita-se que, ainda, suas validações merecem mais testes empíricos para serem refutadas. Nos estudos de Karol e Ehrlich, que tratam avaliam as diferenças na votação em matérias de comércio entre os membros da Câmara e do Senado dos EUA, os indícios dão conta de que, para o caso específico, a base eleitoral não seria um fator determinante. No entanto, há necessidade de se avançar, especialmente, na área de política comparada.

\subsubsection{Testando Hipóteses em Estudos Comparados}

Na subseção anterior, apontou-se viés protecionista para arranjos institucionais majoritários, seja caracterizado pela fórmula, pelo tamanho do distrito, ou pelas características dos sistemas partidários. A maior parte dos achados derivam de trabalhos sobre política norte-americana, mas as hipóteses daí originadas foram rapidamente incorporadas à literatura comparada. A questão que emerge, portanto, é saber se esses foram empiricamente validados. A estrutura dos trabalhos abaixo apresentados segue lógica bastante similar. No lado esquerdo da equação, encontram-se medidas de proteção comercial; no lado direito, as variáveis de interesse são as instituições, de uma maneira geral, as regras eleitorais. Dessa forma, pretendem estimar o impacto do formato eleitoral sobre os níveis de proteção, buscando sempre responder as seguintes questões: primeiro, as regras eleitorais importam? Segundo, qual arranjo institucional levaria 
a resultados mais satisfatórios do ponto de vista econômico - baixos níveis de proteção? Os desenhos de pesquisa também são similares: todos são estudos observacionais, de coorte cross-section - ou em formato painel.

Num primeiro grupo de estudos, é possível vislumbrar certa convergência com os achados que indicam o viés protecionista em sistemas majoritários. Em trabalho de referência, Rogowski (1987) argumenta que países mais dependentes do comércio internacional optarão por instituições que promovem insulamento em relação a grupos de interesses, autonomia de partidos e estabilidade política. Nesse caso, informa que o insulamento em relação às pressões regionais e setoriais em uma democracia é mais facilmente atingido em sistemas com distritos eleitorais maiores; autonomia em relação ao setor privado, por meio de partidos fortes, característicos de sistemas proporcionais; e a estabilidade seria mais facilmente alcançada por meio da combinação de sistema proporcional e partidos fortes, em um sistema parlamentarista.

Os fatores que explicariam a conexão entre as características distritais e partidárias e os fenômenos do insulamento e da autonomia, assevera o autor, seriam quase triviais. Ao avaliar empiricamente a relação entre a dependência ao comércio, considerando o volume do fluxo comercial sobre o Produto Interno Bruto (PIB), e as instituições, o autor encontra evidências que confirmam sua hipótese: as características distritais, mensuradas por meio do número de distritos na câmara baixa, e a força partidária, por meio de índice de centralização partidária, encontram-se positivamente correlacionadas com comércio.

Nielson (2003), por sua vez, traz pesquisa mais ampla sobre a relação entre política protecionista e instituições domésticas. Suas hipóteses principais estão parcialmente relacionadas ao sistema eleitoral no sentido mais amplo - a divisão entre majoritário e proporcional -, mas a pesquisa traz resultados relevantes sobre a relação entre características dos distritos e os incentivos ao protecionismo. $\mathrm{O}$ autor enfatiza duas explicações centrais calcadas na delegação de poderes: incentivos eleitorais a favor do partido e delegação aos presidentes. Sobre o primeiro, 
aborda a questão da autonomia de políticos em relação ao partido - em especial, com relação à liderança partidária. Em uma situação na qual o político detém pouca autonomia, ou seja, quando os incentivos ao voto pessoal são baixos, existiria maior propensão a menos políticas protecionistas. Situação oposta seria aquela centrada no candidato.

A explicação fundamental para o seu modelo, no entanto, recai sobre o grau de delegação ao Executivo em regimes presidencialistas. Para Nielsen, em democracias presidencialistas, quanto mais poderes delegados ao chefe do Executivo, maior a probabilidade de ele rechaçar interesses setoriais. Duas explicações trazidas pelo autor e consideradas alternativas são o tamanho do distrito eleitoral - maior distrito, menor força de grupos de interesses - e o grau de fragmentação partidária, que guardaria uma correlação positiva com a força de interesses protecionistas. Os resultados encontrados por Nielsen confirmam as hipóteses teóricas apresentadas inicialmente, apontando influência significativa entre instituições que favorecem partidos e delegação ao Executivo com as variáveis a serem explicadas. Ao mesmo tempo, há indícios, mais fracos, de que o fator distrital e o número de partidos possam ter relação com o fenômeno.

Buscando discutir a explicação do fenômeno do protecionismo por meio da perspectiva dos partidos, Hankla (2006) afirma que, tudo mais constante, democracias que dispõem de partidos políticos fortes terão menor nível de protecionismo, entendendo por partidos fortes aqueles centralizados e com vínculos com grandes grupos eleitorais. Dessa forma, seria resultado de sistema político no qual haja baixo incentivo para o voto pessoal - a mesma medida usada por Nielson (2003), com base em Carey and Shugart (1995); grandes distritos, com baixa volatilidade eleitoral.

Por fim, Rickard afirma que as regras eleitorais podem ter impacto sobre o compliance em acordos internacionais (2010) e no nível de subsídios (2012) - barreiras não-tarifárias. No primeiro, a autora informa que, levando em consideração os aspectos distributivos desses tipos de tratados, países com sistema majoritário estariam mais propensos a violá-los. No segundo 
trabalho, e calcada em achados recentes da literatura, encontra evidências de que países que adotam o sistema majoritário fariam maior uso de subsídios para proteger a indústria nacional.

Em um segundo grupo, no entanto, os resultados são contrários às expectativas apontadas no início do texto. Evans (2009) argumenta que uma legislatura eleita por meio do sistema proporcional apresenta maior probabilidade de favorecer baixas tarifas, pois levaria em consideração os interesses de toda a nação; em oposição, estaria o sistema majoritário, por meio do qual aqueles eleitos representariam setores menores do eleitorado e estariam fadados a buscar os interesses desses, resultando em uma política com viés protecionista. Segundo a autora, portanto, políticos tendem a maximizar o bem-estar de seus distritos em detrimento do restante do país em um sistema majoritário. Os resultados encontrados, de acordo com Evans, confirmariam o viés protecionista do sistema majoritário. Ao mesmo tempo, em trabalhos mais recentes, informa que os resultados do impacto do sistema eleitoral vão depender do tipo de bem em análise, refutando a ideia de um viés protecionista na fórmula majoritária (Ardelean and Evans, 2013; Evans and Obradovich, 2011)

Em outro estudo, Mansfield and Busch (1995) informam que a explicação para a variação da adoção de medidas protecionistas por parte dos Estados depende da interação entre fatores societais - de origem econômica, como desemprego e política cambial - e estatais - por exemplo, o tamanho do Estado e suas instituições domésticas, como regras eleitorais. Assim, a hipótese que o estudo busca avaliar empiricamente é a de que a incidência do protecionismo seria menor quando um país apresentar instituições que garantam autonomia e insulamento diante de grupos de interesses aos seus políticos e, ao mesmo tempo, esteja diante de baixo desemprego e moeda apreciada. A conclusão a que chegam é a de que a interação de incentivos econômicos e tamanho do Estado com suas características institucionais importa para a adoção de barreiras protecionistas. De fato, quando tamanho do Estado, taxa de desemprego e taxa de câmbio atingem seus níveis máximos, combinado com o nível mais baixo do tamanho dos dis- 
tritos, a predição para incidência de barreiras não-tarifárias é 35\% mais elevada. Mas indicam impacto negativo da fórmula majoritária sobre as barreiras protecionistas.

Na tentativa de avaliar a relação entre instituições domésticas e comércio, Ehrlich (2007, 2011) argumenta que, ao contrário daqueles que buscam explicar as variáveis do nível de proteção comercial por meio de características institucionais singulares, como a dicotomia entre sistema majoritário e proporcional, uma abordagem mais ampla, que desse conta de um número maior de características institucionais, teria maior poder explicativo. Nesse sentido, apresenta a teoria dos pontos de acesso - access point -, que seriam policy-makers com poderes sobre uma determinada área de política, suscetíveis à ação de grupos de interesse por meio de lobby (2007, 576); assim, determinadas configurações institucionais gerariam mais ou menos pontos de acesso. Seguindo a lógica, quanto maior o número de pontos de acesso em um sistema político, mais baixo o custo de ação dos lobbies, e maiores as chances de implementação de políticas protecionistas. Maior número de distritos eleitorais, mais partidos, baixos níveis de disciplina partidária, bicameralismo e parlamentarismo seriam características institucionais positivamente correlacionadas com um maior nível de proteção.

Nos resultados apontados por Ehrlich, foram encontradas evidências de que as hipóteses apresentadas são verdadeiras para um grupo de países desenvolvidos no período do pós-guerra. Foram detectadas tarifas mais altas em países com maior número de partidos; com mais distritos eleitorais; com baixos níveis de disciplina partidária; e presidencialistas. Ao mesmo tempo, e era esse um dos principais objetivos do autor, controlando por número de partidos, distritos e disciplina partidária, o fato de o país adotar o sistema proporcional ou majoritário não teve efeito independente sobre o nível tarifário adotado. De certa forma, a ausência de resultados coincide com McGillivray (2004) e Mukherjee, Smith and Li (2009). 


\subsection{Discussão}

Como pôde ser observado, os estudos comparados, apesar de seguirem estruturas analíticas semelhantes, apresentam abordagens distintas, em diversas categorias: tipo de análise empreendida; seleção de países; variáveis que possam mensurar proteção comercial; e variáveis explicativas - políticas. Alguns padecem de restrições que derivam do tipo de análise de dados empreendida - cross-sectional -, e das próprias amostras, que impõem limites às conclusões. Mais relevante, no entanto, é perceber que esses estudos apresentam resultados contraditórios, podendo ser divididos entre aqueles que informam um viés protecionista para o sistema majoritário; os que informam um viés protecionista para o sistema proporcional; e aqueles que não encontram resultados sobre essa dinâmica.

Mesmo com os avanços empreendidos em pesquisas comparadas, foram detectadas algumas limitações e lacunas que, se supridas, podem representar considerável avanço em direção a resultados mais robustos. Dessa forma, considera-se que a maior contribuição que pode ser dada à literatura de EPI que aborda o tema seria identificar problemas e buscar suprir essas lacunas. Entende-se que três tópicos centrais devem ser abordados para o objetivo ser alcançado:

1) Proposição de teoria alternativa que possa dar conta, de maneira mais eficiente, do mecanismo de conexão entre sistemas eleitorais e proteção comercial;

2) Apresentação de medida mais refinada para se avaliar as diferenças entre os sistemas de representação entre os países;

3) Avaliação dos micro-fundamentos das possíveis teorias que buscam explicar o fenômeno em análise. 
O primeiro ponto decorre do fato de que, com pouquíssimas exceções, as diversas hipóteses levantadas para explicar a conexão entre representação política e protecionismo se originam da Constituency Size Assumption. Por mais que esta seja uma teoria parcimoniosa e intuitiva, alguns estudos de caso questionam o poder explicativo do mecanismo descrito por ela: o tamanho do distrito. Além do mais, o fato de não haver na literatura resultado acumulado coerente sobre sua força - muito pelo contrário - já deveria ser, por si só, um fator que levasse à busca de alternativas para se avaliar tal relação. Ehrlich $(2007,2011)$, por meio da teoria dos pontos de acesso, talvez tenha apresentado a tentativa mais próxima desse objetivo. Neste trabalho buscase, contudo, suprir tal necessidade ao se oferecer o modelo S-P de regulação para explicar a dinâmica entre a regra eleitoral e o nível de protecionismo.

O segundo ponto destacado é a necessidade de se ir além da dicotomia entre sistemas majoritário e proporcional, pois atrás desses dois grandes grupos há uma série de outros fatores que podem gerar incentivos distintos. Assim, poderia haver duas opções: uma seria desagregar as características institucionais, como o faz Hankla (2006), por exemplo, ao buscar avaliar a força dos partidos. Outra alternativa seria buscar variáveis que possam dar conta, da forma mais precisa possível, do mecanismo teórico sugerido. Park and Jensen (2007), por exemplo, dependem do nível de competição eleitoral para explicar a geração de incentivos protecionistas no setor agrícola, e fazem uso do Cox-Thresholds para servir de variável independente primária. Neste trabalho, para informar a relação elasticidade cadeiras-votos, o mecanismo apontado pela teoria utilizada nesta tese, utiliza-se o IDE, em vez de se recorrer à dicotomia sistema majoritário-sistema proporcional.

Por fim, o terceiro ponto trata da necessidade de testes mais robustos em relação ao mecanismo apontado pela teoria. A maior parte dos estudos citados compartilham a característica de terem desenho de pesquisa observacionais tradicionais, geralmente, com disposição de dados em painel, e assumem que, por meio da fórmula eleitoral, estão avaliando tanto tamanho do 
distrito como a preferência do legislador. Nos poucos que buscaram avaliar o mecanismo por trás do Constituency Size Assumption, por exemplo, os resultados foram negativos. No caso deste estudo, não foi possível avaliar o mecanismo no seu nível mais micro, que seriam as votações nominais em matéria de regulação comercial. No entanto, buscou-se, em dois estudos de caso, avaliar a Constituency Size Assumption, pois que, se refutada, além de se tornar mais uma evidência contrária a sua validade, informará haver espaço para novas explicações. 


\section{Capítulo 3}

\section{Analisando a Constituency Size Assumption Por Meio de Dois}

\section{Estudos de Caso: Brasil e Chile}

O objetivo primordial deste capítulo é verificar a influência do tamanho do distrito sobre o voto dos parlamentares. Essa preocupação decorre do fato de grande parte da literatura de EPI depender fortemente da Constituency Size Assumption quando se discute a preferência comercial de legisladores. Assim, busca-se avaliar o mecanismo causal apontado pela literatura tradicional, tendo como nível de observação o voto nominal de parlamentares em matérias que envolvem temas de política comercial por meio de estudos de caso sobre Brasil e Chile. Com esse desenho de pesquisa, espera-se avaliar de forma mais precisa o impacto das características dos distritos e das regras eleitorais a que estão submetidos os parlamentares nas respectivas posições sobre livre-comércio e testar a tradicional hipótese que decorre da Constituency Size Assumption.

Basicamente, o argumento explorado pela literatura informa que, em distritos grandes, quando políticos são eleitos para representar um grupo mais heterogêneo, e tendem a implementar programas - políticas - mais amplos, relacionados ao provimento de bens públicos, como o livre-comércio. Por outro lado, aqueles eleitos em distritos menores seriam mais responsivos a um menor número de eleitores e mais vulneráveis à influência de grupos de in- 
teresses; consequentemente, estariam mais propensos a implementar políticas para sua base eleitoral, como medidas protecionistas. Se essa perspectiva teórica estiver correta, controlandose por outros fatores, seria possível observar diferenças no comportamento do legislador de acordo com as características dos distritos definidos pelas regras eleitorais. Por exemplo, em países onde há variação significativa no tamanho dos distritos de deputados e de senadores - ou mesmo entre os próprios deputados ou entre os senadores - ou onde existem regras eleitorais distintas para eleger deputados e senadores, seriam esperadas posições divergentes em matéria de política comercial.

Apesar de as análise das regras eleitorais sob a forma do tamanho do distrito serem amplamente aplicadas na literatura, trabalhos que vão em busca dos micro-fundamentos da teoria não são tão frequentes em EPI. Exceção são os trabalhos de Karol (2007) e Ehrlich (2009), que se destacam por serem os primeiros a avaliar as implicações lógicas da teoria do tamanho do distrito no micro-nível. O desenho de pesquisa dos dois serve de modelo inicial para se avaliar o mesmo problema, mas para contextos distintos, neste capítulo. Ambos partem do pressuposto de que a grande aceitação da Constituency Assumption contrasta com o fato de haver pouquíssimos trabalhos que buscam averiguar, empiricamente, a validade do mecanismo recorrendo à análise das votações nominais.

Karol (2007) afirma que modelos clientelistas - pork-barel models - não representam, de forma acurada, a política comercial, pois, se a ação de lobby protecionista é forte em determinado distrito, o mesmo deve ser esperado da ação de grupos de interesse pró-comércio. Dessa forma, o fato de não se levar em consideração a influência de grupos pró-livre comércio, como firmas voltadas à exportação, indica fragilidade destas abordagens. Além do mais, reforça que, para o caso dos EUA, ainda não se empreendeu pesquisa para averiguar a validade da teoria, o que, na verdade, será feito pelo próprio Karol. Assim, o autor conduz extensa avaliação da Constituency Size Assumption, comparando as preferências comerciais de deputados e 
senadores, externadas por meio do voto nominal; e analisa o impacto do tamanho dos distritos sobre matérias legislativas específicas que tratam do comércio. Apesar de indicar que senadores estão mais propensos a votar a favor do livre-comércio, esse comportamento não é explicado por meio do tamanho do distrito. Ao final, o autor não encontra evidências que comprovam a teoria para o caso do legislador norte-americano. Ehrlich (2009) reforça as evidências apresentadas ao analisar 10 medidas legislativas votadas na House of Representatives e no Senado entre 1994 e 2004. O autor não obteve diferenças significativas na manifestação das preferências comerciais entre senadores e deputados. Além disso, os resultados são semelhantes no que diz respeito ao tamanho do distrito. Uma vez mais se refuta, portanto, a teoria para o caso dos EUA.

Assim como nos dois estudos citados que tratam do caso dos EUA e buscam comparar as votações de Representatives e Senators em legislações selecionadas, levando em consideração que os políticos eleitos para os respectivos cargos respondem a incentivos eleitorais distintos, também nos dois casos selecionados nesta pesquisa, senadores e deputados respondem a incentivos distintos. No Chile, ambos são eleitos de acordo com as mesmas regras eleitorais, o sistema binomial ${ }^{1}$. Ao mesmo tempo, existe variação populacional entre distritos de deputados e entre os distritos de senadores - os deputados são selecionados em regiões menores, e por isso mais homogêneas, denominadas distritos; enquanto os senadores são escolhidos em regiões geográficas maiores, denominadas circunscrições - circunscripciones -, e por isso mais heterogêneas. Cada circunscrição engloba de 2 a 8 distritos. Neste caso, pode-se comparar o comportamento de deputados entre si e de deputados e senadores.

No Brasil, é também de se esperar comportamento distinto entre senadores e deputados, mas por outras razões. Neste caso, os representantes compartilham o mesmo distrito eleitoral,

\footnotetext{
${ }^{1}$ Trata-se de um sistema majoritário com distritos de magnitude igual a 2 . Nele, cada partido apresenta dois candidatos e o eleitor escolhe apenas um. Os partidos somente obtêm as duas cadeiras do distrito caso o candidato mais votado receba o dobro de votos do segundo colocado.
} 
que são delimitados geograficamente pelos estados federativos; no entanto, são eleitos por sistemas eleitorais distintos: enquanto deputados são eleitos por meio do sistema proporcional, senadores são escolhidos por meio do voto majoritário. Além disso, existe uma diferença considerável entre distritos no que diz respeito ao número de eleitores entre senadores; ao número de eleitores e magnitude distrital entre deputados; e entre número de eleitores e magnitude distrital entre senadores e deputados.

Seguindo as principais hipóteses delineadas tanto por Karol (2007) como por Ehrlich (2009), se a teoria do tamanho do distrito for verdadeira para o caso do Brasil e para o caso do Chile, as seguintes afirmativas poderão ser verificadas:

Hipótese 1: Quanto maior o distrito eleitoral, maior será o apoio a medidas favoráveis ao livre-comércio por parte dos deputados.

Sobre a Hipótese 1, já que existe uma grande variação no tamanho do distrito nas eleições para deputados, utiliza-se como medida para distrito a magnitude distrital, número de eleitores, e a população distrital. Dessa forma, para o caso brasileiro, espera-se que representantes eleitos em grandes estados, como Bahia, Minas Gerais, Rio de Janeiro ou São Paulo, tenham maior chance de apoiar medidas favoráveis ao livre-comércio do que aqueles eleitos em estados pequenos, como Acre, Amapá, ou Espírito Santo. No caso do Chile, apesar de não haver variação na magnitude distrital, existe considerável diferença na população total dos distritos, bem como no número de eleitores. O distrito 29, por exemplo, localizado na região metropolitana de Santiago, tem população de mais de 700 mil habitantes, enquanto o distrito 59, em Aisén, tem pouco mais de 90 mil. Assim, também se esperam comportamentos distintos.

Hipótese 2: Senadores estão mais propensos a votar favoravelmente em matérias que versam sobre livre-comércio do que deputados. 
Já a Hipótese 2 foca nos diferentes incentivos entre deputados e senadores, uma vez que esses atores não são eleitos pelas mesmas regras eleitorais e trabalham em distritos de tamanhos pouco semelhantes. Levando-se em consideração essa variação, a literatura sugere que, em geral, senadores estariam mais propensos a apoiar medidas de livre-comércio do que deputados. Para o caso chileno, as regras eleitorais são as mesmas. O que ocorre, na verdade, é um aumento considerável no tamanho do distrito, gerando um ambiente mais heterogêneo em termos de preferências dos eleitores.

Para testar a Hipótese 1 e a Hipótese 2, propõe-se modelar as preferências dos legisladores, medidas pelo voto dado a matérias relacionadas à política comercial, utilizando o método da Estimativa por Máxima Verossimilhança (EMV). No caso, a variável dependente é uma dummy indicando voto contra ou a favor da matéria em questão. Para se obter o resultado mais acurado, segue-se o seguinte modelo geral - 3.1 -, que será adaptado para cada caso em razão de acesso aos dados. Estão representados na primeira linha da equação 3.1 o efeito do tamanho do distrito; o impacto de ser senador; e a filiação partidária dos respectivos representantes. Em seguida, variáveis de controle de caráter sócio-econômico e demográficas, comumente utilizadas pela literatura. A inclusão dessas variáveis tem a função de excluir a possibilidade de viés decorrente de variáveis omitidas. Por esse motivo, não serão discutidos os resultados das estimações deste grupo, uma vez que não essenciais para as conclusões substantivas.

$$
\begin{aligned}
\text { Voto } & =\beta_{0}+\beta_{1} \text { Distrito }+\beta_{2} \text { Senador }+\beta_{3} \text { Partido } \\
& +\beta_{4} \text { Economia }+\beta_{5} \text { Social }+\beta_{6} \text { Demográfico }+\varepsilon
\end{aligned}
$$

Por fim, é necessário ressaltar que, com exceção do trabalho de Feliú (2012), desconhecem- 
se pesquisas que tenham buscado investigar o impacto das características distritais sobre o nível de preferência de legisladores. Em sua investigação, Feliú analisa votações nominais nas Câmaras Baixas em seis países latino americanos - Argentina, Brasil, Chile, México, Paraguai e Peru -, encontrando indícios de que ideologia partidária e pertencimento à coalizão governista seriam fatores determinantes para votação relacionadas à política comercial. Nessa seção, no entanto, vai-se além desse objetivo, incluindo-se variáveis institucionais no modelo e votações oriundas do Senado. Além do mais, busca-se investigar hipótese distinta. Assim, é possível afirmar que os resultados são complementares e auxiliam na compreensão do comportamento do legislador no que diz respeito a matéria comercial.

A presente seção encontra-se divida em três partes. Na primeira, discute-se o caso brasileiro, quando são apresentados os dados, a especificação do modelo e os resultados. Em seguida, fazse o mesmo para o caso chileno. Ao final, discutem-se os resultados dos dois casos e suas possíveis implicações para a literatura de EPI.

\subsection{O Caso Brasileiro}

\subsubsection{Especificação do Modelo e Dados Utilizados}

Para avaliar a validade da Hipótese 1 e da Hipótese 2 para o caso brasileiro, propõe-se a estimação do modelo 4.2 apresentado abaixo. Na verdade, ele é derivado do modelo geral modelo 3.1 - e traz, além das variáveis de interesse, com destaque para Distrito, Senador e Partido, os controles também especificados, que são variáveis relativas a características econômicas, sociais e demográficas comumente utilizadas pela literatura. 


$$
\begin{aligned}
\text { Voto }= & \beta_{0}+\beta_{1} \text { Distrito }+\beta_{2} \text { Senador }+\beta_{3} \text { Partido }+ \\
& \beta_{4} \text { Agricultura }+\beta_{5} \text { Indústria }+\beta_{6} \text { Exportação }+ \\
& \beta_{7} \text { Gini }+\beta_{8} \text { Renda }+\beta_{9} \text { Urbana }+\beta_{10} \text { Informal }+ \\
& \beta_{11} \text { Região }+\varepsilon
\end{aligned}
$$

$\mathrm{Na}$ equação, a variável dependente, Voto, representa o voto nominal do parlamentar em matéria comercial e está codificada com valor 0 , quando significa voto contra o livre-comércio; e 1, quando favorável. Foram selecionadas 3.763 votações nominais de deputados e senadores sobre matérias relacionadas a comércio. Esses dados foram obtidos por meio da base de votações nominais do Centro Brasileiro Análise Planejamento (Cebrap) (CEBRAP, 2010) e incluem 13 projetos de lei de 5 legislaturas, entre os anos de 1995 e $2009^{2}$. Substantivamente, a amostra contém desde acordos do Brasil com países latino-americanos até medidas de redução unilateral de tarifas sobre bens. Vale ressaltar que, como pode ser observado na Tabela 3.1, nem todas as votações foram examinadas por ambas as casas; e todas as matérias tiveram, no mínimo, 10\% de desacordo.

Com relação às votações nominais sobre matérias comerciais, o caso brasileiro merece atenção especial. Apesar de a Constituição informar que todo tratado internacional deve ser ratificado pelo Poder Legislativo antes de sua internalização na esfera jurídica doméstica, não foi possível obter votações nominais sobre os principais acordos negociados pelo país nas duas últimas décadas, como o Mercado Comum do Sul (Mercosul), a OMC e outros acordos bilat-

2 49ª Legislatura (1991-1995); 50ª Legislatura (1995-1999); 51ª Legislatura (1999-2003); 52 $2^{\mathrm{a}}$ Legislatura (2003-2007); a 53 Legislatura (2007-2011). 
Tabela 3.1: Legislação Relacionada a Comércio - 1995-2009

\begin{tabular}{lrccc}
\hline Conteúdo da Lei e Instituição Legislativa & N.da Lei & Ano & $\begin{array}{c}\text { Voto } \\
\text { Favor }\end{array}$ & Contra \\
\hline $\begin{array}{l}\text { Implementação dos Acordos TRIPS-OMC } \\
\text { Câmara dos Deputados }\end{array}$ & PL 824/91 & 1996 & 254 & 190 \\
Senado & PLC 115/93 & 1996 & 39 & 22 \\
& & & & \\
$\begin{array}{l}\text { Desregulamentação de Investimento Estrangeiro } \\
\text { Câmara dos Deputados }\end{array}$ & PEC 06 & 1995 & 353 & 128 \\
Senado & PEC 32, PEC 33 & 1995 & 62 & 14 \\
& & & & \\
Acordo com Bolívia & & & & \\
Câmara dos Deputados & PDC 337 & 1996 & 215 & 72 \\
& & & & \\
Acordo com Indonésia & & & & \\
Câmara dos Deputados & PDC 658 & 1998 & 278 & 78 \\
Acordo com Paraguai & & & & \\
Câmara dos Deputados & MPV 391 & 2007 & 270 & 89 \\
Câmara dos Deputados & PL 2105 & 2007 & 297 & 98 \\
Corte Tarifário em Bens Específicos & & & & \\
Câmara dos Deputados & MPV 392 & 2007 & 328 & 112 \\
Senado & MPV 392 & 2007 & 40 & 16 \\
$\begin{array}{l}\text { Zonas de Processamento de Exportação } \\
\text { Câmara dos Deputados }\end{array}$ & & & & \\
Acordo com Venezuela & MPV 418 & 2008 & 357 & 63 \\
Câmara dos Deputados & & & & \\
Senado & PDS 403 & 2008 & 265 & 61 \\
& PDS 403 & 2009 & 35 & 27 \\
\hline
\end{tabular}

erais $^{3}$. Isso ocorreu - e ocorre - em razão de a maioria deles ter sido objeto de negociação direta entre o Executivo e o Legislativo antes mesmo de chegar no Plenário da Câmara dos Deputados ou do Senado, e, nesta situação, ao momento da votação, eram aprovados por consenso. Por essa razão, no processo de seleção dos projetos de lei, buscou-se não se limitar a amostra a matérias restritas à redução tarifária, mas também incluir legislação que buscasse abrir o mercado nacional à competição estrangeira. Por exemplo, uma das matérias inclusas ${ }^{3}$ Por exemplo: Legislação OMC (MCS 83 /2007; PCD 62/2007; DL 262; MCS 1095/99; PCD 391/2000; DL 295; MCS 223/1996; PCD 284/1996; DL 296/2007); Acordos bilaterais: (CAN MCS 628/2005; PCD 19/2007; DL170/2009); (México MCS120/2003; PCD 733;DL 290/2006); (Bolívia MCS 83 PCD 817/2003 DL 195/2004); (Israel MCS 813/2008 PCD 1665/2009 DL 936; (Chile MCS 661/200 PCD 951/2001 DL 606/2003) 
foi o projeto de lei que objetivava desregulamentar a entrada de investimento externo no país, pois se entendeu que, uma vez que o Brasil estivesse com o mercado doméstico aberto ao capital estrangeiro, esse fato iria promover maior competição em setores específicos, promovendo consequentemente busca por proteção. Pela mesma razão, foram incluídas legislações que implementavam acordos de livre-comércio estabelecidos por tratados anteriores, como foi o caso dos Acordos TRIPS.

Tabela 3.2: Estatística Descritiva I, Brasil

\begin{tabular}{lccccc}
\hline \hline Variável & $\mathrm{N}$ & Média & Desvio Padrão & Min & Max \\
\hline Número de Eleitores & 3,763 & $8,271,443.000$ & $7,866,497.000$ & $135,778.500$ & $29,874,946.000$ \\
Magnitude Distrital & 3,763 & 31.382 & 20.893 & 8 & 70 \\
Gini & 3,763 & 0.552 & 0.040 & 0.426 & 0.644 \\
Renda Per Capita & 3,763 & 604.753 & 224.628 & 223.550 & $1,468.050$ \\
Informal (\%) & 3,763 & 54.75 & 11.25 & 34.96 & 85.23 \\
População Urbana (\%) & 3,763 & 79.70 & 11.30 & 49.20 & 96.60 \\
Exportação (\%) & 3,763 & 15.60 & 12.70 & 0.02 & 72.20 \\
Agricultura (\%) & 3,763 & 8.31 & 5.9 & 0.30 & 27.90 \\
Indústria (\%) & 3,763 & 26.43 & 8.36 & 5.58 & 52.87 \\
\hline
\end{tabular}

Para mensurar o tamanho do distrito (Distrito), considerada a variável independente primária, foram utilizadas duas medidas: a magnitude do distrito (Distrito1), que significa o número de legisladores eleitos em cada localidade; e número de eleitores por distrito (Distrito2). No Brasil, o número de eleitores varia, de forma considerável, entre os distritos, e, historicamente, possui o mesmo desenho geográfico do desenho dos estados federativos tanto para senadores como para deputados. Por exemplo, o estado de Roraima possui 135.800 eleitores enquanto São Paulo possui 29.870.000. Nos 26 distritos eleitorais brasileiros, a média do número de eleitores é de 8.271.442 com desvio padrão de 7.866.497. Por mais que a magnitude do distrito também varie de forma considerável para o cargo de Deputado Federal, ele está limitado, por regra constitucional, ao mínimo de 8 e ao máximo de 70 por estado, o que faz que um candidato em São Paulo represente algo em torno de 460 mil eleitores e um candidato em Roraima, por volta de 17 mil. Para o cargo de senador, o cenário é sensivelmente distinto, já que a magnitude é fixa - 
Tabela 3.3: Estatística Descritiva II, Brasil

\begin{tabular}{llrrr} 
Variáveis & Níveis & $\mathbf{n}$ & $\%$ & $\sum \%$ \\
\hline Vote & Contra & 987 & 26.2 & 26.2 \\
& A Favor & 2776 & 73.8 & 100.0 \\
\hline \hline Legislador & Dodos & 3763 & 100.0 & \\
& Seputados & 3508 & 93.2 & 93.2 \\
& Todos & 3763 & 100.0 & \\
\hline \hline Partido Político & PFL/DEM & 565 & 15.0 & 15.0 \\
& PMDB & 694 & 18.4 & 33.5 \\
& SPR & 702 & 18.7 & 52.1 \\
& SPL & 593 & 15.8 & 67.9 \\
& PSDB & 516 & 13.7 & 81.6 \\
& PT & 510 & 13.6 & 95.1 \\
& PTB & 183 & 4.9 & 100.0 \\
\hline Todos & 3763 & 100.0 & \\
\hline \hline Região & CO & 330 & 8.8 & 8.8 \\
& NE & 1125 & 29.9 & 38.7 \\
& NO & 493 & 13.1 & 51.8 \\
& SE & 1264 & 33.6 & 85.4 \\
& SO & 551 & 14.6 & 100.0 \\
\hline Todos & 3763 & 100.0 & \\
\hline
\end{tabular}

3 senadores por distrito -, mas há variação no número de eleitores, fator que aumenta a desproporcionalidade entre aqueles representados pelos senadores eleitos. Assim, enquanto o número de eleitores é usado para mensurar o tamanho do distrito para ambos, deputados e senadores, a magnitude distrital será usada apenas como proxy do tamanho do distrito para deputados.

No modelo de regressão logística multivariada apresentado acima, outras variáveis para se controlar por fatores sócio-econômicos também foram incluídas ${ }^{4}$, como, por exemplo, o Coeficiente de Gini por distrito (Gini); renda per capita (Renda); porcentagem da atividade agrícola na economia distrital (Agricultura); porcentagem de exportação na economia distrital (Exportação $)^{5}$; nível de informalidade na economia (Informal); e a porcentagem da população urbana (Urbana). Além do mais, buscou-se controlar por Região de origem do legislador - Norte (NO), Nordeste (NE), Centro-oeste (CO), Sudeste (SE) e Sul ( SL) - e por filiação partidária (Par-

${ }^{4}$ Os dados relativos às variáveis sócio-econômicas são do Instituto de Pesquisa Econômica Aplicada (Ipea) e estão disponíveis no website http://www.ipeadata.gov.br.

5 Dados do Ministério do Desenvolvimento, Indústria, Comércio Exterior (MDIC) disponíveis no website AliceWeb: http://aliceweb.desenvolvimento.gov.br/ 
tido). Além dos cinco principais partidos do país - Democratas (DEM), Partido do Movimento Democrático Brasileiro (PMDB), Partido da Social Democracia Brasileira (PSDB), Partido dos Trabalhadores (PT), e Partido Trabalhista Brasileiro (PTB), os demais partidos foram classificados em dois grupos: Partidos Pequenos de Esquerda (PPE) e Partidos Pequenos de Direita (PPD). As Tabelas 3.2 e 3.3 apresentam as estatísticas descritivas de cada variável mencionada.

\subsubsection{Resultados}

Os efeitos do tamanho do distrito sobre as preferências do legislador foram estimados por meio da análise de todas as votações nominais de procedência na Câmara dos Deputados. Os resultados estão expostos e resumidos na Tabela 3.4. As duas medidas propostas para tamanho do distrito - magnitude distrital e número de eleitores - são estatisticamente significantes e indicam o mesmo padrão. No entanto, apresentam resultados que são justamente contrários aos preditos pela teoria. Levando-se em consideração a magnitude distrital (Modelo 1), para cada mudança unitária na variável Distritol, o log de chance de apoiar medidas favoráveis ao livre-comércio cai 0.30. Em termos de razão de chance, é possível afirmar que, a cada deputado adicional por distrito, esta diminui por um fator de 0.72 . Os resultados do Modelo 2, em que a variável independente primária é a o número de eleitores, são semelhantes. Para cada acréscimo unitário em Distrito2, o log de chance para se votar a favor de livre-comércio se reduz em 0.23, o que significa dizer que, em termos de razão de chance, para cada 1000 eleitores adicionais por distrito, a chance de apoio se reduz em 0.76 .

Além do mais, entre as variáveis de controle, a indicação de filiação partidária apresentou resultados significativos e consistentes, confirmando o alto grau de disciplina partidária na política brasileira. Tendo o PMDB como categoria de referência em razão de seu posicionamento centrista no espectro ideológico da política brasileira (Power and Zucco, 2012), os achados indicam que partidos mais à direta estão mais dispostos a apoiar o livre-comércio (PTB e 
Tabela 3.4: Resultado Regressão, Brasil I

\section{Voto Livre-comércio}

Model 1

Model 2

\begin{tabular}{|c|c|c|}
\hline & & \\
\hline $\log$ (Distrito) & $\begin{array}{c}-0.300^{* * *} \\
(0.110)\end{array}$ & \\
\hline $\log ($ Distrito2) & & $\begin{array}{c}-0.234^{* * *} \\
(0.084)\end{array}$ \\
\hline PFL/DEM & $\begin{array}{c}-0.756^{* * *} \\
(0.148)\end{array}$ & $\begin{array}{c}-0.767^{* * *} \\
(0.148)\end{array}$ \\
\hline PPD & $\begin{array}{l}1.211^{* * *} \\
(0.198)\end{array}$ & $\begin{array}{l}1.205^{* * *} \\
(0.198)\end{array}$ \\
\hline PPE & $\begin{array}{c}-1.080^{* * *} \\
(0.144)\end{array}$ & $\begin{array}{c}-1.083^{* * *} \\
(0.144)\end{array}$ \\
\hline PSDB & $\begin{array}{c}-1.448^{* * *} \\
(0.144)\end{array}$ & $\begin{array}{c}-1.454^{* * *} \\
(0.144)\end{array}$ \\
\hline $\mathrm{PT}$ & $\begin{array}{c}-0.823^{* * *} \\
(0.148)\end{array}$ & $\begin{array}{c}-0.827^{* * *} \\
(0.148)\end{array}$ \\
\hline РTB & $\begin{array}{c}0.680^{* *} \\
(0.280)\end{array}$ & $\begin{array}{c}0.683^{* *} \\
(0.280)\end{array}$ \\
\hline Agricultura & $\begin{array}{c}-0.00000^{* *} \\
(0.00000)\end{array}$ & $\begin{array}{c}-0.00000^{* *} \\
(0.00000)\end{array}$ \\
\hline Exportação & $\begin{array}{c}0.00000 \\
(0.00000)\end{array}$ & $\begin{array}{c}0.00000^{* *} \\
(0.00000)\end{array}$ \\
\hline Indústria & $\begin{array}{c}-0.0002^{* *} \\
(0.0001)\end{array}$ & $\begin{array}{r}-0.0001^{*} \\
(0.0001)\end{array}$ \\
\hline Gini & $\begin{array}{c}-3.954^{* *} \\
(1.828)\end{array}$ & $\begin{array}{c}-4.182^{* *} \\
(1.857)\end{array}$ \\
\hline $\log ($ Renda $)$ & $\begin{array}{c}-0.147 \\
(0.444)\end{array}$ & $\begin{array}{c}-0.054 \\
(0.452)\end{array}$ \\
\hline Informal & $\begin{array}{c}0.023^{*} \\
(0.014)\end{array}$ & $\begin{array}{c}0.020 \\
(0.013)\end{array}$ \\
\hline $\mathrm{NE}$ & $\begin{array}{c}0.112 \\
(0.338)\end{array}$ & $\begin{array}{c}0.175 \\
(0.346)\end{array}$ \\
\hline NO & $\begin{array}{c}-0.038 \\
(0.287)\end{array}$ & $\begin{array}{c}-0.172 \\
(0.284)\end{array}$ \\
\hline SE & $\begin{array}{c}0.374 \\
(0.272)\end{array}$ & $\begin{array}{c}0.291 \\
(0.253)\end{array}$ \\
\hline SO & $\begin{array}{c}0.044 \\
(0.255)\end{array}$ & $\begin{array}{c}-0.060 \\
(0.244)\end{array}$ \\
\hline Urbana & $\begin{array}{c}-0.799 \\
(1.262)\end{array}$ & $\begin{array}{c}-0.800 \\
(1.272)\end{array}$ \\
\hline Constante & $\begin{array}{c}5.572 \\
(3.616)\end{array}$ & $\begin{array}{c}7.783^{* *} \\
(3.552)\end{array}$ \\
\hline $\mathrm{N}$ & 3508 & 3508 \\
\hline Log Likelihood & -1759.580 & -1759.384 \\
\hline
\end{tabular}

${ }^{* * *} \mathrm{p}<.01 ;{ }^{* *} \mathrm{p}<.05 ;{ }^{*} \mathrm{p}<.1$ 
Tabela 3.5: Resultado Regressão, Brasil II

Voto Livre-comércio

\begin{tabular}{|c|c|}
\hline Senador & $\begin{array}{c}-0.435^{* * *} \\
(0.153)\end{array}$ \\
\hline PFL/DEM & $\begin{array}{c}-0.391^{* *} \\
(0.172)\end{array}$ \\
\hline PPD & $\begin{array}{l}1.329^{* * *} \\
(0.222)\end{array}$ \\
\hline PPE & $\begin{array}{c}-0.684^{* * *} \\
(0.176)\end{array}$ \\
\hline PSDB & $\begin{array}{c}-0.827^{* * *} \\
(0.174)\end{array}$ \\
\hline PT & $\begin{array}{c}-0.542^{* * *} \\
(0.182)\end{array}$ \\
\hline PTB & $\begin{array}{l}0.936^{* * *} \\
(0.307)\end{array}$ \\
\hline Agricultura & $\begin{array}{r}-0.00000^{*} \\
(0.00000)\end{array}$ \\
\hline Exportação & $\begin{array}{c}0.00000 \\
(0.00000)\end{array}$ \\
\hline Indústria & $\begin{array}{c}-0.0002^{* *} \\
(0.0001)\end{array}$ \\
\hline Gini & $\begin{array}{c}-4.588^{* *} \\
(2.055)\end{array}$ \\
\hline $\log ($ Renda $))$ & $\begin{array}{c}-1.146^{* *} \\
(0.540)\end{array}$ \\
\hline Informal & $\begin{array}{c}-0.011 \\
(0.016)\end{array}$ \\
\hline NE & $\begin{array}{c}-0.152 \\
(0.403)\end{array}$ \\
\hline cuerdo Estratégico NO & $\begin{array}{c}-0.134 \\
(0.333)\end{array}$ \\
\hline $\mathrm{SE}$ & $\begin{array}{c}0.048 \\
(0.305)\end{array}$ \\
\hline SO & $\begin{array}{c}-0.146 \\
(0.301)\end{array}$ \\
\hline Urbana & $\begin{array}{c}-0.947 \\
(1.454)\end{array}$ \\
\hline Constante & $\begin{array}{l}13.402^{* * *} \\
(4.492)\end{array}$ \\
\hline $\mathrm{N}$ & 1946 \\
\hline Log Likelihood & -1085.278 \\
\hline
\end{tabular}


PPD); enquanto partidos mais à esquerda, como o PT e os PPS, junto com o PSDB, concedem menos apoio.

Como já mencionado, deputados e senadores são eleitos de forma distinta no Brasil. Primeiro, os membros do Senado são eleitos em distritos maiores, se considerarmos o número de votos de que os senadores precisam para se eleger. Mais importante, no entanto, eles são eleitos por meio de regras diferentes, sistema majoritário, enquanto deputados são eleitos por meio do sistema proporcional. Dadas essas diferenças, especialmente no que concerne ao tamanho do distrito, espera-se um comportamento distinto. Para testar o impacto de ser um senador, foram selecionadas 4 votações que passaram pelas duas Casas Legislativas e estimadas por meio de modelo semelhante ao apresentado na seção anterior, com a adição de uma variável dummy para a condição de senador - Senador -, sendo codificada como 0 para deputados e 1 para senadores. Apesar de os coeficientes serem estatisticamente significantes, os resultados apresentados na Tabela 3.5 indicam que a direção do coeficiente vai contra as predições teóricas. $\mathrm{O}$ $\log$ de chance de votar favoravelmente ao livre-comércio é de 0.43 quando se é senador, o que significa que a razão de chance de apoiar essas medidas se reduz por um fator de 0.65 sob a mesma condição. Em relação à filiação partidária, os padrões não foram alterados com relação aos resultados da Tabela 3.5.

Os resultados resumidos nas Tabelas 3.4 e 3.5 indicam, portanto, que a abordagem teórica do tamanho do distrito, a princípio, não se aplica ao caso brasileiro. Primeiro, não foi possível encontrar evidências de que, quanto maior o distrito eleitoral, medido por meio de sua magnitude e pelo número de eleitores, maior seria o suporte dado por legisladores a medidas liberalizantes, conforme previsto na Hipótese 1. Segundo, não foi possível identificar se senadores são mais favoráveis ao livre-comércio do que deputados, como informado pela Hipótese 2. No entanto, mesmo diante dos resultados negativos, foi possível se verificar um padrão de comportamento nas votações que será discutido em detalhes na seção seguinte. Mesmo não sendo 
possível encontrar evidências que confirmem as predições da teoria do tamanho do distrito, acredita-se que os achados até o momento apresentados contribuem tanto para a literatura de política legislativa brasileira como para o campo de EPI, tópico que será discutido mais adiante. No que tange à primeira, é sabido que o Poder Legislativo brasileiro é uma das instituições mais estudas do mundo, mas, apesar de tal constatação, não há registro de estudos que tenham buscado aprofundar a análise das preferências comerciais dos legisladores brasileiros e seus possíveis determinantes.

O escasso número de trabalhos poderia ser explicado pelo fato de, tradicionalmente, o Executivo ter sido o percebido como o principal ator na arena da política externa econômica. Por exemplo, os principais tratados internacionais que versam sobre comércio negociados pelo Brasil, como o Mercosul, a OMC, entre outros, não resultaram em votações nominais no Congresso. A maior parte deles foi negociada diretamente entre o Executivo e lideranças partidárias antes mesmo de se chegar a plenário, e aprovada por consenso. Esse cenário ajudou a nutrir um debate, já superado, de que legisladores pouco se interessam pelos temas em questão. Além disso, um ponto já consolidado na literatura sobre estudos legislativos brasileiros e que tem como alicerce o trabalho de Figueiredo and Limongi (1999) indica que o sistema é altamente previsível em razão de deputados e senadores normalmente votarem de acordo com as recomendações das lideranças partidárias. Diante deste fato, o Executivo tem uma alta taxa de sucesso em razão do controle sobre a base, garantido por meio da disciplina - ou seja, fazer parte das coalizões, tanto governista como oposicionista, explicaria grande parte do comportamento legislativo.

Por tudo informado, a pesquisa foi conduzida de forma bastante cética no que diz respeito à possibilidade de se encontrar qualquer outro determinante, que não fosse filiação partidária, no posicionamento legislativo sobre livre-comércio. A alta taxa de disciplina partidária, informada pela literatura, está evidente nas Tabelas 3.4 e 3.5. No entanto, pode-se afirmar que, em se tratando de temas relacionados ao comércio exterior, o tamanho do distrito importa, um achado 
ainda não informado - ou mesmo estudado - pela literatura brasileira. E, apesar de os resultados encontrados irem de encontro à teoria do tamanho do distrito, diante dos padrões encontrados não se tem dúvidas de que se avança para um maior conhecimento de como o legislador age diante de matérias de natureza comercial, tema bastante específico e de grande relevância.

\subsection{O Caso Chileno}

\subsubsection{Especificação do Modelo e Dados}

Com o intuído de testar a Hipótese 1 e Hipótese 2 expostas na introdução do capítulo para o caso chileno, propõe-se a estimação do modelo 3.3 apresentado abaixo. É necessário recordar que, em razão da assimetria de acesso a dados distritais, não foi possível encontrar as mesmas informações para Brasil e Chile, de forma que o modelo 3.3, a ser estimado para o Chile, é uma especificação do modelo modelo teórico 3.1. Naturalmente, ele apresenta as variáveis de interesse - População Distrital, Senador e Partido -, juntamente com variáveis de controle relativas a características econômicas, sociais e demográficas.

$$
\begin{aligned}
\text { Voto }= & \beta_{0}+\beta_{1} \text { PopDistrital }+\beta_{2} \text { Senador }+\beta_{3} \text { Partido }+ \\
& \beta_{4} \text { Renda }++\beta_{5} \text { Desemprego }+\beta_{6} I D H+ \\
& \beta_{7} \text { Empregados Setor Agrário }+\beta_{10} \text { PopUrbana }+\varepsilon
\end{aligned}
$$

Tal como já informado, neste capítulo se objetiva estimar os determinantes políticos do voto em matéria de política comercial, de forma que a variável dependente, Voto, representa os votos nominais dos parlamentares chilenos sobre o assunto. Seu valor é 0, quando deputa- 
dos ou senadores votam contra o livre-comércio; e 1, caso os parlamentares votem favoravelmente. Foram selecionados 2.266 votos nominais provenientes da Câmara e do Senado. Em relação às informações sobre deputados, recorreu-se aos dados disponíveis no trabalho de Feliú (2012). Sobre senadores, recorreu-se à base original, organizada especificamente para este estudo, tendo como fonte o website do Senado do Chile ${ }^{6}$. No total, são 23 projetos - 11 da Câmara dos Deputados e 12 do Senado - entre os anos de 1996 e 2006, que cobrem três legislaturas ${ }^{7}$, resumidos na Tabela 3.6. Ainda sobre a seleção das votações, foram retiradas da análise estatística aqueles votos provenientes dos denominados senadores designados - ou institucionais - e dos senadores vitalícios, pois estes, por não serem democraticamente eleitos, não representam circunscrições. Sobre a composição do Legislativo chileno, vale ressaltar que, até 2006, o Senado era composto por 38 senadores eleitos e 9 designados por outras instituições. Além do mais, ex-presidentes assumiam o cargo de senador vitalício. Com isso, a amostra abrange a totalidade dos deputados - 120 por legislatura - e o grupo de senadores eleitos -38 por legislatura.

Na seleção das matérias sobre comércio, diferentemente do caso brasileiro, esse não foi um problema ao analisar o Chile; muito pelo contrário. Como o país adota uma política agressiva de implementação de Tratados de Livre-comércio (TLC), a adoção desse critério parece ser mais eficiente para se determinar que votar contra ou a favor de determinado TLC é um bom indicador da preferência do legislador sobre livre-comércio e sua tendência a atender demandas protecionistas. Assim, com exceção de votação que trata de redução unilateral de tarifas sobre importação, todas as matérias selecionadas são relativas a TLCs e foram submetidas ao escrutínio de ambas as Casas Legislativas. Dentre os acordos, encontram-se os mais sensíveis e que mais chamaram a atenção da opinião pública no período, como o TLC com o Mercosul ou com os EUA. Um problema, no entanto, é que nem todas as matérias expostas na Tabela

\footnotetext{
${ }^{6} \mathrm{http}: / / \mathrm{www}$. senado.cl/.

${ }^{7}$ XLIX Legislatura, 1994-1998; L Legislatura, 1998-2002; LI Legislatura, 2002-2006.
} 
Tabela 3.6: Votação Nominal sobre Comércio, Chile (1996-2006)

\begin{tabular}{|c|c|c|c|c|}
\hline Conteúdo da Lei e Instituição Legislativa & N.do Projeto & Ano & $\begin{array}{l}\text { Voto } \\
\text { Favor }\end{array}$ & Contra \\
\hline \multicolumn{5}{|l|}{ Tratado de Livre-comércio Mercosul } \\
\hline Câmara dos Deputados & $1891-10$ & 1996 & 73 & 26 \\
\hline Senado & $1891-10$ & 1996 & 28 & 4 \\
\hline \multicolumn{5}{|l|}{ Redução Unilateral de Tarifas } \\
\hline Câmara dos Deputados & 2218-05 (Votação 1) & 1998 & 52 & 35 \\
\hline Câmara dos Deputados & 2218-05 (Votação 2) & 1998 & 51 & 17 \\
\hline Senado & 2218-05 (Votação 1) & 1998 & 18 & 5 \\
\hline Senado & 2218-05 (Votação 2) & 1998 & 15 & 6 \\
\hline Senado & 2218-05 (Votação 3) & 1998 & 17 & 7 \\
\hline \multicolumn{5}{|l|}{ Tratado de Livre-comércio América Central } \\
\hline Câmara dos Deputados & $2467-10$ & 2001 & 81 & 1 \\
\hline Senado & $2467-10$ & 2001 & 17 & 4 \\
\hline \multicolumn{5}{|l|}{ Adequação Legislação OMC } \\
\hline Câmara dos Deputados & 2421-03 & 2002 & 95 & 0 \\
\hline Senado & $2421-03$ & 2003 & 26 & 10 \\
\hline \multicolumn{5}{|l|}{ Tratado de Livre-comércio EUA } \\
\hline Câmara dos Deputados & $3318-10$ & 2003 & 87 & 8 \\
\hline Senado & $3318-10$ & 2003 & 26 & 10 \\
\hline \multicolumn{5}{|l|}{ Tratado de Livre-comércio União Europeia } \\
\hline Câmara dos Deputados & $3147-10$ & 2002 & 107 & 3 \\
\hline Senado & $3147-10$ & 2003 & 32 & 2 \\
\hline \multicolumn{5}{|l|}{ Tratado de Livre-comércio Coreia } \\
\hline Câmara dos Deputados & $3279-10$ & 2003 & 95 & 0 \\
\hline Senado & $3279-10$ & 2004 & 33 & 0 \\
\hline \multicolumn{5}{|l|}{ Tratado de Livre-comércio AELC } \\
\hline Câmara dos Deputados & $3573-10$ & 2004 & 87 & 8 \\
\hline Senado & $3573-10$ & 2004 & 23 & 4 \\
\hline \multicolumn{5}{|l|}{ Tratado de Livre-comércio China } \\
\hline Câmara dos Deputados & $4170-10$ & 2006 & 96 & 1 \\
\hline Senado & $4170-10$ & 2006 & 30 & 0 \\
\hline \multicolumn{5}{|l|}{ Acordo Estratégico Transpacífico } \\
\hline Câmara dos Deputados & $4047-10$ & 2006 & 77 & 19 \\
\hline Senado & $4047-10$ & 2006 & 30 & 4 \\
\hline
\end{tabular}

3.6 atendem ao critério de seleção de no mínimo $10 \%$ de divergência nas votações, e, por essa razão, apenas aquelas destacadas em negrito entraram na análise.

Para averiguar as hipóteses previamente estabelecidas e dar conta da mensuração do distrito 
eleitoral, dá-se atenção a duas variáveis: Pop Distrital e Número de Distritos. Como no Chile não há diferença na magnitude distrital entre deputados - cada distrito elege 2 deputados - e entre senadores - cada circunscrição elege 2 senadores -, para se comparar o comportamento dos legisladores levando em consideração o tamanho dos distritos, é possível recorrer à variação da população nos distritos e circunscrições. Para deputados, esse número pode variar entre 32 mil e 712 mil habitantes. Para senadores, entre 50 mil e 3 milhões de habitantes. Ao se testar o modelo com uma amostra reduzida a senadores, além de se utilizar a variação populacional, pode-se recorrer à variação do número de distritos dentro das circunscrições, pois em cada circunscrição pode haver um número de 2 a 8 de distritos, o que poderia ser considerado uma proxy para o grau de heterogeneidade encontrada nas áreas geográficas. Assim, de acordo com a perspectiva teórica apresentada, espera-se que, primeiro, quanto maior a população nos distritos e circunscrições, maior a probabilidade de o parlamentar vinculado ao distrito ou circunscrição apoiar medidas liberalizantes. No caso de se trabalhar apenas com senadores, além de se utilizar a população, recorre-se também ao número de distritos dentro das circunscrições.

Tabela 3.7: Estatística Descritiva I, Chile

\begin{tabular}{llrrr} 
Variáveis & Níveis & n & $\%$ & $\sum \%$ \\
\hline Voto & Contra & 229 & 9.9 & 9.9 \\
& A Favor & 2082 & 90.1 & 100.0 \\
\hline Legislador & Dotal & 2311 & 100.0 & \\
\hline & Senutado & 1931 & 83.6 & 83.6 \\
& Total & 2311 & 100.0 & \\
\hline \hline Partido Político & ind & 240 & 10.6 & 10.6 \\
& PDC & 301 & 13.3 & 23.9 \\
& PPD & 138 & 6.1 & 30.0 \\
& PRSD & 4 & 0.2 & 30.1 \\
& PS & 38 & 1.7 & 31.8 \\
& RN & 684 & 30.2 & 62.0 \\
& UCCP & 60 & 2.6 & 64.7 \\
& UDI & 801 & 35.4 & 100.0 \\
\hline Total & 2266 & 100.0 & \\
\hline \hline
\end{tabular}

Outra variável política relevante é Partido, na qual se codificam os partidos políticos representados no Parlamento chileno, além dos independentes: Partido Democrata Cristão (PDC); 
Partido Pela Democracia (PPD); Partido Radical Social Democrata (PRSD); Partido Socialista (PS); Renovação Nacional (RN); União Democrática Independente (UDI); e União de Centro Centro Progressista (UCCP). Por fim, para controlar por fatores econômicos, informa-se Renda, que diz respeito a renda per capita; Desemprego, para taxa de desemprego local; e níveis de emprego no setor primário, secundário e terciário. No que diz respeitos aos dados sociais e demográficos ${ }^{8}$, apresenta-se o Índice de Desenvolvimento Humano (IDH), que congrega expectativa de vida, nível educacional e Produto Interno Bruto (PIB), e Pop Urbana, que dá conta do nível de urbanização de distritos e circunscrições. As estatísticas descritivas estão dispostas nas Tabelas 3.7 e 3.8 .

Tabela 3.8: Estatística Descritiva II, Chile

\begin{tabular}{lrrrr}
\hline \hline Variável & Média & Desvio Padrão & Min & Max \\
\hline Pop Distrital & 319382.97 & 358827.73 & 32912.00 & 2974692.00 \\
Desemprego & 13112.17 & 16633.92 & 1002.00 & 140023.00 \\
IDH & 0.72 & 0.05 & 0.62 & 0.93 \\
Renda & 455200 & 51042 & 357000 & 679700 \\
Emprego Setor Agrário & 16.76 & 12.26 & 0.90 & 44.20 \\
Pop Urbana & 82.89 & 16.93 & 42.00 & 100.00
\end{tabular}

\subsubsection{Resultados}

Na Tabela 3.9, são apresentados os resultados das estimações das características do distrito sobre a preferência comercial dos legisladores chilenos. No Modelo 1, no qual se inserem as votações de deputados e senadores, e se adiciona uma variável dummy para indicar o efeito separado de senadores, pode-se testar as duas hipóteses - o efeito do tamanho do distrito e o impacto da votação de senadores vis-à-vis deputados. De acordo com os coeficientes do Mod-

${ }^{8}$ Os dados foram obtidos junto ao Instituto Nacional de Estatísticas do Chile, www. ine.cl/ e no website da Biblioteca do Congresso Nacional, na seção de dados desagregados por distritos e circunscrições, http://reportescomunales.bcn.cl/2013/index.php/P\%C3\% A1gina_principal. Parte deles, com respaldo na Lei de Acesso à Informação, pedido número AH007W-0009497. 
elo 1, Pop Distrital e Senador, as variáveis de interesse, são estatisticamente significantes; no entanto, a direção dos sinais contradiz a teoria indicada nas hipóteses. Enquanto o primeiro está de acordo, ou seja, quanto maior a população distrital, maior a probabilidade de se votar favoravelmente em medidas de livre-comércio, o fato de se tratar de senador diminui a inclinação do parlamentar para apoiar esse tipo de política. Mais especificamente, para cada mudança unitária na variável Pop Distrital, o log de chance de apoiar medidas favoráveis ao livre-comércio aumenta 0.5. Em termos de razão de chance, é possível afirmar que, a cada 1.000 habitantes adicionais por distrito, a razão de chance aumenta por um fator de 1.03. Para a condição de senador, o log de chance de apoiar medidas favoráveis ao livre-comércio diminui 1.03. Em termos de razão de chance, é possível afirmar que, pelo fato de ser senador, a razão de chance diminui por um fator de 0.357 .

Um achado já esperado do Modelo 1 diz respeito aos coeficientes relativos aos partidos políticos. Tomando como categoria de referência legisladores considerados independentes sem partidos -, e com exceção do Partido Socialista (PS) e Renovação Nacional, todos os outros resultados são estatisticamente significantes, corroborando resultados já apontados pela literatura. Além do mais, com exceção de Pop Urbana, nenhuma das outras variáveis de controle - econômicas, sociais e demográficas - mostrou-se estatisticamente significante.

Também na Tabela 3.9, encontram-se os resultados da estimação do voto parlamentar separado entre deputados e senadores. Nos dois modelos - Modelo 2 e Modelo 3 -, testa-se, primordialmente, o efeito do tamanho dos distritos sobre o voto relativo ao livre-comércio. No caso do primeiro, para senadores, levando em consideração a população e o número de distritos por circunscrições; no seguinte, apenas para deputados, e levando em consideração apenas a população distrital. Em ambos, as variáveis explicativas primárias não possuem efeito. Os efeitos dos partidos políticos, no entanto, foram mantidos, conforme o Modelo 1.

Pode-se afirmar, portanto, que os resultados informados na Tabela 3.9 indicam que a abor- 
Tabela 3.9: Resultado Regressão, Chile

\begin{tabular}{|c|c|c|c|}
\hline & \multicolumn{3}{|c|}{ Voto Livre-comércio } \\
\hline & Model 1 & Model 2 & Model 3 \\
\hline $\log ($ Pop Distrital $)$ & $\begin{array}{c}0.526^{* *} \\
(0.268)\end{array}$ & $\begin{array}{c}1.956 \\
(1.264)\end{array}$ & $\begin{array}{c}0.405 \\
(0.287)\end{array}$ \\
\hline Senador & $\begin{array}{r}-1.040^{*} \\
(0.544)\end{array}$ & & \\
\hline N.de Distritos & & $\begin{array}{r}-0.260 \\
(0.352)\end{array}$ & \\
\hline PDC & $\begin{array}{l}1.053^{* * *} \\
(0.321)\end{array}$ & $\begin{array}{c}0.317 \\
(1.232)\end{array}$ & $\begin{array}{r}0.566^{*} \\
(0.332)\end{array}$ \\
\hline PPD & $\begin{array}{l}1.416^{* * *} \\
(0.445)\end{array}$ & $\begin{array}{c}0.680 \\
(1.681)\end{array}$ & $\begin{array}{c}0.956^{*} \\
(0.488)\end{array}$ \\
\hline PS & $\begin{array}{c}15.131 \\
(341.386)\end{array}$ & $\begin{array}{c}15.108 \\
(915.211)\end{array}$ & \\
\hline $\mathrm{RN}$ & $\begin{array}{c}0.357 \\
(0.244)\end{array}$ & $\begin{array}{r}-1.650 \\
(1.250)\end{array}$ & $\begin{array}{c}0.444^{*} \\
(0.256)\end{array}$ \\
\hline UCCP & $\begin{array}{c}0.519 \\
(0.498)\end{array}$ & $\begin{array}{c}-3.739^{* *} \\
(1.889)\end{array}$ & $\begin{array}{l}1.035^{*} \\
(0.604)\end{array}$ \\
\hline UDI & $\begin{array}{c}0.484^{*} \\
(0.254)\end{array}$ & $\begin{array}{r}-2.384^{*} \\
(1.357)\end{array}$ & $\begin{array}{c}0.681^{* *} \\
(0.272)\end{array}$ \\
\hline $\log ($ Pop Urbana $)$ & $\begin{array}{c}0.021^{* *} \\
(0.009)\end{array}$ & $\begin{array}{c}0.027 \\
(0.053)\end{array}$ & $\begin{array}{l}0.019^{\text {** }} \\
(0.009)\end{array}$ \\
\hline $\log ($ Desempregados $)$ & $\begin{array}{c}-0.258 \\
(0.226)\end{array}$ & $\begin{array}{c}-0.977 \\
(0.840)\end{array}$ & $\begin{array}{c}-0.105 \\
(0.237)\end{array}$ \\
\hline IDH & $\begin{array}{c}-5.572 \\
(6.391)\end{array}$ & $\begin{array}{c}12.372 \\
(39.012)\end{array}$ & $\begin{array}{c}-5.911 \\
(6.759)\end{array}$ \\
\hline $\log ($ Renda $)$ & $\begin{array}{c}1.431 \\
(2.917)\end{array}$ & $\begin{array}{c}2.044 \\
(14.300)\end{array}$ & $\begin{array}{c}1.680 \\
(3.112)\end{array}$ \\
\hline Emprego Setor Agrário (\%) & $\begin{array}{c}0.009 \\
(0.129)\end{array}$ & $\begin{array}{c}-0.363 \\
(1.391)\end{array}$ & $\begin{array}{c}-0.008 \\
(0.139)\end{array}$ \\
\hline Constante & $\begin{array}{c}-0.661 \\
(5.551)\end{array}$ & $\begin{array}{c}0.614 \\
(39.709)\end{array}$ & $\begin{array}{c}-0.682 \\
(5.763)\end{array}$ \\
\hline $\mathrm{N}$ & 2132 & 201 & 1931 \\
\hline Log Likelihood & -672.351 & -80.621 & -576.370 \\
\hline
\end{tabular}

${ }^{* * *} \mathrm{p}<.01 ;{ }^{* *} \mathrm{p}<.05 ;{ }^{*} \mathrm{p}<.1$ 
dagem teórica do tamanho do distrito, a princípio, dificilmente se aplica ao caso chileno assim como não teve efeito no caso brasileiro. Primeiro, os resultados foram contraditórios: por um lado, foi possível encontrar evidências de que, quanto maior o distrito eleitoral, medido por meio da população distrital, maior seria o suporte dado por legisladores a medidas liberalizantes, conforme previsto na Hipótese 1; por outro, o contrário foi identificado para o caso de senadores, que são menos favoráveis ao livre-comércio do que Deputados, ao contrário do especificado na Hipótese 2. Ao mesmo tempo, em modelos complementares, nenhum dos efeitos indicados foram identificados.

\subsection{Implicações Para Literatura de EPI}

À luz da análise das votações nominais sobre matérias comerciais no Brasil e no Chile, não foi possível encontrar indícios da validade da Constituency Size Theory, um importante e fundamental pressuposto da literatura que pesquisa o impacto das regras eleitorais sobre o fenômeno do protecionismo comercial. Neste capítulo, foram testadas duas hipóteses, que, se confirmadas, atestariam indícios da já citada teoria. A primeira indica que, quanto maior o distrito eleitoral, maior será o apoio a medidas favoráveis ao livre-comércio por parte dos deputados; a segunda, que senadores são mais propensos a votar favoravelmente em matérias que versam sobre livre-comércio do que deputados.

O processo de avaliação das hipóteses diferiu sensivelmente entre os dois casos, em razão de acesso a dados e do próprio desenho institucional de casa país; no entanto, considera-se que foram os mais próximos possíveis e podem ser equiparados. Assim sendo, no caso brasileiro, levando-se em consideração medidas distintas do tamanho do distrito para deputados, chegouse à conclusão distinta: deputados em distritos menores, e, consequentemente, mais homogêneos, mostraram-se mais propícios a votarem a favor de medidas liberalizantes; corroborando o achado, senadores, que necessitam de base eleitoral mais ampla que deputados, são consider- 
avelmente mais protecionistas.

No caso chileno, as evidências foram menos claras em direção a um padrão. Por um lado, deputados e senadores em distritos mais populosos tendem a votar favoravelmente ao livrecomércio, confirmando umas das predições teóricas; por outro lado, senadores apresentam tendência protecionista em relações aos deputados. Além do mais, em modelos isolando as votações de deputados e senadores, nenhuma evidência foi encontrada. Nesse caso, as evidências mais refutam do que corroboram as hipóteses propostas.

Os achados, apesar de não confirmarem as hipóteses levantadas, convergem com os estudos de Karol (2007) e Ehrlich (2009) no sentido de destacar e reforçar a fragilidade empírica da teoria do tamanho do distrito - Constituency Size Assumption. O fato de se trazer à tona mais evidências que contrariam tal perspectiva teórica coloca em cheque trabalhos que buscam explicar a relação entre representação política e protecionismo comercial dependendo fortemente da presunção da validade do mecanismo do tamanho do distrito. Por essa razão, é necessário apresentar novas abordagens, mais realistas e empiricamente robustas, para dar conta do fenômeno. Adicionalmente, e ao contrário de Karol e Ehrlich, os resultados aqui encontrados não somente refutam a teoria, mas indicam um padrão consistente e contrário. 


\section{Capítulo 4}

\section{Desproporcionalidade e Proteção Comercial}

Diante da constatação da falta de teoria mais sofisticada que dê conta, de forma eficiente, da relação entre sistemas de representação e protecionismo, este capítulo é dedicado à apresentação de explicação alternativa à prevalecente na literatura, que adota, basicamente, a abordagem da Constituency Size Assumption, conjugada com seus desdobramentos, e à avaliação empírica da sua validade. Assim, recorre-se ao modelo Stigler-Peltzman (S-P) de regulação, ainda pouco mobilizado em combinação com instituições eleitorais, para a compreensão da dinâmica da proteção comercial tarifária.

De forma resumida, pode-se afirmar que a abordagem do modelo S-P informa que, quanto maior a responsividade dos votos em uma eleição democrática, maior a probabilidade de implementação de políticas pró-consumidores. Para a avaliação empírica, deixa-se de lado a clássica distinção dicotômica entre sistemas majoritário e proporcional, recorrendo-se à relação entre cadeiras-votos, mensurada por meio do IDE. Fazendo uso do IDE, pode-se dar conta da responsividade dos sistemas políticos e testar hipótese central da seção, qual seja, que democracias com alto nível de desproporcionalidade eleitoral estariam mais propensas a apresentar viés favorável às preferências de consumidores e, consequentemente, menores níveis de proteção comercial. Os indícios encontrados por meio da aplicação de desenho de pesquisa observacional com 37 democracias entre os anos de 1995 e 2008 corroboram a hipótese. Nas 
seções subsequentes, apresenta-se, em detalhes, a aplicação do modelo S-P para a análise da política comercial; em seguida, discute-se a escolha das variáveis dependentes e independentes de interesse. Por fim, reporta-se a metologia para a estimação dos modelos e são discutidos os resultados obtidos à luz da literatura recente.

\subsection{O Modelo Stigler-Peltzman de Regulação e Barreiras Comerciais}

O modelo de regulação desenvolvido por Stigler (1971) se apoia fortemente na teoria da ação coletiva e sustenta que, baseado nesta lógica, o governo, que assume a figura do regulador, favoreceria produtores em detrimento de consumidores, restringindo-se à análise do lado da demanda dos benefícios regulatórios. Peltzman $(1976,1989)$ estende o modelo de Stigler, concedendo maior atenção ao lado da oferta da regulação, desenvolvendo uma abordagem por meio da qual os reguladores - políticos, mais especificamente, legisladores - ponderam os interesses de produtores e consumidores com o intuito de maximizar tanto o financiamento de campanhas como o número de votos. Aproveitando a estrutura dos modelos de regulação formulados tanto por Stigler como por Peltzman - o Modelo S-P -, Chang et al. (2010) buscam adaptá-los, inserindo elemento que pretende determinar a razão pela qual o governo - reguladores - irá optar por beneficiar produtores ou consumidores. No caso, esse elemento seria o sistema eleitoral.

Em trabalho recente, mas que representa o resultado compilado de um de uma série de artigos publicado pelos autores em anos anteriores (Linzer and Rogowski, 2008; Rogowski, Chang and Kayser, 2008; Rogowski and Kayser, 2002), Chang et al. (2010) buscam explicar uma das mais intrigantes distinções econômicas entre países: a variação de preços. De acordo com os autores, as razões para o fenômeno recaem sobre uma série de fatores, passando por diferenças em níveis de regulação até questões sócio-econômicas. Parte da variação de preços é explicada por características específicas de cada país; no entanto, causa comple- 
mentar poderia ser encontrada em um componente sistemático. Nesse sentido, argumentam que diferenças relacionadas às instituições políticas, mais especificamente, às regras eleitorais adotadas por países democráticos, representam um elemento chave nessa equação. Assim, as regulações eleitorais, vistas como as regras do jogo, podem apresentar um viés, favorecendo ora produtores, ora consumidores. Quando o primeiro é favorecido, os preços subiriam; quando o segundo é favorecido, seriam reduzidos. Os autores informam que existiria uma disputa política entre dois grupos: produtores, que buscam uma precificação próxima a de monopólios; e consumidores, que demandam preços competitivos. Nesse cenário, políticos, que são responsáveis por estabelecer a regulação que determinará os níveis de preços, simplesmente desejam maximizar o apoio político, levando em consideração a taxa de substituição entre os dois grupos. Assim, os preços seriam um indicador de disputa política entre consumidores e produtores em uma determinada indústria $(2010,19)$.

A formalização e adaptação do modelo S-P por Chang et al. (2010) poderia ser resumida no seguinte: em democracias, governo e oposição se interessam por deter a maioria das cadeiras do Poder Legislativo e por fundos para financiar campanhas políticas. Os consumidores e produtores são considerados grupos mutuamente excludentes, e, enquanto um pode contribuir com recursos financeiros e votos - produtores -, o outro provê apenas votos - consumidores. Quando os votos dos consumidores ganham mais importância, políticos concedem atenção especial a esse grupo, aumentando o poder dos consumidores e fazendo valer suas preferências; e o mesmo ocorre com os produtores.

O mecanismo que definirá de que forma os grupos políticos irão agir diante de consumidores e produtores se encontra no sistema eleitoral; mais especificamente, na razão cadeirasvotos. Assim, informam que, quanto maior a responsividade dos votos, maior a probabilidade de implementação de políticas pro-consumidores. Na palavra dos autores,"the greater the percentage increase in seats produced by a $1 \%$ increase in votes, the more the policy will favor 
consumers and the more closely prices will approximate to zero"(2010, 24).

Os sistemas eleitorais são considerados métodos que traduzem - ou alocam - votos populares, recebidos por partidos ou candidatos, em postos políticos, mais comumente cadeiras no Parlamento ou no Executivo. Existem dois modelos ideais de regras eleitorais que se contrapõem no que diz respeito à elasticidade cadeiras-votos: o sistema majoritário e o sistema proporcional. As diferenças entre eles já foi explorada de forma exaustiva pela literatura (Borisyuk, Rallings and Thrasher, 2004; Lijphart, 1990; Taagepera, 1986; Taagepera and Grofman, 2003). Enquanto sistemas proporcionais geralmente operam com um expoente próximo de 1 no que diz respeito à referida elasticidade; sistemas majoritários normalmente operam com expoente 3 . Ou seja, se quatro partidos disputam uma eleição e cada um recebe a seguinte votação: 10, 20, 30 e 40, a respectiva distribuição de cadeiras no Congresso seria de $1 \%, 8 \%, 27 \%$ e $64 \%$, seguindo o padrão da regra majoritária. No entanto, em sistemas proporcionais, a mesma votação distribuiria as cadeiras de modo semelhante aos resultados absolutos: 10\%, 20\%, 30\%, e 40\% para cada partido. A conclusão lógica a que chegam Chang et al. (2010) é que, uma vez que sistemas majoritários exibem uma maior elasticidade cadeira-votos do que sistemas proporcionais, políticos eleitos em países sob a regulação do primeiro adotarão posições políticas mais próximas às preferências do consumidor; quando movidos por incentivos providos pelas regras proporcionais, haveria maior probabilidade de políticas mais próximas das preferências dos produtores, resultando em preços mais altos.

$\mathrm{O}$ argumento apresenta uma explicação robusta para a variação de preços. A abordagem já foi testada empiricamente pelos autores, que encontram consistentes evidências de efeito negativo e significante da regra majoritária sobre o níveis de preços em países democráticos em teste elaborado para uma amostra de 23 democracias desenvolvidas - países membros da OCDE - entre os anos de 1970 e 2000. Em termos substantivos, portanto, controlando por outros fatores, países que adotam o sistema majoritário apresentam, em média, preços reais 
$10 \%$ mais baixos do que a média entre os países da OCDE. Weinberg (2012) também testa o modelo S-P e encontra resultados similares; mas o trabalho esteve restrito a preços em um setor da economia - agricultura -, medido por meio do indicador Consumer Tax Equivalent (CTE).

Se os mecanismos identificados funcionaram de forma relativamente eficiente para explicar a variação de preços, seria natural esperar que também pudessem ser utilizados para explicar variação tarifária; inclusive de forma mais apropriada. Tarifas são mais facilmente determinadas por regulação, uma vez que podem ser estabelecidas por lei, decretos ou outros atos legislativos ou administrativos; e, ao contrário de preços, não encobrem os efeitos de outros fatores, que vão além de barreiras ao comércio, como custos de transporte, dimensão do mercado doméstico, entre outros. Por também representar uma disputa entre consumidores e produtores, é possível argumentar que não existiria impedimento de se aplicar o modelo S-P para explicar o impacto da representação política - regras eleitorais - sobre proteção comercial, apresentando explicações mais rigorosas do que as usuais e frágeis abordagens que dependem da Constituency Size Assumption.

\subsection{Mensurando Desproporcionalidade Eleitoral e Proteção Comercial}

\subsubsection{Variável Independente Primária: IDE}

O mecanismo que se pretende utilizar para explicar a relação entre representação política e proteção comercial é a elasticidade cadeiras-votos, uma propriedade dos sistemas eleitorais. Chang et al. (2010) recorrem à clássica e ampla classificação dos sistemas políticos entre majoritário e proporcional e a usam como uma proxy para esse mecanismo. Os autores justificam a escolha informando que "the real-world electoral systems we observe cluster around these two poles - MAJ and PR; and (...) "with a few exceptions, MAJ systems have considerably higher seats-votes slopes than do proportional methods of election"(2010, 19). Em princípio, a 
decisão parece ser uma parcimoniosa e eficiente solução; no entanto, é necessário estar ciente de que existem diferenças institucionais sutis entre os diversos sistemas eleitorais, e que essas vão além da classificação majoritário e proporcional.

Neste trabalho, entende-se que um meio alternativo e talvez mais eficiente e robusto para se mensurar a elasticidade cadeira-votos encontrada nos diversos sistemas eleitorais é se utilizar do IDE, também conhecido como Gallegher Index ou Índice dos Mínimos Quadrados (Gallagher, 1991), sendo determinado pela seguinte fórmula:

$$
I E D=\sqrt{\frac{1}{2} \sum_{i=1}^{n}\left(V_{i}-S_{i}\right)^{2}}
$$

O IDE, de fato, mensura a desproporcionalidade na distribuição entre votos e cadeiras que um determinado partido recebe em uma disputa eleitoral, sendo a soma do quadrado da diferença entre os votos recebidos e a porcentagem das cadeiras obtidas, variando entre 0 e 100 . Para exemplificar seu cálculo, suponha que em um país com 3 partidos políticos disputando uma eleição, o partido A obtenha 43\% dos votos, mas consiga 55\% das cadeiras disponíveis; enquanto o partido B tenha obtido $36 \%$ dos votos, e a mesma proporção das cadeiras. No entanto, o partido C, com $21 \%$ dos votos, detém $9 \%$ das cadeiras. Levando-se em consideração a fórmula do IDE, a desproporcionalidade eleitoral neste país hipotético, nesta eleição, será de 12, em um continuum de 0 a 100.

Ao examinar os dados disponibilizados por Gallagher sobre desproporcionalidade ${ }^{1} \mathrm{e}$ confrontá-los com a natureza dos sistemas eleitorais - majoritário, proporcional, ou misto ${ }^{2}-$, é possível questionar o argumento apresentado por Chang et al. (2010) para justificar a escolha

\footnotetext{
${ }^{1}$ A amostra utilizada nesta subseção é distinta da que serviu de base para a estimação dos modelos que serão apresentados adiante e tem como objetivo apenas ilustrar a relação entre os sistemas eleitorais e o IDE.

${ }^{2}$ Os sistemas eleitorais foram codificados como majoritário, proporcional e mistos de acordo com os critérios adotados por Keefer (2010) no Dataset of Political Institutions: quando os membros das duas Casas Legislativas são eleitos com base na regra majoritária, 1; quando os membros das duas Casas são eleitos pela regra proporcional, 2; nas demais situações, 0
} 
Figura 4.1: IDE e Sistemas Eleitorais

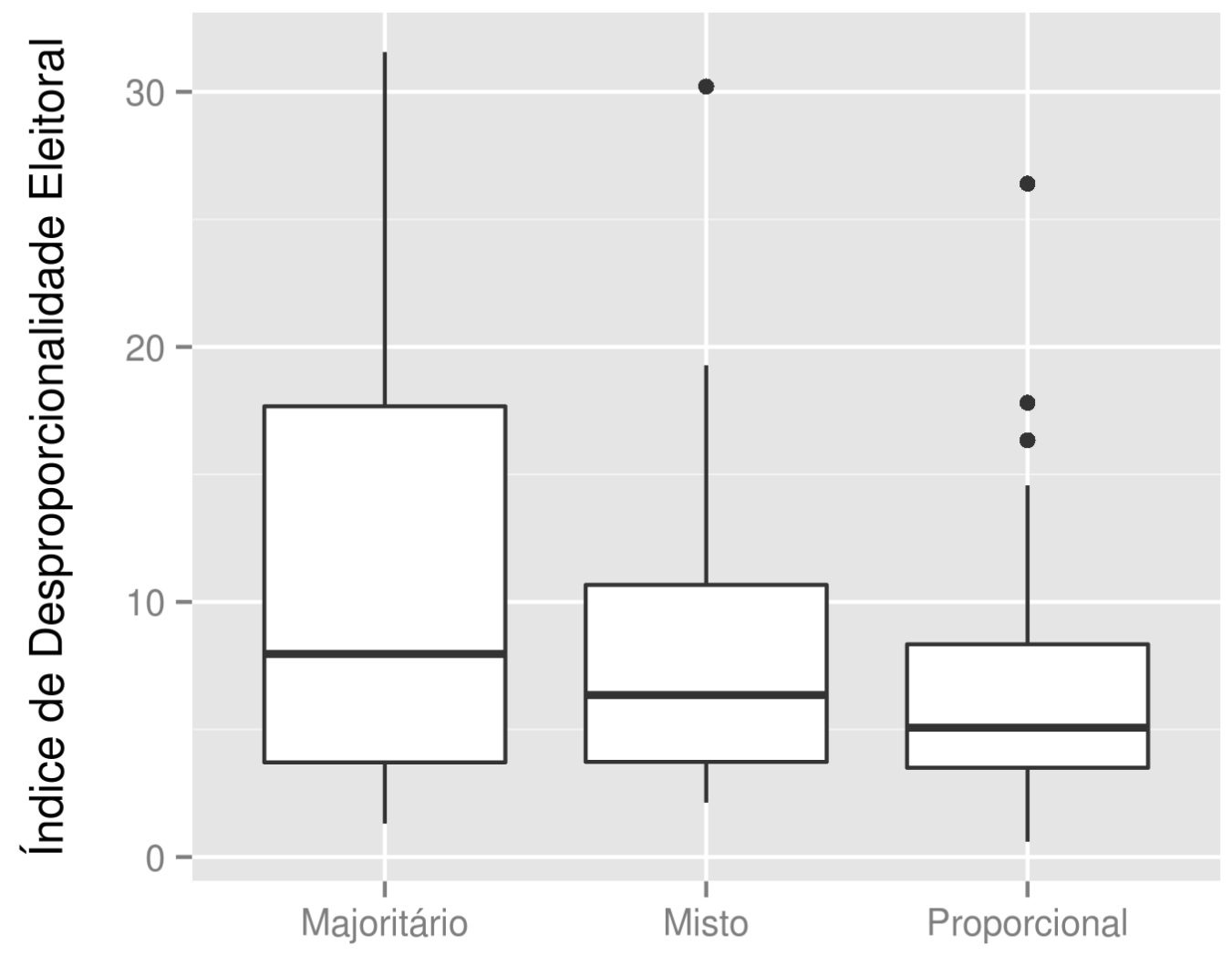

da variável independente primária e conceder mais subsídios para a decisão de se utilizar o IDE em vez da classificação majoritário-proporcional. Diante das observações de países que adotam o sistema misto (184), o majoritário (111) e o proporcional (190), existe uma média notadamente mais alta no IDE para países com sistema majoritário $(12,5)$ se comparado com mistos $(8,3)$ e proporcionais $(6,1)$; no entanto, também existe uma grande variação - desvio padrão dentro do primeiro grupo: 8,5 contra 4,5 e 5,7 para proporcionais e mistos, respectivamente. A Figura 4.1 ilustra de forma bastante clara essa distribuição.

Uma possível explicação para a variação, especialmente entre países majoritários, seriam fatores que, de acordo com a literatura de engenharia eleitoral, também determinam a responsividade das regras eleitorais, como, por exemplo, tamanho do distrito ou cláusulas de barreiras. Mesmo reconhecendo que o IDE resulta de efeito mecânico de uma série de regulações 
eleitorais, há autores que apontam outros fatores influentes, que denominam de efeitos psicológicos. Estes, por exemplo, informariam uma tendência de maior desproporcionalidade em novas democracias (Scheiner and Moser, 2012). Outro fator que pesa a favor do uso do IDE como variável independente primária em vez da classificação dicotômica, é o fato de a medida captar, de forma mais eficiente, as informações a respeito de sistemas eleitorais mistos. Na maior parte dos estudos, países que adotam sistemas mistos ou são excluídos ou são utilizados de forma ineficiente. Dessa forma, em vez de focar em instituições formais, e usá-las como proxy para a elasticidade cadeiras-votos, este estudo propõe utilizar um efeito específico gerado por essas instituições: o nível de desproporcionalidade eleitoral causado pelos sistemas eleitorais. Não resta dúvida que, dessa maneira, os resultados serão mais confiáveis do que aqueles obtidos por meio da classificação dicotômica majoritário-proporcional.

Figura 4.2: IDE em 37 Democracias entre 1995 to 2008

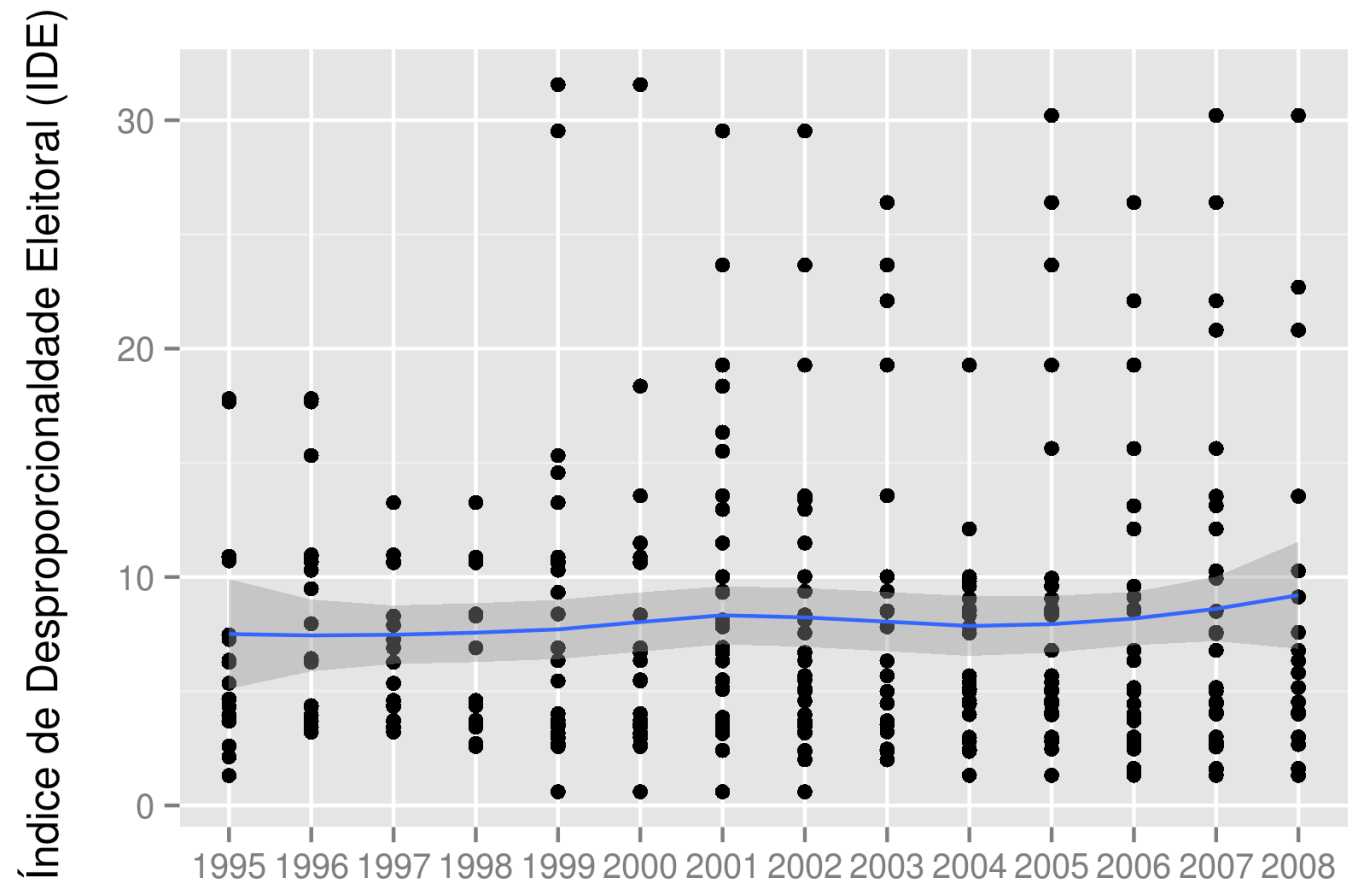

Ano 


\subsubsection{Variáveis Dependentes: Média Tarifária e Número de Picos Tar- ifários}

No que diz respeito à variável dependente, também é necessário maior esclarecimento. Assim como já explicitado, o principal objetivo é estimar impacto de determinantes políticos domésticos sobre os níveis de proteção comercial, baseado em uma teoria que informa que o nível de proteção comercial vai depender, entre outros fatores, de como o sistema político é organizado. Nesse estudo, trabalha-se com duas medidas de proteção: a média tarifária simples aplicada - the simple mean of applied tariff - e o número de picos tarifários - domésticos e internacionais -, pois há interesse tanto em explicar o nível geral de proteção retratado pelo média tarifária quanto em entender o fenômeno da proteção tarifária residual, mensurada pelo número de picos tarifários. Picos tarifários, de acordo com a OMC, são tarifas relativamente altas sobre produtos sensíveis em meio a um nível de proteção tarifária baixo, e são classificados de duas formas: como picos domésticos, quando determinada linha tarifária supera em mais de 3 vezes a média da estrutura tarifária do país; e picos internacionais, situação na qual determinada linha tarifária ultrapassa 15\% (WTO, 2012). Nesse sentido, picos tarifários são apenas um tipo de proteção residual, ou seja, aquelas tarifas que permaneceram altas mesmo após uma liberalização tarifária, sendo encontrados, normalmente, sobre itens específicos e representando uma exceção diante da padrão tarifário aplicado a outros produtos do mesmo setor ou ao nível geral de proteção.

Nesta pesquisa, dá-se especial atenção às medidas de picos tarifários, pois é sabido que, com a adoção da Rodada Uruguai na OMC, os países signatários aplicaram considerável redução na maior parte das linhas tarifárias; no entanto, ao mesmo tempo que houve uma diminuição da média tarifária, o uso de medidas protecionistas alternativas - apesar de serem também tarifária, os números de picos são tratados dessa forma pela literatura, ou seja, como proteção 
residual -, como quotas, barreiras não-tarifárias, tariff scalation, e barreiras fitossanitárias, tem apresentando aumento, ou, ao menos, uma constância, ao contrário do fenômeno ocorrido com as linhas tarifárias no começo dos anos de 1990. As Figuras 4.3 e 4.4 retratam essa situação, informando uma pequena tendência de queda da média tarifária, mas com o número de picos tarifários - domésticos - basicamente estável. Nos dois casos, é possível perceber que existe uma maior variação entre os países do que ao longo do tempo em cada país, o que pode ser observado nos Gráficos B.1, B.2, e B.3 no Apêndice B.

\section{Figura 4.3: Tarifa Média Aplicada}

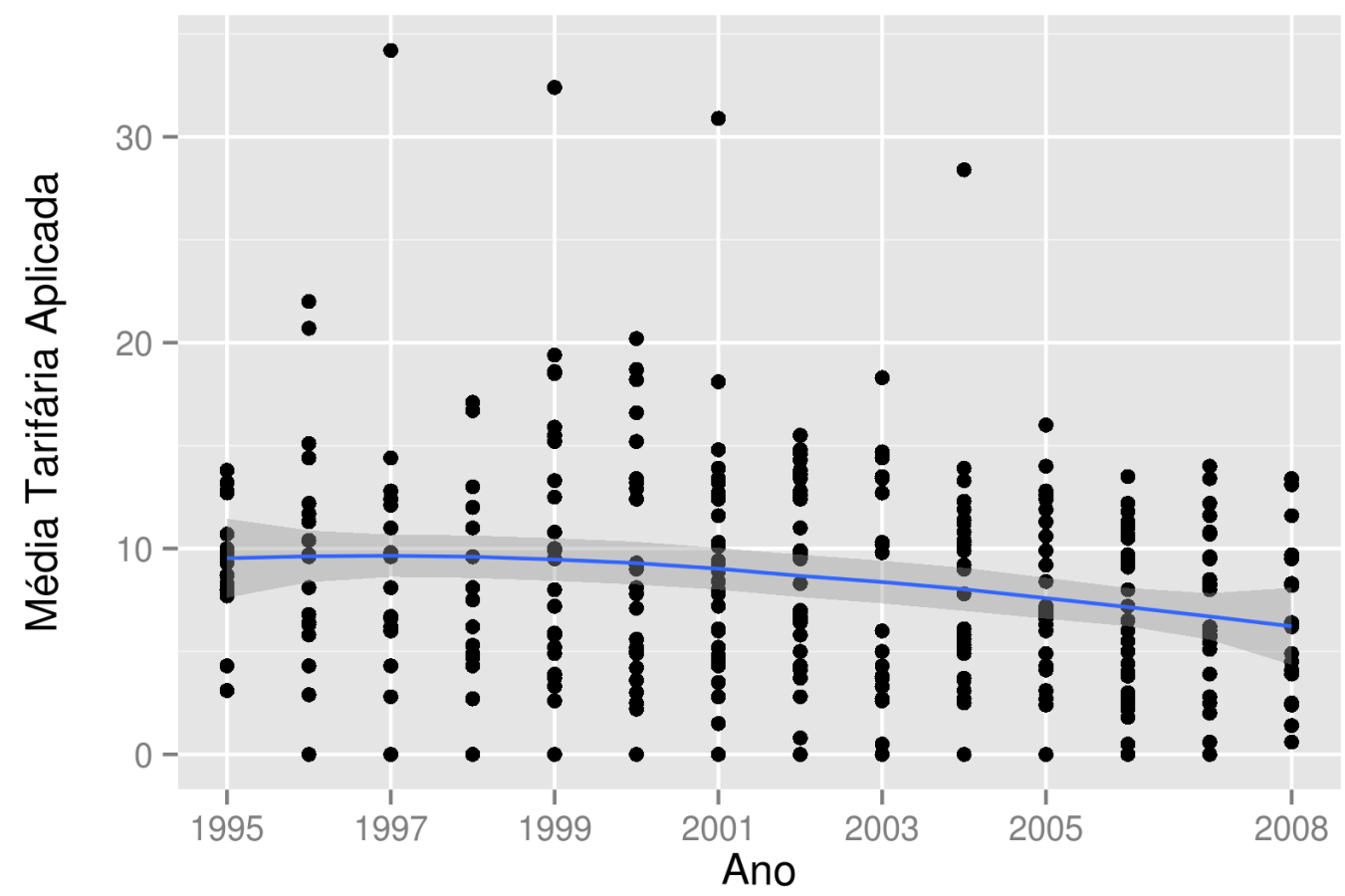

A média simples da tarifa aplicada, portanto, pode não ser a medida mais precisa para capturar o nível de proteção comercial de um país; e se basear apenas nela pode enviesar os resultados da pesquisa. Além do mais, a literatura tem apontando que países com baixo nível de proteção tarifária tendem a apresentar alto nível de proteção residual, o que pôde ser observado na Figura 4.5, confirmando as predições da Lei da Constante Proteção (Law of Constant Protection) (Mansfield and Busch, 1995). Mais interessante, contudo, é o refletir sobre as origens das 


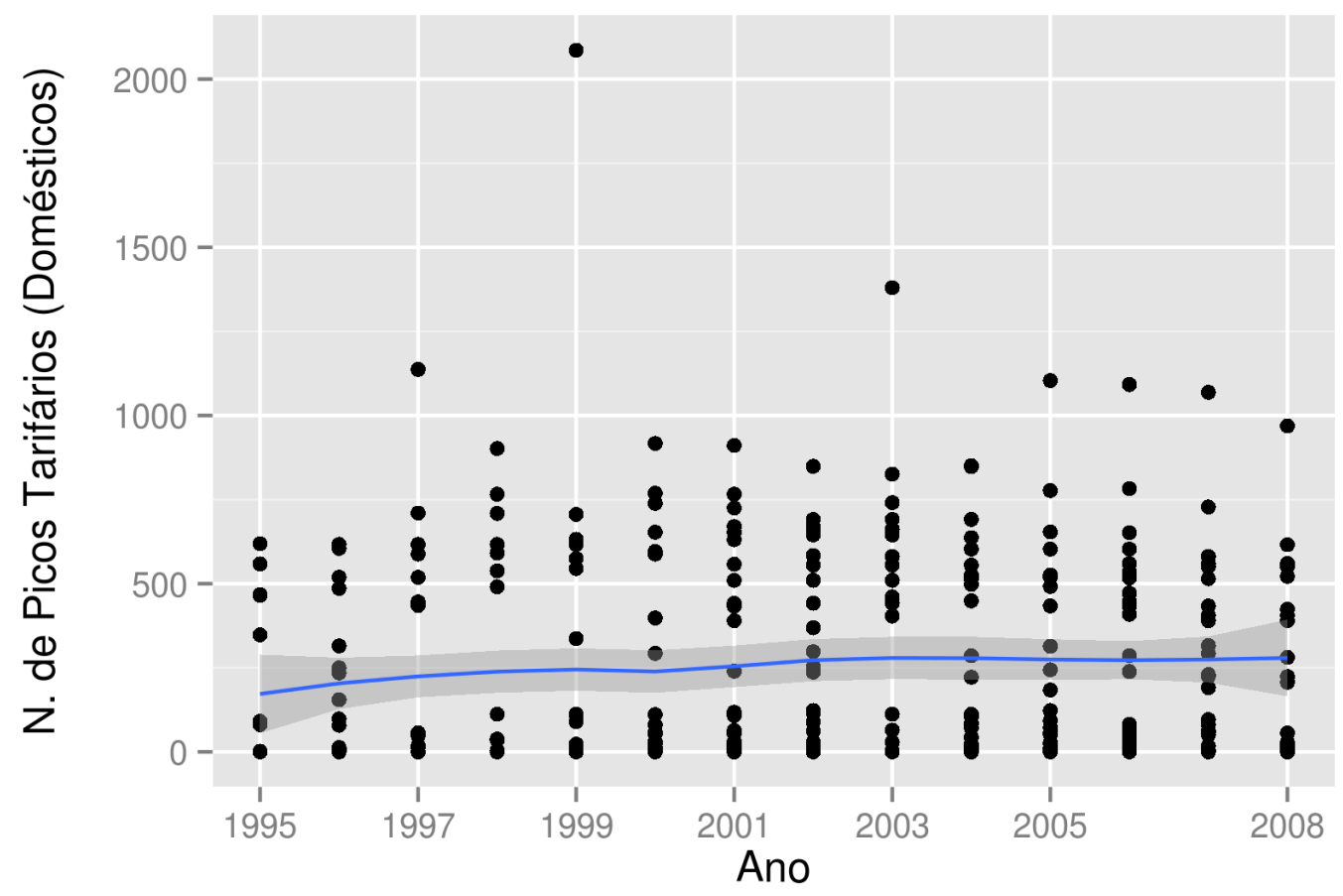

tendências mencionadas: por um lado, a queda acentuada das médias tarifárias é resultado não apenas de fatores domésticos, mas, sobretudo, representam um movimento sistêmico, obedecendo à lógica das negociações internacionais em fóruns multilaterais, que, no longo prazo, engessam a capacidade de governos nacionais de adotarem, de forma independente, suas próprias políticas; por outro lado, a proteção residual - como os picos tarifários - pode ser interpretada como pontos de resistências da ação de grupos de interesses domésticos pouco competitivos no mercado internacional, sendo que exceções, focadas em produtos sensíveis ou críticos, representam de forma mais eficiente a pressão - ou ação - dos grupos de interesses locais. Não por acaso os picos tarifários domésticos são mais concentrados em setores agrícolas em países desenvolvidos; e no setor manufatureiro, no caso dos países em desenvolvimento. Em razão destas distinções conceituais e empíricas, espera-se que os resultados relacionados aos modelos que envolvam picos tarifários sejam mais confiáveis do que aqueles que envolvam a média de tarifa aplicada. 


\subsection{Hipóteses, Metodologia e Especificação do Modelo}

\subsubsection{Hipóteses}

Recapitulando o argumento central, a conclusão derivada da análise do modelo S-P informa que, quanto maior a responsividade dos votos em uma eleição democrática, maior a probabilidade de implementação de políticas pró-consumidores, o que significa dizer menor nível de proteção comercial. A hipótese fundamental que se propõe testar nesta etapa da pesquisa informa que o IDE influenciará o nível geral de proteção comercial em países democráticos. Mais especificamente, espera-se que, quanto mais alto o IDE, mais baixo o nível de proteção. Adicionalmente, busca-se avaliar outra implicação que emerge do argumento central. A partir do momento que se reconhece que democracias presidenciais compartilham maior grau de desproporcionalidade - IDE mais alto - do que democracias não-presidencialistas, é razoável supor que países sob esse sistema de governo apresentariam níveis mais baixos de proteção. As duas afirmativas podem ser assim resumidas.

Hipótese 1: Democracias com alto nível de desproporcionalidade eleitoral apresentarão menores graus de barreiras tarifárias.

Hipótese 2: Democracias presidencialistas com alto nível de desproporcionalidade eleitoral apresentarão menores graus de barreiras tarifárias do que democracias não-presidencialistas sob as mesmas condições.

\subsubsection{Metodologia}

Para estimar o impacto do nível de desproporcionalidade eleitoral sobre o grau de proteção tarifária, recorre-se à metodologia bastante comum na área de EPI, denominada análise série temporal-coorte - time-series - cross-section (TSCS), uma vez que, neste trabalho, utiliza-se 
base de dados em formato painel, o que significa dizer que exitem informações para vários casos - um componente de coorte - e informação dos mesmos casos em vários pontos no tempo - componente temporal ou longitudinal. O método demanda a utilização de Mínimos Quadrados Ordinários (MQO) com Erro Padrão com Correção para Painel (EPCP) - panelcorrected standard errors (PCSE) - em razão da disposição dos dados.

Na análise TSCS que foi empreendida, são seguidas as recomendações que Beck e Katz demonstraram em uma série de trabalhos publicados nas últimas décadas (Beck, 2001a,b; Beck and Katz, 1995, 1996, 2011; Beck, Katz and Tucker, 1998). Um primeiro passo, no caso, é reconhecer formatação dos dados TSCS, que são frequentemente analisados em ciência política e relações internacionais. Essa disposição se caracteriza por apresentar observações repetidas - geralmente anuais - da mesma unidade de análise - geralmente países. Diferentemente da disposição de dados em formato tradicional de painel em surveys, por exemplo, que representam uma repetição de coortes, mas que resultam de amostras distintas e são observadas por poucos anos, com dados TSCS as unidades são fixas e não são reamostragens. Isso significa dizer que, no primeiro, as unidades observadas não são de interesse, mas sim a população amostral; e no segundo, toda inferência de interesse provém das unidades observadas. A notação para análise TSCS pode ser assim informada,

$$
y_{i, t}=\mathbf{x}_{i, t} \beta+\varepsilon_{i, t} ; i=1, \ldots ; t=1, \ldots T
$$

na qual $\mathbf{x}_{i, t}$ representa um vetor $\mathbf{K}$ de variáveis exógenas e as observações são indexadas tanto por unidade $(i)$ como por tempo $(t)$, com variável dependente, $y$, de forma que a série temporal deve ser longa o suficiente para validar a estimação. Neste ponto, os autores afirmam não haver uma regra quanto ao tamanho de T, mas sugerem um número próximo ou superior 
a 10 (2001b, 274). Não se demanda, no caso, um $\mathrm{N}$ grande, mas se este o for, não afetará o modelo.

Para estimação de modelos lineares com dados TSCS, sugere-se uma simples regressão com MQO. No entanto, o erro padrão gerado pelos MQO não é eficiente para o formato TSCS, pois, neste caso, viola-se o pressuposto de que a matriz é constante - os erros são não-esféricos - em razão da correlação contemporânea entre as unidades e do nível de heterogeneidade entre as unidades. A solução apresentada por Beck e Katz é a utilização do EPCP, que apresentou-se mais preciso do que aqueles gerados por meio de MQO ou por Feasible Generalized Least Squares (FGLS), técnica comumente utilizada até então pela literatura (Beck and Katz, 1995). A geração o EPCP pode ser facilmente implementada por meio de pacotes estatísticos. No caso específico deste estudo, seguem-se as diretrizes dadas por Bailey e Katz em documentação do pacote pcse para $\mathbf{R}$ (Bailey and Katz, 2011). Por fim, para lidar com a dinâmica temporal, os autores sugerem a utilização de variável dependente defasada - lagged dependent variable.

Em suma, para análise de dados em formato TSCS e com variável dependente contínua, seguindo as recomendações de Beck e Katz, deve-se, primeiro, agregar os dados das diferentes unidades - países - e um único banco de dados e estimar os parâmetros por meio do MQO. Em seguida, resolver o problema da autocorrelação - dinâmica temporal - por meio da inclusão de variável dependente defasada; e, ao final, calcular o EPCP. No entanto, diante de algumas particulares da presente base de dados utilizada, entendeu-se não ser necessário recorrer à variável defasada. Isso ocorre em razão de a base não se apresentar balanceada - há diferença na quantidade de observações por países -, e, mais importante, por haver pouca variação temporal dentro das unidades, pois, conforme já observado, as diferenças encontram-se mais acentuadas entre os países do que na linha temporal de cada país. Para complementar a análise, especialmente em decorrência do não uso de variável defasada, também se recorreu à estimação por meio de MQO Agregados - MQA, ou Pooled OLS. 


\subsubsection{Especificação}

Para mensurar a variável Proteção recorre-se à mais comum medida de proteção comercial utilizada pela literatura, que é tarifa média. No caso, utiliza-se a média tarifária simples aplicada (World Bank, 2012b). O número de picos tarifários (domésticos e internacionais) também é utilizado como variável dependente alternativa (World Bank, 2012a). A variável Presidente é uma dummy para democracias presidenciais, sendo 0 para democracias não-presidenciais que incluem parlamentaristas e semi-presidencialistas - e 1 para democracias presidencialistas. Para a variável independente primária, IDE, que mensura o nível de desproporção eleitoral, utiliza-se uma versão atualizada por Gandrud (2012) da base de dados de Gallagher ${ }^{3}$. A atualização é feita com base no trabalho de Carey and Hix (2011) .

$$
\begin{array}{r}
\text { Proteção }_{i t}=\beta_{1} I D E_{i t}+\beta_{2} \text { Presidente }_{i t}+\beta_{3}{\text { Presidente } * I D E_{i t}} \\
+\beta_{4} \text { Área }_{i t}+\beta_{5} \text { População }_{i t}+\beta_{6} \text { Região }_{i t}+\beta_{7} \text { PIB }_{i t}+\beta_{8} \text { Educação }_{i t} \\
+\beta_{9} \text { Indústria }_{i t}+\beta_{10} \text { Agricultura }_{i t}+\beta_{11} \text { Serviços }_{i t}+\varepsilon_{i t}
\end{array}
$$

As variáveis Área, População, PIB, Região, Educação, Indústria (\%), Agricultura (\%) e Serviço (\%) são controles para fatores sócio-econômicos e geográficos comumente utilizados pela literatura. Com exceção das variáveis Educação e Região, disponíveis em Gakidou et al. (2010) e Hadenius and Teorell (2005) respectivamente, as demais variáveis foram coletadas diretamente do World Development Indicators do Banco Mundial (World Bank, 2012b). A variável Educação representa o número de anos de escolaridade de homens a partir de 25 anos. Em Região, classificam-se os países de acordo com as seguintes áreas geográficas: 1) Europa

\footnotetext{
${ }^{3}$ A versão atualizada está disponível em http://www.tcd.ie/Political_Science/staff/michael_ gallagher/ElSystems/index.php

${ }^{4}$ normalsize Gandrud inclui os seguintes países: Argentina, Benin, Croácia, Colômbia, República Tcheca, Equador, Guatemala, Índia, Indonésia, Coreia do Sul, Mongólia, Filipinas, Taiwan, Tailândia, Turquia e Venezuela.
} 
Oriental e Ex-Repúblicas Soviéticas (incluindo Ásia Central); (2) América Latina (incluindo Cuba, Haiti e República Dominicana); (3) Norte da África e Oriente Médio (incluindo Israel, Turquia e Chipre); (4) África Sub-saariana; (5) Europa Ocidental e América do Norte (incluindo Austrália e Nova Zelândia); (6) Oeste Asiático (incluindo Japão e Mongólia); (7) Sudoeste Asiático; (8) Sul da Ásia; (9) Pacífico (excluindo Austrália e Nova Zelândia); (10) Caribe (incluindo Belize, Guiana e Suriname, mas excluindo Cuba, Haiti e República Dominicana). Por fim, Indústria (\%), Agricultura (\%) e Serviço (\%) representam o peso do respectivo setor sobre o PIB. O sumário estatístico das variáveis acima descritas está disponível na Tabela 4.1 e 4.2 e o resumo da especificação do modelo pode ser observado na Equação 4.3.

Tabela 4.1: Estatística Descritiva

\begin{tabular}{lrrrr} 
Variável & Média & Desvio Padrão & Min. & Máx. \\
\hline IDE & 8.0 & 6.4 & 0.6 & 31.6 \\
Tarifa & 8.4 & 5.2 & 0.0 & 34.2 \\
Número de Picos Domésticos & 255.6 & 310.0 & 0.0 & 2086.0 \\
Número de Picos Internacionais & 1497.0 & 1394.4 & 0.0 & 10898.0 \\
PIB per capita & 13679.1 & 12179.3 & 1462.8 & 49415.9 \\
Educação & 8.3 & 3.0 & 1.1 & 13.8 \\
Área & 1841360.7 & 3086006.6 & 620.0 & 9984670.0 \\
População & 66171924.7 & 162900044.8 & 147062.0 & 1140000000.0 \\
Indústria/PIB (\%) & 30.6 & 7.6 & 14.7 & 62.4 \\
Agricultura/PIB (\%) & 9.2 & 6.5 & 0.3 & 31.4 \\
Serviço/PIB (\%) & 60.3 & 8.4 & 37.0 & 77.3
\end{tabular}

No que diz respeito à seleção dos países, empregou-se o critério adotado por Przeworski et al. (2000), considerando que, no presente estudo, a análise deve ser restrita a países democráticos. Os autores fazem uso de critério dicotômico e minimalista, ao definir democracias como a system in which incumbents lose elections and leave office when the rules so dictate (2000, 24). O conceito é operacionalizado da seguinte forma: o país é considerado democrático quando (1) o Chefe do Executivo é eleito pelo voto popular; (2) o Legislativo é eleito pelo voto popular; (3) existe mais de um partido disputando o poder; (4) existe alternância no poder. Se um país não cumprir um dos requisitos, é classificado como autoritário. A versão atualizada da base de 
Tabela 4.2: Estatística Descritiva

\begin{tabular}{llrrr} 
Variável & Níveis & $\mathbf{n}$ & $\%$ & $\sum \%$ \\
\hline Presidente & Não & 137 & 41.1 & 41.1 \\
& Sim & 196 & 58.9 & 100.0 \\
\hline & Total & 333 & 100.0 & \\
\hline \hline Região & 1 & 36 & 10.8 & 10.8 \\
& 2 & 149 & 44.7 & 55.6 \\
& 3 & 7 & 2.1 & 57.7 \\
& 4 & 8 & 2.4 & 60.1 \\
& 5 & 66 & 19.8 & 79.9 \\
& 6 & 20 & 6.0 & 85.9 \\
& 7 & 9 & 2.7 & 88.6 \\
& 8 & 13 & 3.9 & 92.5 \\
& 10 & 25 & 7.5 & 100.0 \\
\hline \hline & Total & 333 & 100.0 & \\
\hline \hline
\end{tabular}

dados de Przeworski et al. (2000) é disponibilizada por Cheibub, Gandhi and Vreeland (2009). Um ponto que deve ser destacado sobre a formatação da amostra final é a exclusão dos países membros da União Europeia (UE) da presente análise, já que adotam tarifa externa comum, o que significa que existe a mesma tarifa para cada produto independente do país europeu. Nesse sentido, a inclusão da UE seria incongruente com uma base de dados cujas observações são países/ano. No caso dos países do Mercosul, apesar de também adotarem tarifa externa comum, existem diversas exceções por países, afetando a média tarifária e o número de picos tarifários de forma considerável. A amostra desse estudo reúne 37 países democráticos entre os anos de 1995 e $2008^{5}$ Na análise empírica empreendida na seção seguinte, outros critérios de seleção de países democráticos, como os aplicados pelo Freedom House e pelo Polity IV, que são amplamente mobilizados pela literatura, foram também utilizados como teste de robustez ao modelo.

${ }^{5}$ Países: Austrália, Argentina, Brasil, Bolívia, Japão, Suíça, Estados Unidos, Chile, El Salvador, Canadá, Colômbia, Indonésia, Noruega, Santa Lúcia, Uruguai, Belize, Honduras, México, Nova Zelândia, Polônia, Senegal, Trinidade e Tobago, Costa Rica, República Dominicana, Índia, Nicarágua, Venezuela, Croácia, Coreia do Sul, Macedônia, Sri Lanka, Turquia, Albânia, Bulgária, Guatemala, Moldova. 


\subsection{Análise Empírica}

O resumo dos resultados empíricos está disposto na Tabela 4.3, em que os Modelos 1, 2 e 3 se distinguem em razão do tipo de estimação - OLS/PCSE; enquanto nos modelos 4, 5 e 6 foram estimados por meio de Pooled-OLS. No modelo 1 e 3, a variável resposta é o número de picos tarifários domésticos; no modelo 2 e 4, o número de picos tarifários internacionais; e no modelo 3 e 6, a média tarifária simples aplicada. Nos seis modelos, as variáveis independentes de interesse são IDE e Presidente. Os resultados obtidos confirmam, em parte, as predições teóricas, que informam que, constantes todos os demais fatores, (1) democracias com maiores níveis de desproporcionalidade eleitoral - alto IED - apresentarão menores índices de proteção comercial; e (2) democracias presidencialistas também tendem a apresentar menores níveis de proteção do que democracias não-presidenciais.

Examinando em detalhe a Tabela 4.3, a primeira informação que se destaca é de que há efeito - de magnitude mais baixa, é verdade - do IDE sobre a média tarifária simples aplicada, como pode ser observado no modelo 3. O resultado menos expressivo era, em parte, esperado em razão do fato de a média tarifária simples aplicada ser, aparentemente, menos sensível à influência doméstica - tanto de políticas macroeconômicas como de grupos de interesses. A tendência global na direção de baixas tarifas nas últimas duas décadas foi resultado direto de negociações internacionais, que deram origem a inúmeros acordos regionais e também à emergência da OMC. Dessa forma, a maior parte dos Estados engajados nesse processo tiveram sua capacidade de atuação nas respectivas políticas comerciais diminuídas em razão dessa nova regulação internacional.

Ao mesmo tempo, quando se observam os resultados dos modelos 1 e 2 , que trazem como variável dependente número de picos tarifários domésticos e internacionais, os resultados são mais coerentes com as predições teóricas, pois entende-se que o número de picos é uma medida bastante precisa de proteção a produtos sensíveis; mostra-se estável; e é uma proxy mais con- 


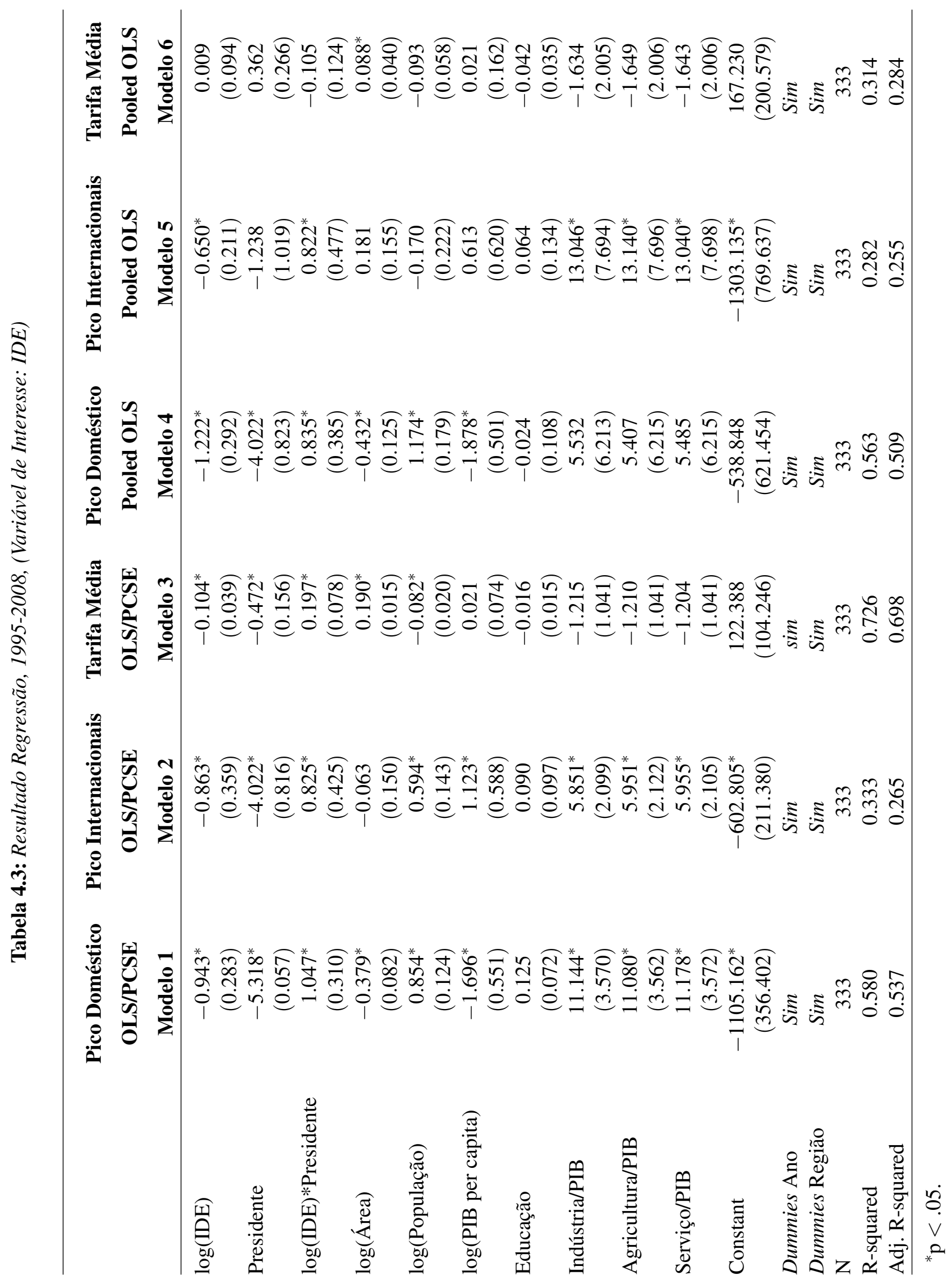


fiável para o ativismo de grupos de interesses domésticos do que outras medidas relacionadas a tarifas (VanGrasstek, 2001). Substantivamente, os modelos 1 e 2 informam resultados similares: $10 \%$ de aumento no nível de desproporção eleitoral - o IDE - representa uma redução de $8 \%$ no número de picos tarifários domésticos e de $7 \%$ no número de picos internacionais.

No que diz respeito aos efeitos dos sistemas de governo sobre os níveis de proteção comercial, apesar de a literatura já informar que democracias presidencialistas tendem a apresentar um grau mais baixo de proteção, a consistência e a magnitude dos resultados encontrados neste trabalho merecem uma atenção especial. Nos modelos 1, 2 e 3, a variável Presidente é estatisticamente significante e informa que, em democracias presidencialistas, há uma redução de mais 90\% no nível de proteção tanto para números de picos domésticos como para picos internacionais $-99 \%$ e $97 \%$ respectivamente. Democracias presidencialistas, no entanto, mostram um impacto menor, mas igualmente consistente e significante, sobre a tarifa média aplicada $-44 \%$. Esses resultados são coerentes com a tese do presidente liberal (Destler, 2005; Schattschneider, 1935); com a teoria dos pontos de acesso (Ehrlich, 2007, 2011); e com a hipótese do poder presidencial proposta por Nielson (2003). Entretanto, a explicação oferecida é distinta, pois se trata de uma mera extrapolação da formalização do modelo S-P. Assim, o mecanismo não se baseia no tamanho do distrito; no baixo custo da ação dos grupos de interesses; ou na estrutura de delegação de poderes. Considerando que presidentes são eleitos por sistemas majoritários e que o número de cadeiras é 1 , um aumento de $1 \%$ no número de votos pode representar um aumento de $100 \%$ no número de cadeiras. Em outras palavras, os votos têm mais valor em sistemas presidencialistas do que em sistemas não-presidencialistas, o que concede maior poder aos consumidores e, consequentemente, reduz o nível de proteção tarifária.

Diante das predições teóricas e os resultados empíricos para o IDE e Presidente, especialmente sobre o número de picos tarifários domésticos e internacionais reportados para os modelos 1, 2 e 3, espera-se que uma democracia presidencial com um alto nível de despropor- 
cionalidade eleitoral resulte em uma economia com baixos níveis de proteção comercial. Como retratado na Tabela 4.3, no entanto, o termo de interação Presidente* $\log ($ IDE) é estatisticamente significante, mas apresenta resultado distinto da expectativa inicial.

Ao analisar o termo de interação graficamente - Figuras 4.5, 4.6 e 4.7 -, percebe-se que o IDE não tem efeito sobre os níveis de proteção em democracias presidencialistas; no entanto, as predições teóricas são observadas em democracias não-presidenciais. Esse resultado sugere duas possíveis explicações: (1) legisladores em sistemas presidencialistas não se preocupam ou não detêm capacidade para lidar - com questões de proteção tarifária; ou (2) em sistemas presidencialistas, o próprio presidente seria um garantidor de baixas tarifas, tornando o trabalho do legislador sobre a matéria ineficiente ou desnecessário. Essa perspectiva confirma, de alguma forma, a teoria dos pontos de acesso, especialmente no contexto de presidencialismo forte. O tópico, no entanto, demanda análise mais detalhada.

No que diz respeito aos resultados obtidos da estimação com Pooled $O L S$, informados pelos modelos 4, 5 e 6 da Tabela 4.3, eles confirmam, parcialmente, aqueles encontrados, em especial quando se trata dos números de picos tarifários. Nesse sentido, os resultados são até mais coerentes com as previsões apontadas inicialmente. $\mathrm{O}$ mesmo pode ser dito das conclusões a respeito da interação entre os IDE e Presidente.

Após estimar os modelos tendo IDE como variável independente de interesse, estimam-se os mesmos modelos apresentados na Tabela 4.3, mas utilizando a classificação categórica entre os sistemas eleitorais, majoritário, proporcional e misto, em vez do IDE, pois, dessa forma, é possível comparar o impacto dos sistemas majoritário e proporcional; além do mais, avaliar, de forma indireta, a relação entre a classificação tradicional e o IDE. Tendo em vista os resultados expostos da Tabela 4.4, não foi possível captar maior efeito de majoritário sobre os níveis de proteção do que proporcional; ao contrário. Ao se examinar o número de picos tarifários domésticos e internacionais nos resultados dos modelos 1, 2, 4 e 5, é possível observar maior 
Figura 4.5: Efeitos do Termo de Interação sobre Picos Domésticos

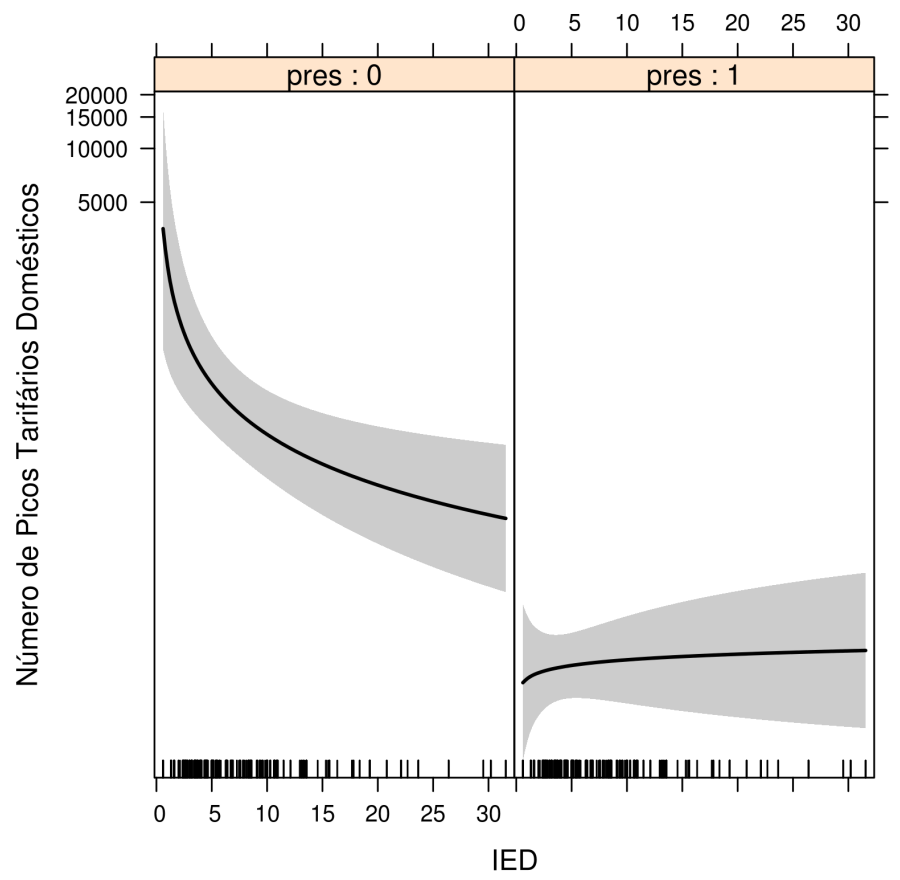

Efeitos do Termo de Interação sobre Picos Internacionais

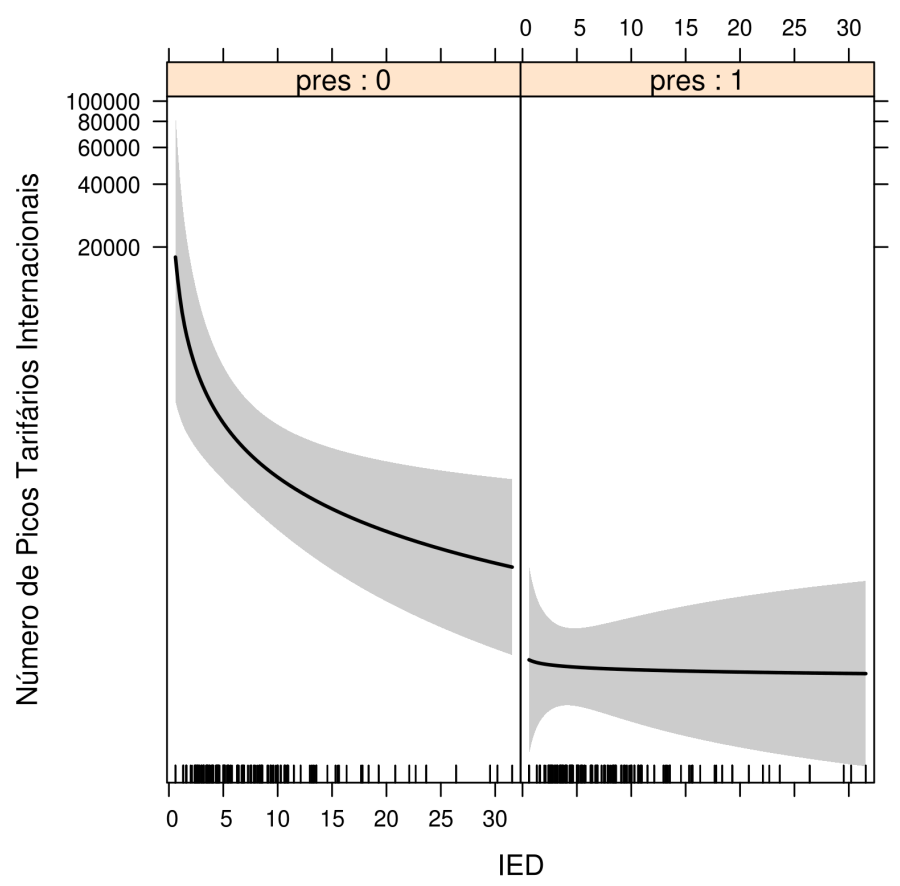

impacto do proporcional sobre o número de picos se comparado com os efeitos do sistema majoritário. No que diz respeito aos resultados sobre tarifa média aplicada nos modelos 3 e 6 , 
Figura 4.6: Efeitos do Termo de Interação sobre Tarifa Média Aplicada

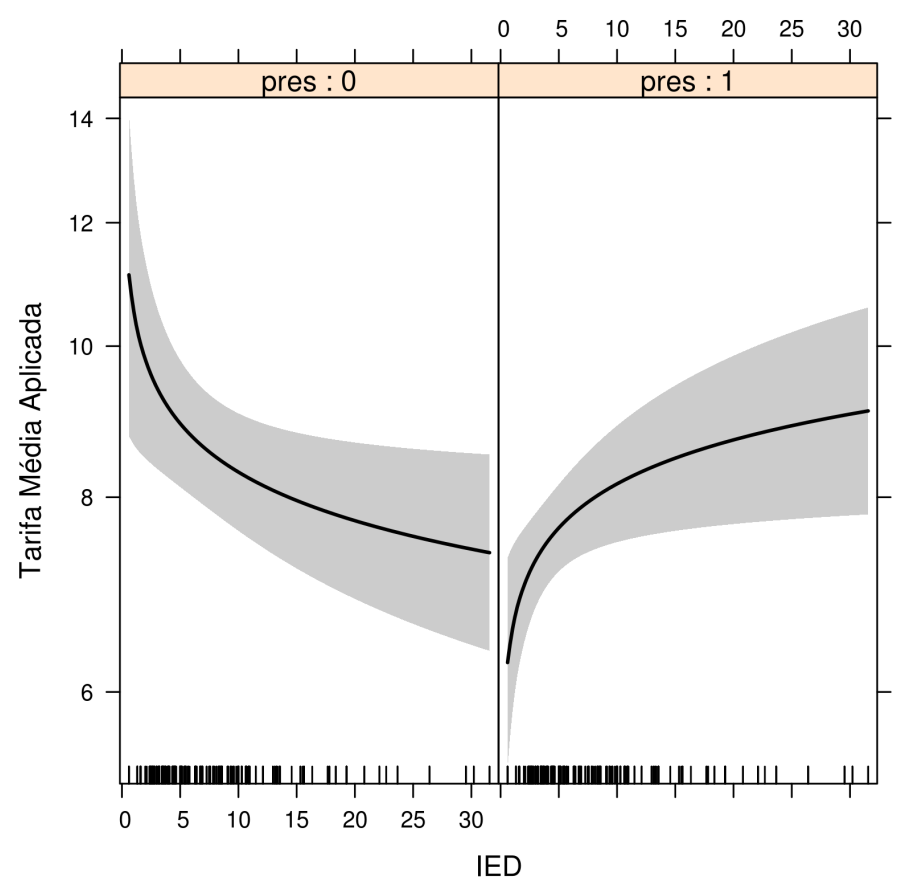

estes foram inconsistentes: o impacto de majoritário foi maior do que em os sistemas mistos; mas não foi possível compará-lo com proporcional, que se apresentou não-significante.

Por fim, efetuou-se avaliação preliminar para checar se os resultados são mantidos mesmo diante de critérios distintos para a seleção dos países democráticos: Freedom House e Polity IV. Os resultados estão reportados nas Tabelas B.1, B.2 no Apêndice B. Diante de seleção utilizando o critério Freedom House, com amostra de 29 países - 248 observações -, os resultados se mantiveram quando a variável dependente é número de picos tarifários; no caso do Polity IV, que compreendeu 37 países - 350 observações -, eles só foram consistentes quando os modelos foram estimados por meio do OLS/PCSE.

\subsection{Discussão}

Os resultados até aqui obtidos indicam a existência de uma relação distinta entre representação política e proteção comercial baseada em um mecanismo ainda pouco explorado pela 
literatura. A abordagem apresentada, calcada no modelo S-P, informa que, quanto maior a responsividade dos votos em uma eleição, maior a probabilidade de implementação de políticas pró-consumidores em países democráticos. Para representar a relação entre cadeiras-votos, recorreu-se ao IDE, com o objetivo de mensurar seu impacto tanto sobre as tarifas médias aplicadas como para o número de picos tarifários domésticos e internacionais. Neste ponto, é possível argumentar que os achados confirmam algumas das previsões teóricas e indicam que, tudo mais constante:

(1) quanto mais altos os níveis de desproporcionalidade eleitoral em democracias, maiores as chances de se apresentar menores níveis de proteção comercial.

(2) há tendência, em democracias presidenciais, a apresentar níveis mais baixos de proteção do que em democracias não-presidencialistas. O argumento, no entanto, não está baseado no tamanho do distrito, mas no nível de desproporcionalidade imposto pelas regras eleitorais. Mais interessante, os resultados apontam para uma interação entre IDE e o tipo de sistema político que ainda não foi explorada em profundidade pela literatura.

É importante ressaltar também que as conclusões iniciais vão ao encontro dos estudos elaborados por Chang et al. (2010) e Weinberg (2012), que indicam um viés pró-consumidor em sistemas eleitorais mais responsivos - mais desproporcionais. A diferença, no entanto, repousa no fato de os autores estarem avaliando o nível de preços. Diante da já comentada ausência de conclusões a respeito dos achados da literatura com base no Constituency Size Assumption, acredita-se ser relevante a convergência dos resultados obtidos com estudos mais robustos. 


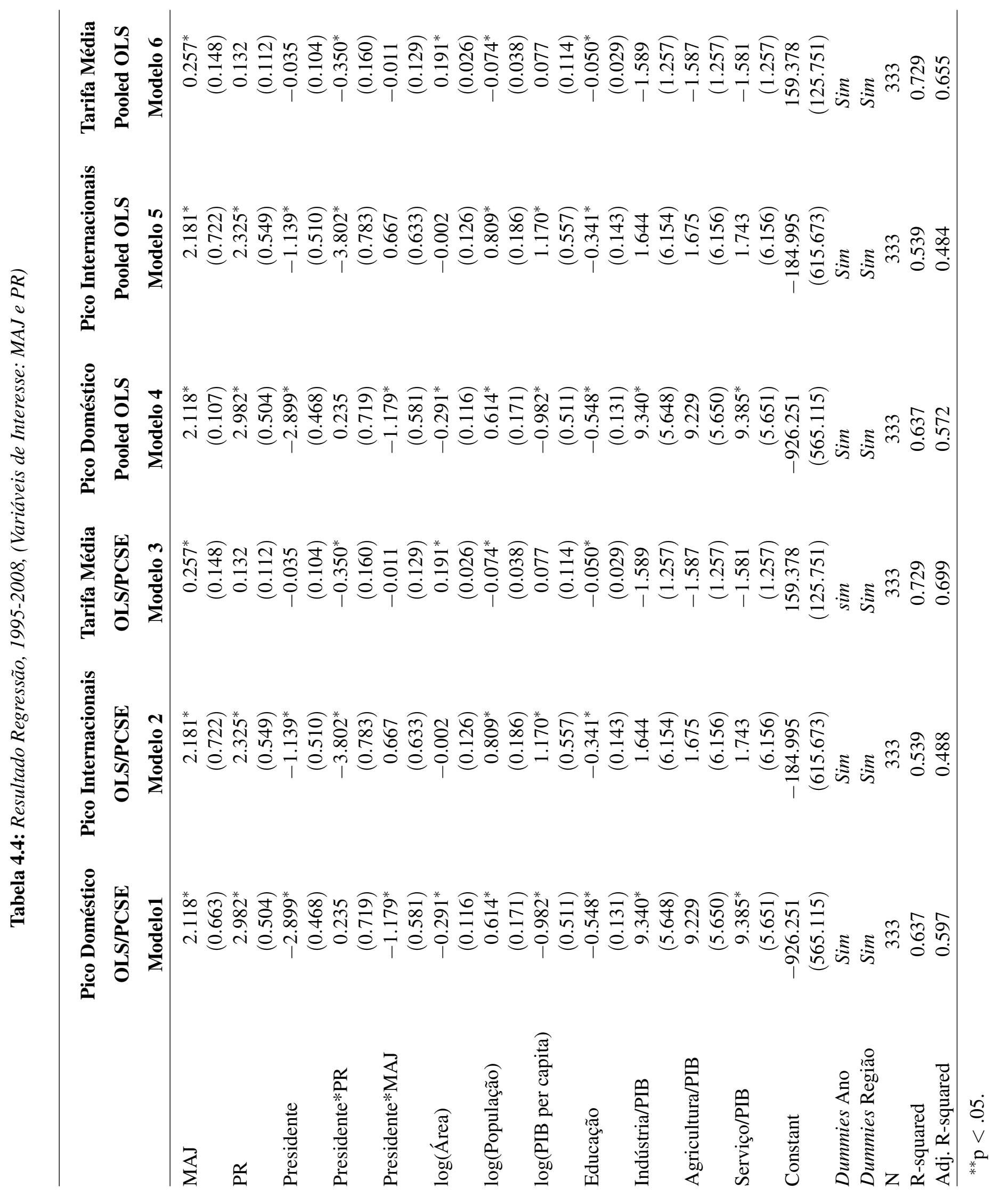




\section{Capítulo 5}

\section{Conclusão}

Diante de resultados inconclusivos e contraditórios da literatura a respeito da relação entre sistemas de representação e os níveis de proteção comercial em países democráticos, o objetivo desta tese foi abordar a questão com o intuito de suprir lacunas existentes nesses estudos. Assim, buscou-se avaliar teorias tomadas como pressupostos pela literatura e apresentar explicação alternativa, porém empiricamente robusta, para dar conta do efeito das regras eleitorais sobre o comércio.

Inicialmente, no capítulo 3, buscou-se avaliar os mecanismos causais da teoria que prevalece na literatura, a Constituency Size Assumption, a qual se contrapõe à explicação baseada na desproporção eleitoral. No capítulo 4, em contra-posição às análises que se concentram nas diferenças entre sistemas majoritários e proporcionais, e sem levar em conta a análise do suposto mecanismo causal, buscou-se apresentar explicação mais refinada do mecanismo eleitoral. Nesse sentido, apresentou-se uma adaptação do modelo Stigler-Peltzman de regulação, que informa que o mecanismo que definirá de que forma os grupos políticos irão agir diante de consumidores e produtores encontra-se no sistema eleitoral; mais especificamente, na razão cadeiras-votos. Assim, quanto maior a responsividade dos votos, maior a probabilidade de implementação de políticas pró-consumidores.

Para testar empiricamente as abordagens teóricas apresentadas, recorreu-se, no do capítulo 
3, ao estudo de dois casos, em que, primeiro, estimou-se o voto dos parlamentares em matéria comercial por meio de Estimativa por Máxima Verossimilhança. No capítulo 4, recorreu-se a um desenho de pesquisa multi-países e observacional, quando se buscou estimar o nível de proteção tarifária por meio de OLS com Erro Padrão com Correção para Painel (Panel-Corrected Standard Errors).

No capítulo 3, que trata dos efeitos do tamanho do distrito sobre as preferências do legislador em matéria livre-comércio, estes foram inconsistentes. No caso do Brasil, as duas medidas propostas para tamanho do distrito - magnitude distrital e número de eleitores - foram estatisticamente significantes e indicam o mesmo padrão. No entanto, apresentam resultados que são justamente contrários aos preditos pela teoria. Os achados indicaram, portanto, que a abordagem teórica do tamanho do distrito, a princípio, não se aplica ao caso brasileiro, pois, primeiro, não foi possível encontrar evidências de que, quanto maior o distrito eleitoral, medido por sua magnitude e pelo número de eleitores, maior seria o suporte dado por legisladores a medidas liberalizantes. Segundo, não foi possível identificar se Senadores são mais favoráveis ao livre-comércio do que Deputados.

No caso do Chile, em que também se pode testar o efeito do tamanho do distrito e o impacto da votação de senadores vis-à-vis deputados, as variáveis de interesse foram estatisticamente significantes; no entanto, a direção dos sinais contradiz a teoria indicada nas hipóteses. Enquanto o primeiro estava de acordo - ou seja, quanto maior a população distrital, maior a probabilidade de se votar favoravelmente em medidas de livre-comércio - o fato de ser senador diminui a inclinação do parlamentar a apoiar esse tipo de política.

Pode-se afirmar, portanto, que os resultados indicaram que a abordagem teórica do tamanho do distrito, a princípio, dificilmente se aplica ao caso chileno e brasileiro. Primeiro, os resultados foram contraditórios: se, por um lado, foi possível encontrar evidências de que, quanto maior o distrito eleitoral, medido por meio da população distrital, maior seria o suporte dado 
por legisladores a medidas liberalizantes, conforme previsto na Hipótese 1; por outro, o contrário foi identificado para o caso de Senadores, que são menos favoráveis ao livre-comércio do que Deputados, ao contrário do especificado na Hipótese 2. Ao mesmo tempo, em modelos complementares, nenhum dos efeitos indicados foi identificados.

No capítulo 4, os resultados confirmaram as predições teóricas, que informam que, constantes todos os demais fatores, (1) democracias com maiores níveis de desproporcionalidade eleitoral - alto IED - irão apresentar menores índices de proteção comercial; e (2) democracias presidencialistas também tendem a apresentar níveis de proteção menores do que democracias não-presidenciais.

Os modelos do capítulo 4 informam que não há efeito do IDE sobre a média tarifária simples aplicada. Uma possível explicação para esse resultado poderia ser o fato de a média tarifária simples aplicada ser, aparentemente, menos sensível à influência doméstica - tanto de políticas macroeconômicas como de grupos de interesses. A tendência global na direção de baixas tarifas nas últimas duas décadas foi resultado direto de negociações internacionais, que deram origem a inúmeros acordos regionais e também à emergência da $\mathrm{OMC}$; dessa forma, a maior parte dos Estados engajados nesse processo tiveram sua capacidade de atuação nas respectivas políticas comerciais diminuídas em razão dessa nova regulação internacional.

Ao mesmo tempo, os resultados são diferentes e, em muitos aspectos, mais coerentes com as predições teóricas quando se analisou o número de picos tarifários domésticos e internacionais, pois entende-se que o número de picos é uma medida bastante precisa de proteção a produtos sensíveis; mostra-se estável, independentemente da tendência global em direção a baixas tarifas; e é uma proxy mais confiável para o ativismo de grupos de interesses domésticos do que outras medidas relacionadas a tarifas.

Por fim, no que diz respeito aos efeitos dos sistemas de governos sobre os níveis de proteção comercial, apesar de a literatura já informar que democracias presidencialistas tendem a apre- 
sentar uma grau mais baixo de proteção, a consistência e a magnitude dos resultados encontrados neste trabalho merecem uma atenção especial. Na seção, informa-se que, em democracias presidencialistas, há uma redução significativa no nível de proteção tanto para números de picos domésticos como para picos internacionais. Democracias presidencialistas, no entanto, têm um impacto menor, mas igualmente consistente e significante, sobre a tarifa média aplicada. Esses resultados são coerentes com a tese do presidente liberal; com a teoria dos pontos de acesso; e com a hipótese do poder presidencial. Contudo, a explicação oferecida foi distinta, pois se trata de uma mera extrapolação da formalização do modelo Stigler-Peltzman. Assim, o mecanismo não se baseia no tamanho do distrito; no baixo custo da ação dos grupos de interesses; ou na estrutura de delegação. Considerando que presidentes são eleitos por sistemas majoritários e que o número de cadeiras é 1 , um aumento de $1 \%$ no número de votos pode representar um aumento de $100 \%$ no número de cadeiras. Em outras palavras, os votos têm mais valor em sistemas presidencialistas do que em sistemas não-presidencialistas, o que concede maior poder aos consumidores e, consequentemente, reduz o nível de proteção tarifária.

Esses resultados relacionados com tipo de sistema de governo e o nível de desproporção eleitoral sugerem duas possíveis explicações: (1) legisladores em sistemas eleitorais não se preocupam - ou não detêm capacidade para lidar com - com questões de proteção tarifária; ou (2) em sistemas presidencialistas, o próprio presidente seria um garantidor de baixas tarifas, tornando o trabalho do legislador sobre a matéria ineficiente ou desnecessário. Essa perspectiva confirma, de alguma forma, a teoria dos pontos de acesso, especialmente no contexto de presidencialismo forte. O tópico, no entanto, demanda análise mais detalhada. 
Apêndice A 


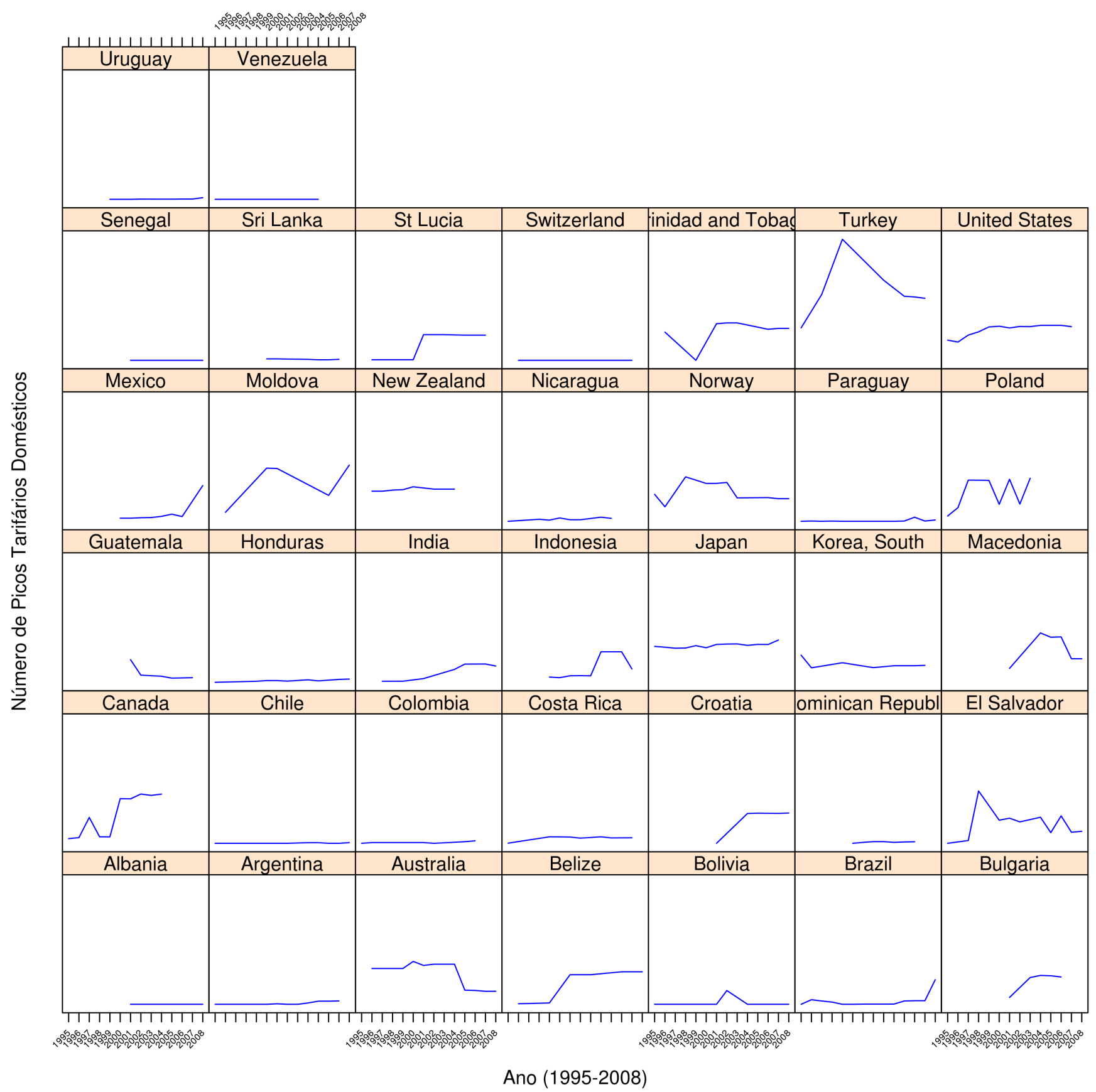

Gráico B.1: Número de Picos Tarifários Domésticos por país, 1995-2008 


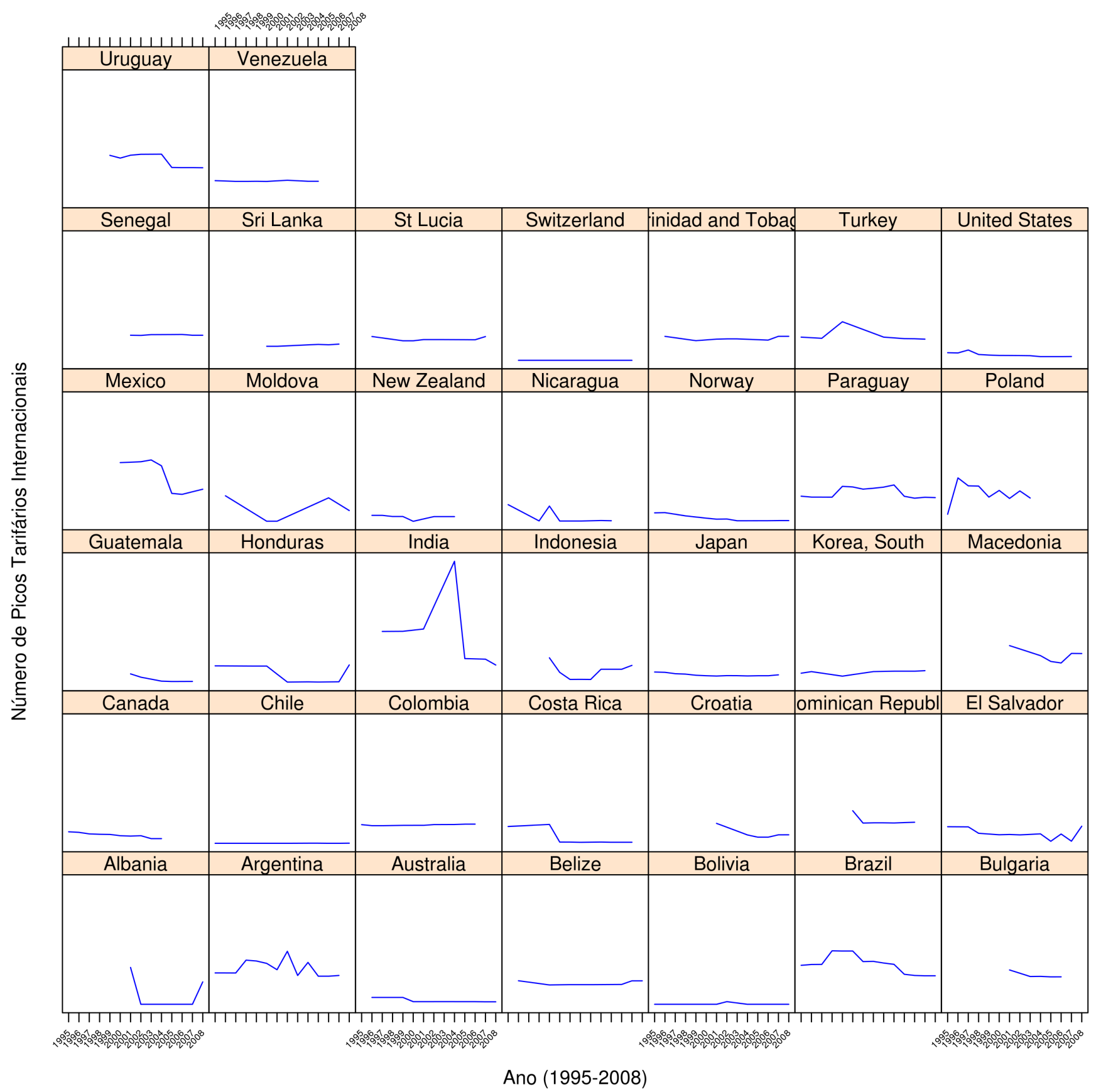

Gráfico B.2: Número de Picos Tarifários Internacionais por país, 1995-2008 


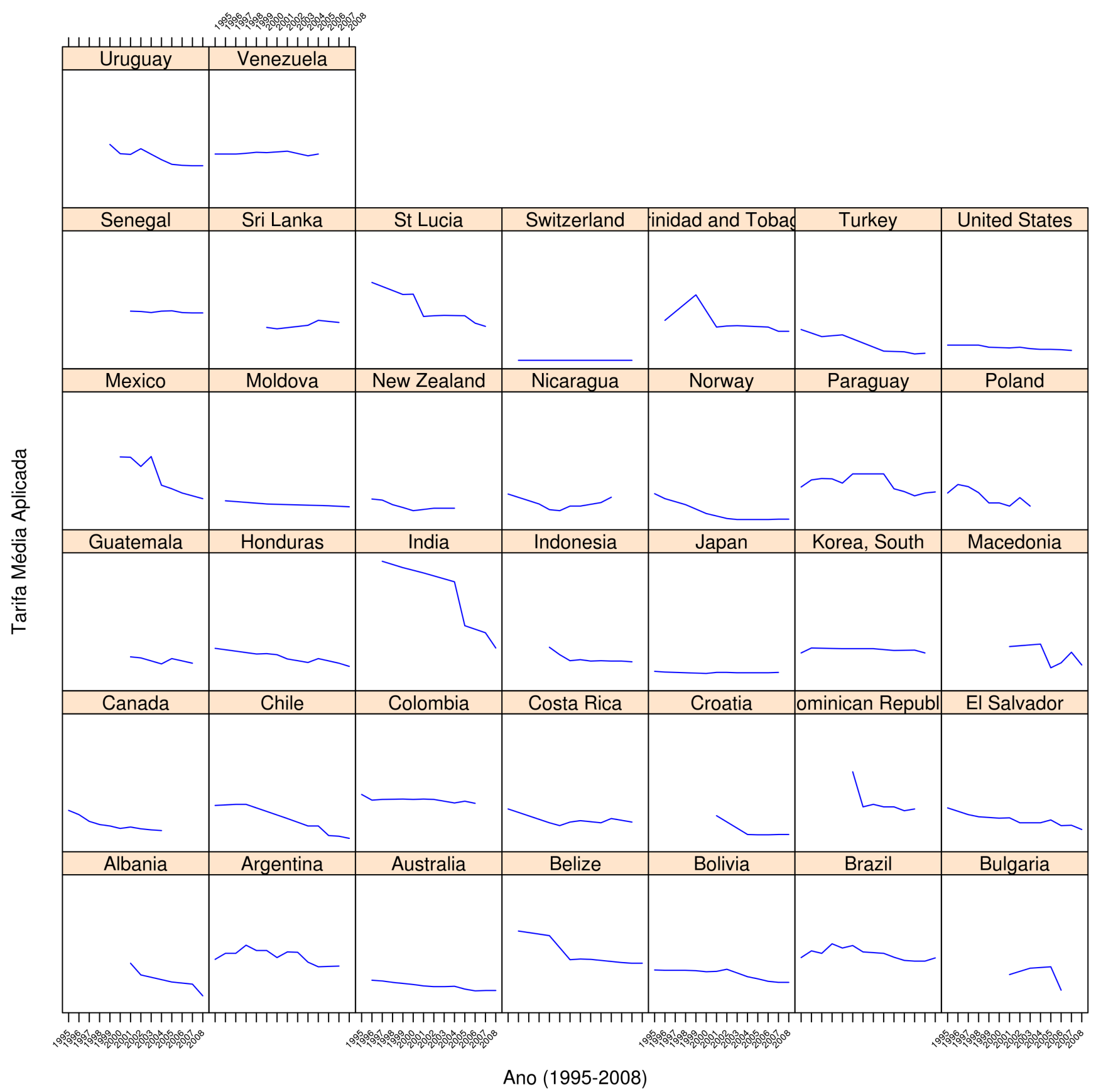

Gráfico B.3: Tarifa Média Aplicada por país, 1995-2008 


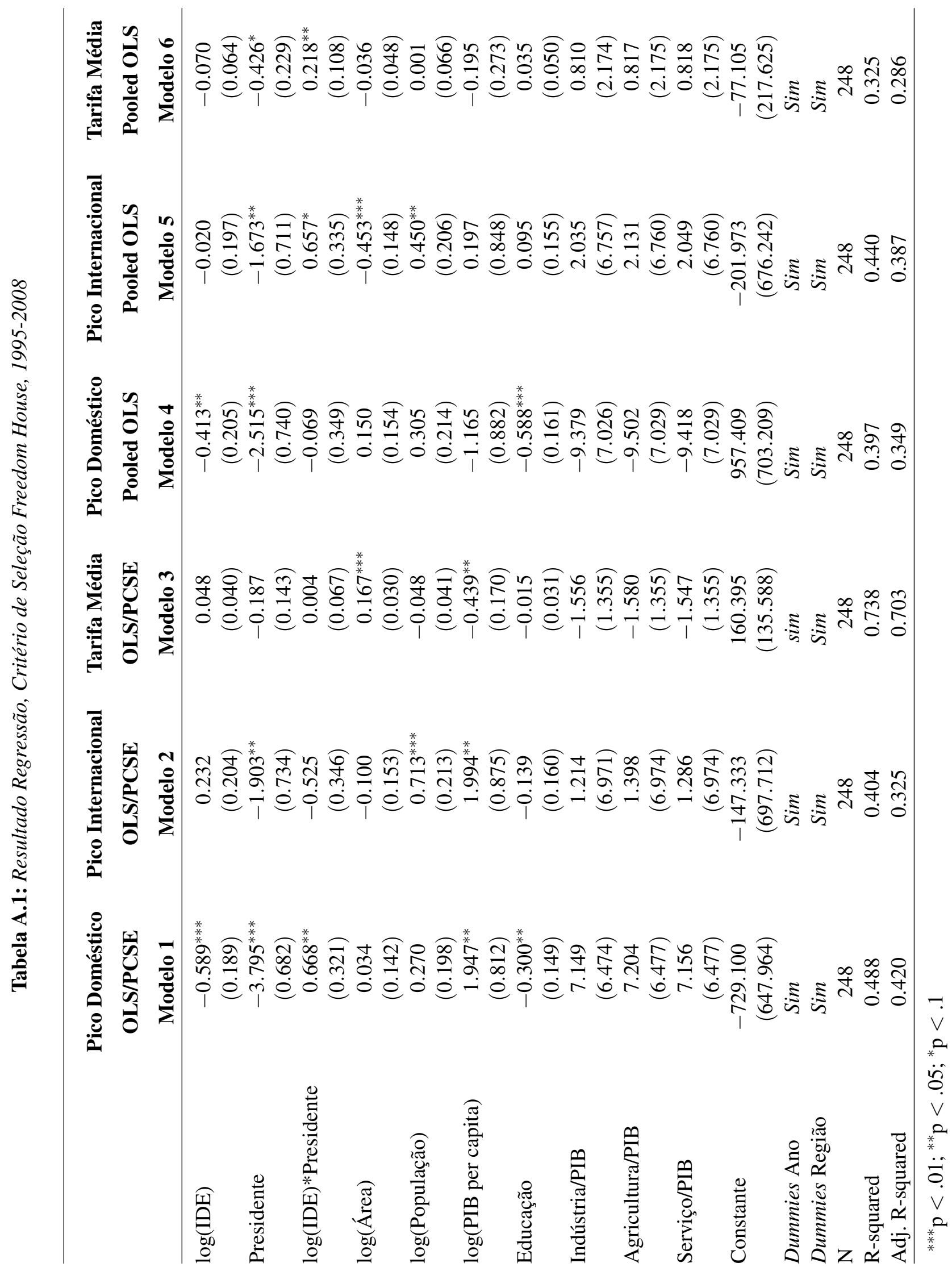




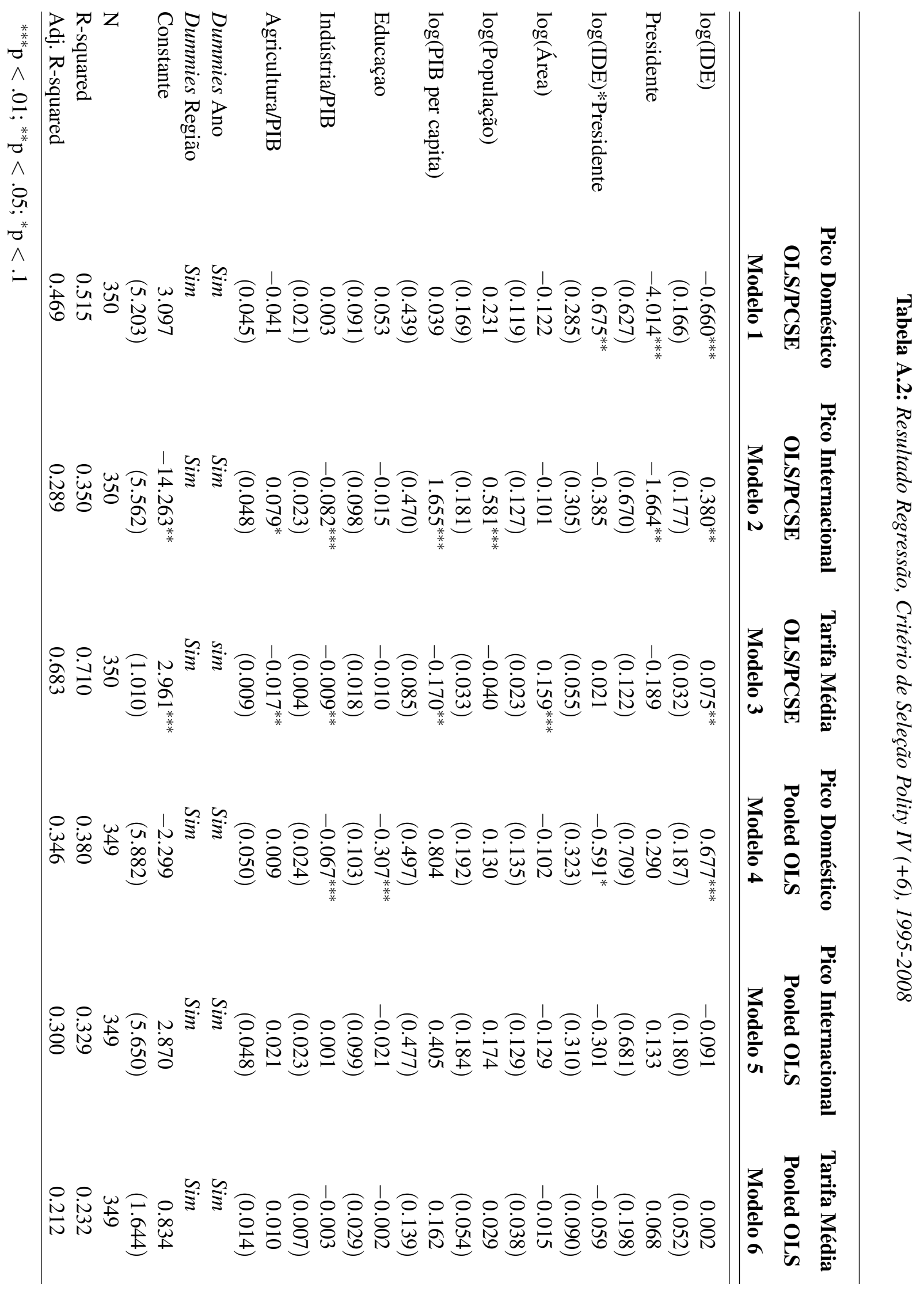




\section{Referências Bibliográficas}

Ardelean, Adina and Carolyn L. Evans. 2013. "Electoral systems and protectionism: an industry-level analysis." Canadian Journal of Economics/Revue canadienne d'économique 46(2):725-764.

URL: http://dx.doi.org/10.1111/caje.12030 40

Bailey, Delia and Jonathan N Katz. 2011. "Implementing Panel-Corrected Standard Errors in R: The pcse Package.” Journal of Statistical Software 42(c01). 82

Baldwin, Robert E. 1989. "The Political Economy of Trade Policy." The Journal of Economic Perspectives 3(4):119-135. 35

Bawn, Kathleen and Frances Rosenbluth. 2006. "Short versus long coalitions: electoral accountability and the size of the public sector." American Journal of Political Science 50(2):251-265. 32

Beck, Nathaniel. 2001a. “Time-series-cross-section Data.” Statistica Neerlandica 55(2):111133. 81

Beck, Nathaniel. 2001b. "Time-series-cross-section data: What have we learned in the past few years?" Annual review of political science 4(1):271-293. 81, 82

Beck, Nathaniel and Jonathan N Katz. 1995. "What to do (and not to do) with time-series cross-section data." American political science review pp. 634-647. 81, 82

Beck, Nathaniel and Jonathan N Katz. 1996. "Nuisance vs. substance: Specifying and estimating time-series-cross-section models." Political analysis 6(1):1-36. 81

Beck, Nathaniel and Jonathan N Katz. 2011. "Modeling dynamics in time-series-cross-section political economy data." Annual Review of Political Science 14:331-352. 81

Beck, Nathaniel, Jonathan N Katz and Richard Tucker. 1998. "Taking time seriously: Timeseries-cross-section analysis with a binary dependent variable." American Journal of Political Science 42(4):1260-1288. 81 
Blais, André and Agnieszka Dobrzynska. 1998. "Turnout in electoral democracies." European Journal of Political Research 33(2):239-261. 30

Blais, André and R Kenneth Carty. 1990. "Does proportional representation foster voter turnout?" European Journal of Political Research 18(2):167-181. 30

Borisyuk, Galina, Colin Rallings and Michael Thrasher. 2004. "Selecting Indexes of Electoral Proportionality: General Properties and Relationships." Quality \& Quantity 38(1):51-74. 72

Carey, J.M. and M.S. Shugart. 1995. "Incentives to Cultivate a Personal Vote: a Rank Ordering of Electoral Formulas." Electoral Studies 14(4):417-439. 32, 39

Carey, John M and Simon Hix. 2011. “The Electoral Sweet Spot: Low-Magnitude Proportional Electoral Systems." American Journal of Political Science 55(2):383-397. 83

Carey, John and Simon Hix. 2013. "Between Science and Engineering: Reflections on the APSA Presidential Task Force on Political Science, Electoral Rules, and Democratic Governance." Perspectives on Politics 11:820-824. 30

CEBRAP. 2010. "Banco de Dados de Votações Nominais para a Câmara dos Deputados e Senado (1989-2010).”. 51

Chang, Eric C. C., Mark Andreas Kayser, Drew A. Linzer and Ronald Rogowski. 2010. Electoral Systems and the Balance of Consumer-Producer Power. Cambridge University Press. $70,71,72,73,74,92$

Cheibub, Jose Antonio, Jennifer Gandhi and James Raymond Vreeland. 2009. "Democracy and dictatorship revisited." Public Choice 143(1-2):67-101. 85

Cingranelli, David and Mikhail Filippov. 2010. "Electoral Rules and Incentives to Protect Human Rights.” The Journal of Politics 72(01):243-257. 30

Cohen, Frank S. 1997. "Proportional versus majoritarian ethnic conflict management in democracies." Comparative Political Studies 30(5):607-630. 30

Destler, I. M. 2005. American Trade Politics, Fourth Edition. 4 ed. Institute for International Economics. 35, 36, 88

Ehrlich, Sean. 2009. "Constituency Size and Support for Trade Liberalization: An Analysis of Foreign Economic Policy Preferences in Congress." Foreign Policy Analysis 5(3):215-232. $37,46,47,48,68$

Ehrlich, Sean D. 2007. “Access to Protection: Domestic Institutions and Trade Policy in Democracies.” International Organization 61(03):571-605. 41, 43, 88 
Ehrlich, Sean D. 2011. Access points: an institutional theory of policy bias and policy complexity. New York: Oxford University Press. 41, 43, 88

Eichengreen, Barry and David Leblang. 2008. "Democracy and Globalization.” Economics \& Politics 20(3):289-334. 29

Evans, Carolyn L. 2009. “A Protectionist Bias in Majoritarian Politics: an Empirical Investigation." Economics and Politics 21(2):278-307. 40

Evans, Carolyn L and Nicholas Obradovich. 2011. "Electoral Systems and the Protection of Critical Goods.”. 40

Fabrizio, Stefania and Ashoka Mody. 2006. "Can budget institutions counteract political indiscipline?" Economic Policy 21(48):689-739. 32

Feliú, Pedro Ribeiro. 2012. Comportamento legislativo e política externa na América Latina Tese de doutorado Universidade de São Paulo. Tese de Doutorado.

URL: http://www.teses.usp.br/teses/disponiveis/8/8131/tde-13032013-110702/49, 61

Figueiredo, Argelina and Fernando Limongi. 1999. Executivo e Legislativo na Nova Ordem Constitucional. Rio de Janeiro/ Brasil: Editora FGV. 59

Frye, Timothy and Edward D. Mansfield. 2004. "Timing is Everything." Comparative Political Studies 37(4):371 -398. 29

Funk, Patricia and Christina Gathmann. 2010. "How do electoral systems affect fiscal policy? Evidence from state and local governments, 1890 to 2005.”. 32

Gagliarducci, Stefano, Tommaso Nannicini and Paolo Naticchionia. 2011. "Electoral Rules and Politicians' Behavior: A Micro Test." American Economic Journal: Economic Policy 3(3):144-174.

URL: http://www.ingentaconnect.com/content/aea/aejep/2011/00000003/00000003/art00006 32

Gakidou, Emmanuela, Krycia Cowling, Rafael Lozano and Christopher JL Murray. 2010. “Increased educational attainment and its effect on child mortality in 175 countries between 1970 and 2009: a systematic analysis." The Lancet 376(9745):959-974. 83

Gallagher, Michael. 1991. "Proportionality, disproportionality and electoral systems." Electoral Studies 10(1):33-51. 74

Gandrud, Christopher. 2012. "Two Sword Lengths: Losers' Consent and Violence in National Legislatures." SSRN eLibrary . 83 
Gilligan, Michael J. 1997. Empowering Exporters: Reciprocity, Delegation, and Collective Action in American Trade Policy. University of Michigan Press. 35

Gilpin, Robert. 1983. War and Change in World Politics. Cambridge University Press. 28

Hadenius, Axel and Jan Teorell. 2005. "Cultural and economic prerequisites of democracy: Reassessing recent evidence." Studies in Comparative International Development (SCID) 39(4):87-106. 83

Haggard, Stephan and Robert R. Kaufman. 1995. The Political Economy of Democratic Transitions. Princeton University Press. 37

Hankla, Charles R. 2006. "Party Strength and International Trade." Comparative Political Studies 39(9):1133 -1156. 36, 37, 39, 43

Karol, David. 2007. "Does Constituency Size Affect Elected Officials' Trade Policy Preferences?" Journal of Politics 69(2):483-494. 37, 46, 48, 68

Keefer, Philip. 2010. "Database of Political Institutions (DPI).”.

URL: http://go.worldbank.org/2EAGGLRZ40 74

Keohane, Robert O. 1984. After Hegemony: Cooperation and Discord in the World Political Economy. 1st princeton classic ed ed. Princeton University Press. 29

Krasner, Stephen D. 1976. "State Power and the Structure of International Trade." World Politics 28(3):317-347. 28

Kunicová, Jana and Susan Rose-Ackerman. 2005. "Electoral Rules and Constitutional Structures as Constraints on Corruption." British Journal of Political Science 35(04):573-606. 30

Lake, David. 2002. Progress in International Relations: Beyond Paradigms in the Study of Institutions. In Realism and Institutionalism in International Studies, ed. Frank Harvey and Michael Brecher. University of Michigan Press. 28

Lake, David A. 2008. International Political Economy: A Maturing Interdiscipline. In The Oxford Handbook of Political Economy, ed. Donald A. Ritchie and Barry R. Weingast. Oxford University Press. 28

Lake, David A. 2009. "Open economy politics: A critical review." The Review of International Organizations 4(3):219-244. 28

Lijphart, Arend. 1990. "The Political Consequences of Electoral Laws, 1945-85." The American Political Science Review 84(2):481. 72 
Linzer, Drew A. and Ronald L. Rogowski. 2008. "Lower Prices: The Impact of Majoritarian Systems in Democracies Around the World.” The Journal of Politics 70(01). 70

Lohmann, Susanne and Sharyn O'Halloran. 1994. "Divided Government and U.S. Trade Policy: Theory and Evidence." International Organization 48(4). 35, 36

Mansfield, Edward D., Helen V. Milner and B. Peter Rosendorff. 2002. "Why Democracies Cooperate More: Electoral Control and International Trade Agreements." International Organization 56(3):477-513. 29

Mansfield, Edward D. and Marc L. Busch. 1995. "The Political Economy of Nontariff Barriers: A Cross-National Analysis.” International Organization 49(04):723-749. 36, 40, 78

Mansfield, Edward D. Milner, Helen V. and B. Peter Rosendorff. 2000. "Free to Trade: Democracies, Autocracies, and International Trade." The American Political Science Review 94(2):305-321. 29

Matland, Richard E and Donley T Studlar. 1996. "The contagion of women candidates in single-member district and proportional representation electoral systems: Canada and Norway." The Journal of Politics 58(03):707-733. 30

McGillivray, Fiona. 1997. "Party Discipline as a Determinant of the Endogenous Formation of Tariffs." American Journal of Political Science 41(2):584-607. 36

McGillivray, Fiona. 2004. Privileging Industry: The Comparative Politics of Trade and Industrial Policy. Princeton University Press. 34, 41

Milesi-Ferretti, Gian Maria, Roberto Perotti and Massimo Rostagno. 2002. "Electoral systems and public spending." The Quarterly Journal of Economics 117(2):609-657. 33

Mukherjee, Bumba, Dale L. Smith and Quan Li. 2009. "Labor (Im)mobility and the Politics of Trade Protection in Majoritarian Democracies." The Journal of Politics 71:291-308. 41

Nielson, Daniel L. 2003. "Supplying Trade Reform: Political Institutions and Liberalization in Middle-Income Presidential Democracies." American Journal of Political Science 47(3):470-491. 37, 38, 39, 88

Park, Jong Hee and Nathan Jensen. 2007. "Electoral Competition and Agricultural Support in OECD Countries." American Journal of Political Science 51(2):314-329. 43

Peltzman, Sam. 1976. “Toward a more general theory of regulation.”. 70

Peltzman, Sam. 1989. "The economic theory of regulation after a decade of deregulation." Brookings Papers on Economic Activity. Microeconomics 1989:1-59. 70 
Persson, Torsten. 2002. “Do Political Institutions Shape Economic Policy?” Econometrica 70(3):883-905.

URL: http://dx.doi.org/10.1111/1468-0262.00313 33

Persson, Torsten and Guido Tabellini. 1999. "The size and scope of government:: Comparative politics with rational politicians." European Economic Review 43(4):699-735. 32

Persson, Torsten and Guido Tabellini. 2005. The Economic Effects of Constitutions. The MIT Press. 33

Persson, Torsten, Guido Tabellini and Francesco Trebbi. 2003. "Electoral Rules and Corruption." Journal of the European Economic Association 1(4):958-989. 30

Power, Timothy J. and Cesar Zucco. 2012. "Elite Preferences in a Consolidating Democracy: The Brazilian Legislative Surveys, 1990-2009." Latin American Politics and Society 54(4):127. 55

Przeworski, Adam, Michael E. Alvarez, José Antonio Cheibub and Fernando Limongi. 2000. Democracy and Development: Political Institutions and Well-Being in the World, 1950-1990. 1 ed. Cambridge University Press. 84, 85

Rickard, Stephanie J. 2010. "Democratic differences: Electoral institutions and compliance with GATT/WTO agreements.” European Journal of International Relations 16(4):711 729. 39

Rickard, Stephanie J. 2012. "A Non-Tariff Protectionist Bias in Majoritarian Politics: Government Subsidies and Electoral Institutions1.” International Studies Quarterly 56(4):777-785. 39

Rogowski, Ronald. 1987. "Trade and the Variety of Democratic Institutions." International Organization 41(2):203-223. 34, 35, 36, 38

Rogowski, Ronald, Eric C. C. Chang and Mark Andreas Kayser. 2008. "Electoral Systems and Real Prices: Panel Evidence for the OECD Countries, 1970-2000.” British Journal of Political Science 38(4):739-751. 70

Rogowski, Ronald and Mark Andreas Kayser. 2002. "Majoritarian Electoral Systems and Consumer Power: Price-Level Evidence from the OECD Countries." American Journal of Political Science 46(3):526-539. 70

Schattschneider, E. E. 1935. Politics, pressures and the tariff;: A study offree private enterprise in pressure politics, as shown in the 1929-1930 revision of the tariff,. Prentice-Hall. 35, 36, 88 
Scheiner, Ethan and Robert G. Moser. 2012. Electoral Systems and Political Context: How the Effects of Rules Vary Across New and Established Democracies. Cambridge: Cambridge University Press.

URL: http://bit.ly/11wZoUi 76

Stigler, George J. 1971. "The theory of economic regulation.” The Bell journal of economics and management science pp. 3-21. 70

Taagepera, Rein. 1986. "Reformulating the Cube Law for Proportional Representation Elections." The American Political Science Review 80(2):489. 72

Taagepera, Rein and Bernard Grofman. 2003. "Mapping the Indices of Seats-Votes Disproportionality and Inter-Election Volatility." Party Politics 9(6):659-677. 72

Tavares, José. 2008. “Trade, Factor Proportions, and Political Rights." The Review of Economics and Statistics 90(1):163-168. 29

VanGrasstek, Craig. 2001. The Political Economy of Residual Protection in the Trade Regime of the United States of America: A Report Prepared for the United Nations Conference on Trade and Development. UN. 88

Weinberg, Joe. 2012. "Do Majoritarian Electoral Systems Favor Consumers: Identifying CrossNational Consumer Bias1.” International Studies Quarterly 56(4):820-826. 73, 92

Weingast, Barry R., Judith. Goldstein and Michael A. Bailey. 1997. "The Institutional Roots of American Trade Policy: Politics, Coalitions, and International Trade." World Politics 49(3):309-338. 35

Wintrobe, Ronald. 2000. The Political Economy of Dictatorship. 1 ed. Cambridge University Press. 29

World Bank, World Bank. 2012a. "Trade Analysis and Information System (TRAINS) and World Integrated Trade Solution) (TWITS).” http://wits.worldbank.org/wits.

URL: http://wits.worldbank.org/wits 83

World Bank, World Bank. 2012b. "The World dataBank (World Development Indicadors.”.

URL: http://data.worldbank.org/ 83

WTO, World Trade Organization. $2012 . \quad$ "Glossary." http://www.wto.org/english/thewto_e/glossary_e/tariff_peaks_e.htm. 77 